\title{
Figura: Presença e Permanência
}

Paulo Camillo de Oliveira Penna

Projeto artístico equivalente à Dissertação de Mestrado Linha de pesquisa em Poéticas Visuais

Departamento de Artes Plásticas da Escola de Comunicações e Artes Universidade de São Paulo

Orientador: Prof. Dr. Marco Francesco Buti 

Abstract

Depoimento

Figuras

Retratos

Relação de obras 
A figura humana, em sua construção pelo desenho, constitui a questão central deste projeto, em que apresento uma obra gráfica e um depoimento sobre meu processo de trabalho.

A figura se manifesta concretamente no desenho, em distintas práticas e no movimento entre estas e suas relações com os referentes, de observação, de memória, de emoção, de pensamento. Neste movimento, o desenho se apresenta como lugar aberto à constituição da figura, como presença e possibilidade do devir.

O projeto de mestrado é, neste processo, um lugar para o aprofundamento deste trabalho, através da discussão, da reflexão, da crítica e sobretudo do enfrentamento dos problemas que se apresentam no trabalho, em seus respectivos meios, da gravura e do desenho.

Seu objeto é constituído por este trabalho gráfico, que será exposto, e pela sua documentação, somada a um depoimento, e se organiza em dois grupos: Figuras e Retratos. 
The human figure, constructed by the drawing, is the main subject of this project, where I present a graphic work and a statement of my work's progress.

The figure founds a concrete manifestation at the drawing, by different practices and on a movement towards their references of observation, memory, emotion and thought. At this movement, the drawing presents itself as an opened place to the constitution of the figure, as a presence and as a possibility of a becoming.

At this process, the project of a master degree is an occasion to go deeper into this work, by the discussion, the reflection, the criticism and above all by facing the problems founded during the work of engraving, printing and drawing, in their respective Medias.

Its object consists of this graphic work, that will be exhibited, and of its documentation added to a statement. It is organized in two groups: Figures and Portraits. 
As indagações e reflexões que permeiam este depoimento se inauguram no interior das práticas e dos processos construtivos gráficos que enfrento.

Um depoimento não dá conta de todas as questões inerentes a um processo de trabalho, dos pensamentos, das decisões tomadas, das operações materiais. Pode elucidar em seu conjunto as direções que o trabalho toma, os caminhos percorridos, e refletir sobre possíveis desdobramentos. Estas operações permanecem abertas, e em determinada medida, irredutíveis a um discurso ou relato. O relato não as contém, mas contempla. Importante notar que este trabalho não é constituído de uma única direção, mas de feixes que se agrupam, se cruzam, se distanciam, se movem conjuntamente.

As imagens presentes neste depoimento estão numeradas, e nos trechos nos quais me refiro a alguma imagem, sua numeração aparece ao lado. Ao final há uma ficha técnica com suas respectivas informações. 
Figuras 
Entre 1999 e 2006 fiz uma série de trabalhos que tratam da figura humana, em que o desenho se manifesta como entendimento e construção da forma por meio da qual a figura se faz presente. Nestes trabalhos, empreguei distintos meios, sobretudo a xilogravura e desenho a lápis, pena, carvão e pincel. 
Uma das práticas presentes neste trabalho é a do desenho de observação de pessoas, composta por desenhos de anotação, feitos a lápis, pena ou pincel em cadernos de desenho, constituindo grupos em que procuro captar a forma destas pessoas, em diferentes situações e posições.

Os desenhos são realizados em séries, em lugares que habito, ou na rua, em meus percursos pela cidade e se organizam em conjuntos e em fluxos. Desenho observando as pessoas a minha volta, sua posição, seus gestos, seus movimentos, em apontamentos. De conjuntos de desenhos similares, feitos em seqüência ou alternadamente, emerge uma proposição sintética da forma, construída com economia de meios, em que procuro empregar apenas as linhas que julgo necessárias para a sua apreensão. A eleição desta prática de desenho também se dá pelo anseio de clareza na manifestação da figura humana, o que me exige precisão e presteza. Este anseio é recorrente ao longo de meu trabalho, e é um dos móveis no cotejamento entre distintas práticas, em que a figura se faz presente em cada manifestação, mas também neste movimento entre elas, como um desenho que percorre distintos meios e assume novas configurações. 

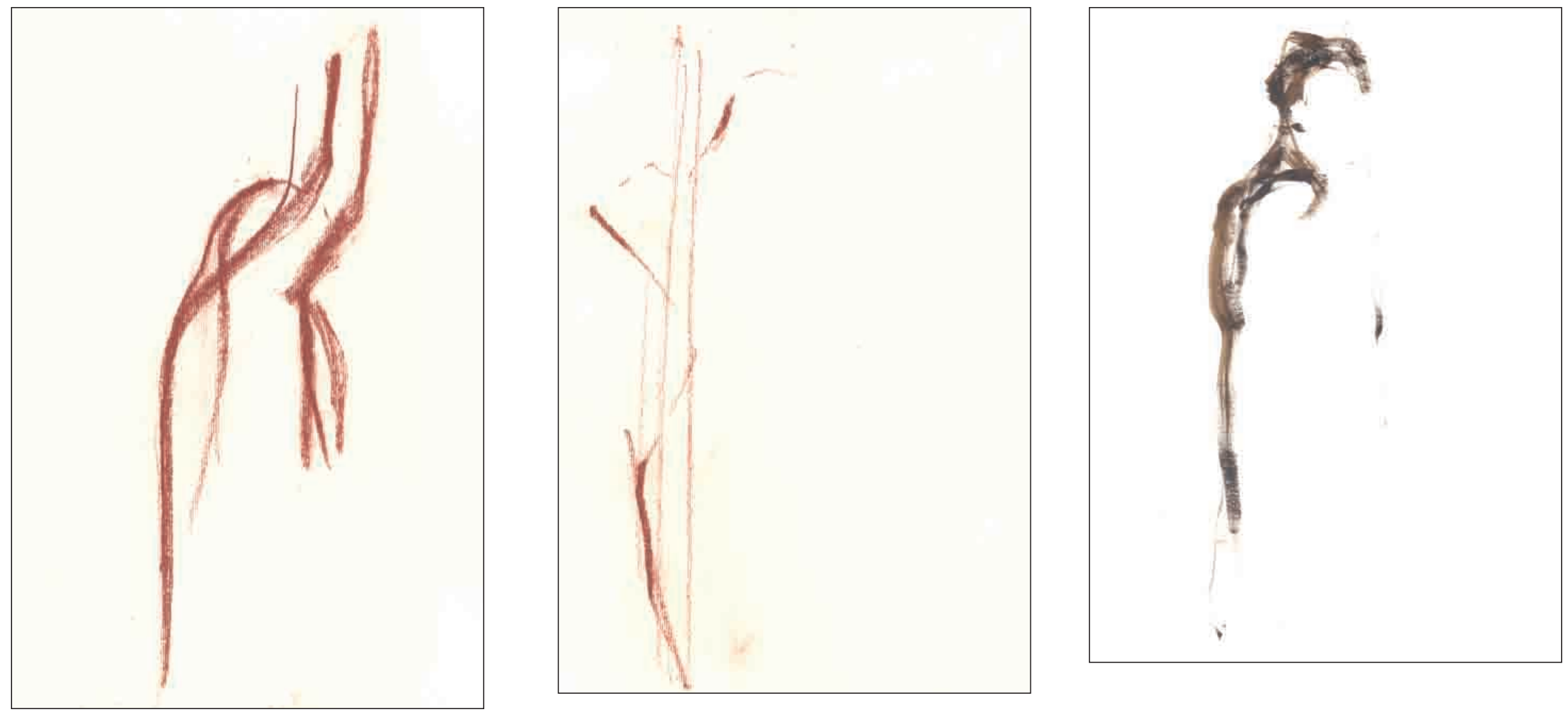
Outro meio empregado neste processo é a xilogravura, na qual trabalho de memória, na construção de formas que guardam e tornam presente a figura humana. Pelo desenho, no pensamento e construção, as xilogravuras dialogam com os desenhos de observação. A forma que emerge dos conjuntos de desenhos emerge também, como memória, nas xilogravuras, em um constante cotejamento entre as práticas, em que as distintas manifestações são tomadas como referência, em várias direções entre desenhos, xilogravuras, entre observação e memória. Neste processo, posso notar uma linha que migra de um trabalho para outro, e se transforma, em nova construção. Da mesma maneira, a figura se constitui em cada manifestação e neste constante movimento. Neste processo, observação e memória se justapõem e sobrepõem, na figura que porta o visto, o lembrado, o guardado, o desejado.

A figura se manifesta neste movimento, como devir, e em cada construção, em que se atualiza. Neste sentido, seus aspectos construtivos, em cada meio, lhe são intrínsecos. Em uma reflexão sobre a figura, nesta perspectiva, faço uma análise do processo de construção de algumas xilogravuras e desenhos. 


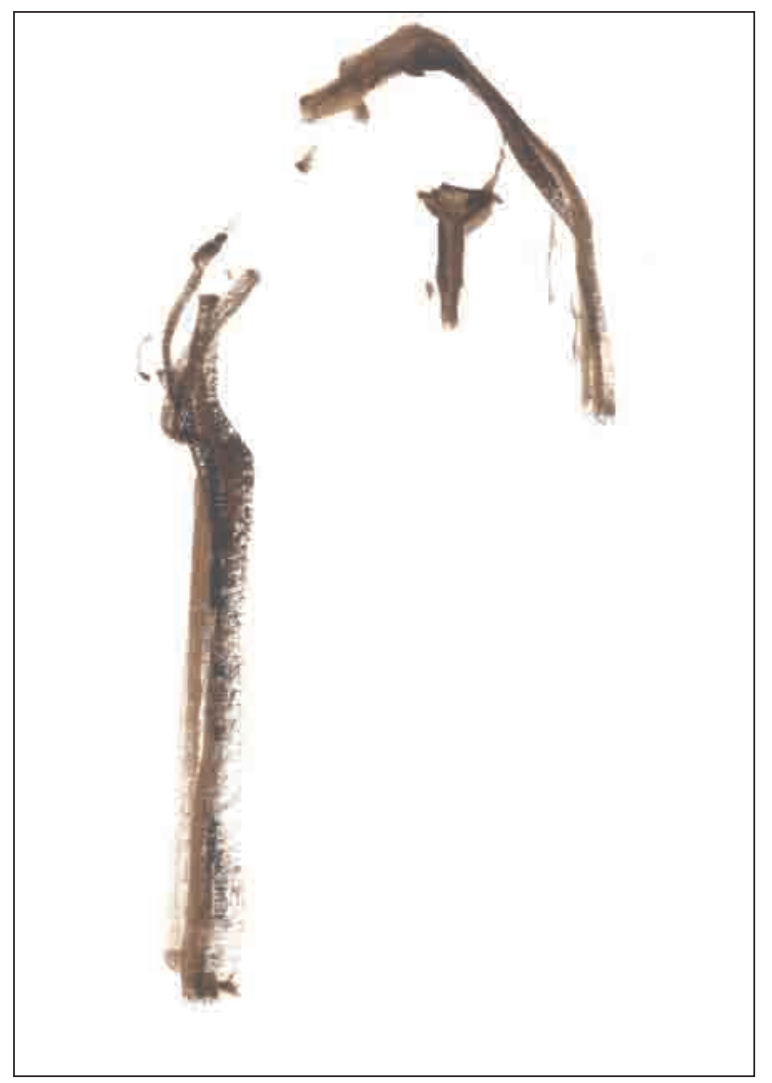

4. Sem título, 1999

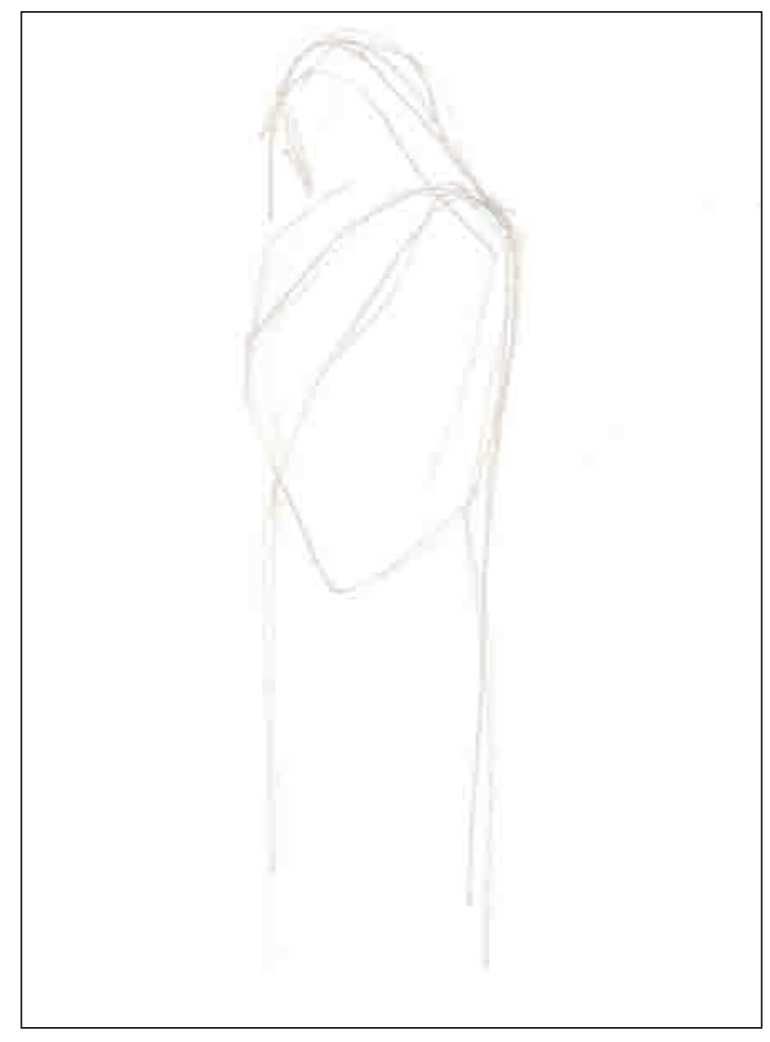

5. Sem título, 2001

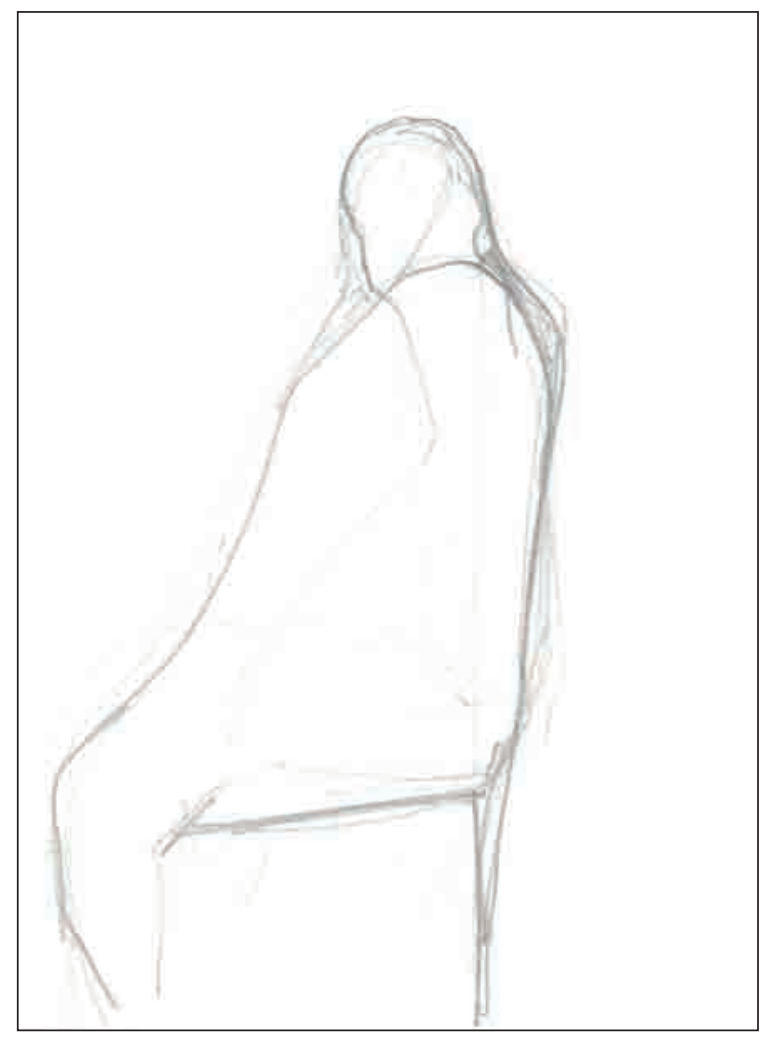

6. Sem título, 2001 
A linha, construída por meio de um corte na madeira é o princípio construtivo fundamental nesta xilogravura, assim como na série a qual pertence. Pelo corte gravo uma linha em encavo, que deixa em seu entorno uma superfície em relevo, e se institui em gestos contínuos que delineiam a figura. Esta linha pode ser modelada com uma nova incisão sobre o seu leito, tornando-a mais larga ou mais fina, mais profunda ou mais rasa ao longo de seu percurso, de acordo com o gesto e o ângulo de ataque da ferramenta no ato da gravação. Estas linhas impressas se manifestam como linhas luminosas, constituídas pelo gesto exercido na gravação com a faca e pela matéria da madeira, do papel e da tinta.

Luminosidade e evidência, luz que salta e projeta a figura na inflexão da linha.

Elegi para estas xilogravuras matrizes de tamanho próximo ao de uma pessoa. Estabeleci desta maneira uma escala para as figuras em que proponho uma relação direta entre as gravuras e as pessoas observadas, construída pelo desenho. 


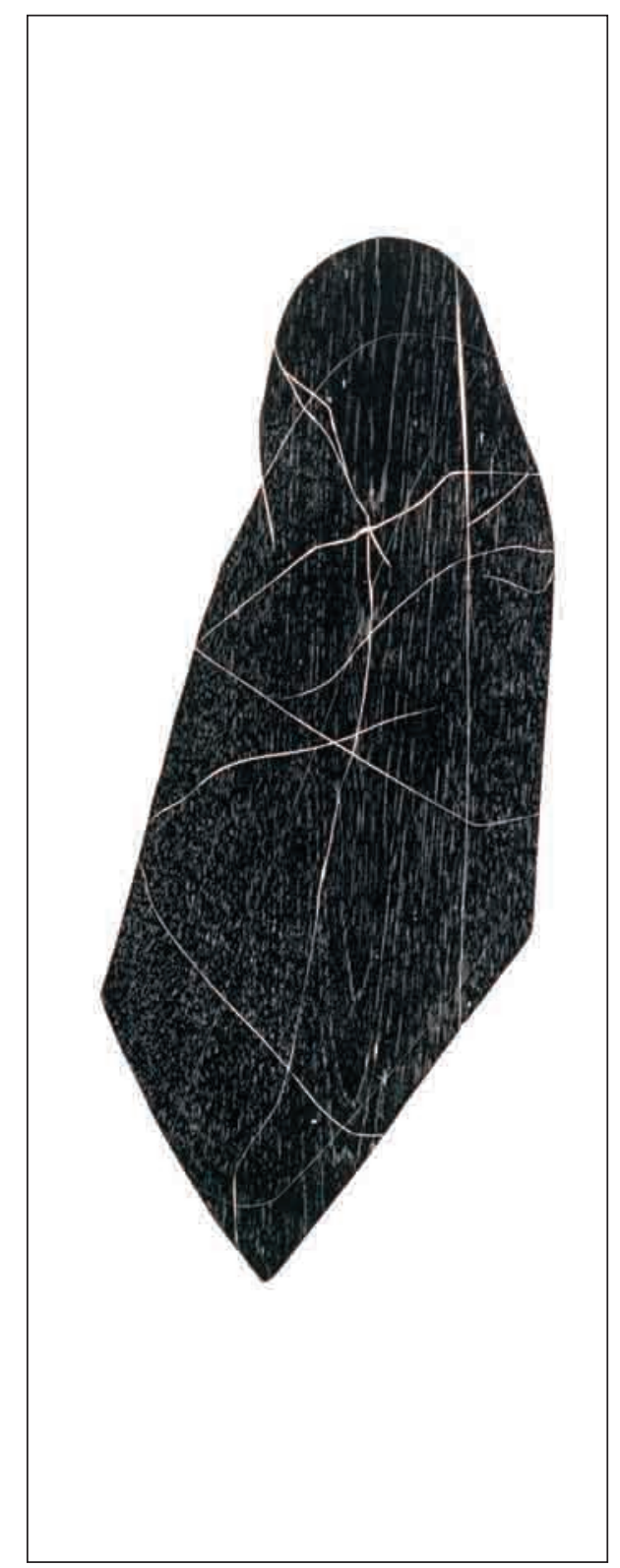


$\mathrm{Na}$ "Figura Recolhida", em seu primeiro estado, gravei três linhas, uma que a contorna e duas que a tensionam internamente, uma diagonal e outra perpendicular. Ao serem impressas, se manifestaram muito finas para contrastar com os veios da madeira. A 9 regravação se orientou pela necessidade de construir uma linha que se projete da superfície, e com ela projete a figura. Procurei dar o peso necessário às linhas para que em seus distintos valores modelassem a figura, conferissem a ela distintos espaços em relação a sua forma. Outra operação que efetuei foi do desbaste do entorno da figura, partindo da linha de contorno. Junto à definição dos valores das linhas luminosas, aprofundei as linhas de contorno para suportar o desbaste. Neste momento a figura se definiu pelo contraste entre a massa escura e seu entorno e pelas tensões desta com as linhas luminosas em seu interior. É possível distinguir a linha na margem e no interior da figura, mas em seus percursos, as linhas se movimentam do interior da figura para suas margens e destas para o centro. Este movimento é fundamental para se constituir a forma.

Neste processo, há um constante cotejamento entre grupos de trabalhos, em diferentes práticas, como outras xilogravuras, desenhos e monotipias. As decisões que tomo ao transformar uma gravura têm como orientação sua análise, o desejo e necessidade de transformá-la, e é comum colocá-la ao lado de outros trabalhos. Para decidir sobre uma nova incisão ou desbaste em uma gravura eu posso ter como referência linhas ou formas presentes nos desenhos de observação, assim como quando saio para desenhar trago para esta prática as inquietações de meu trabalho com a gravura. Da mesma forma, trabalho em mais de uma gravura ao mesmo tempo, e há um movimento em que formulações gráficas permanecem como conquistas, e se transformam constantemente. 

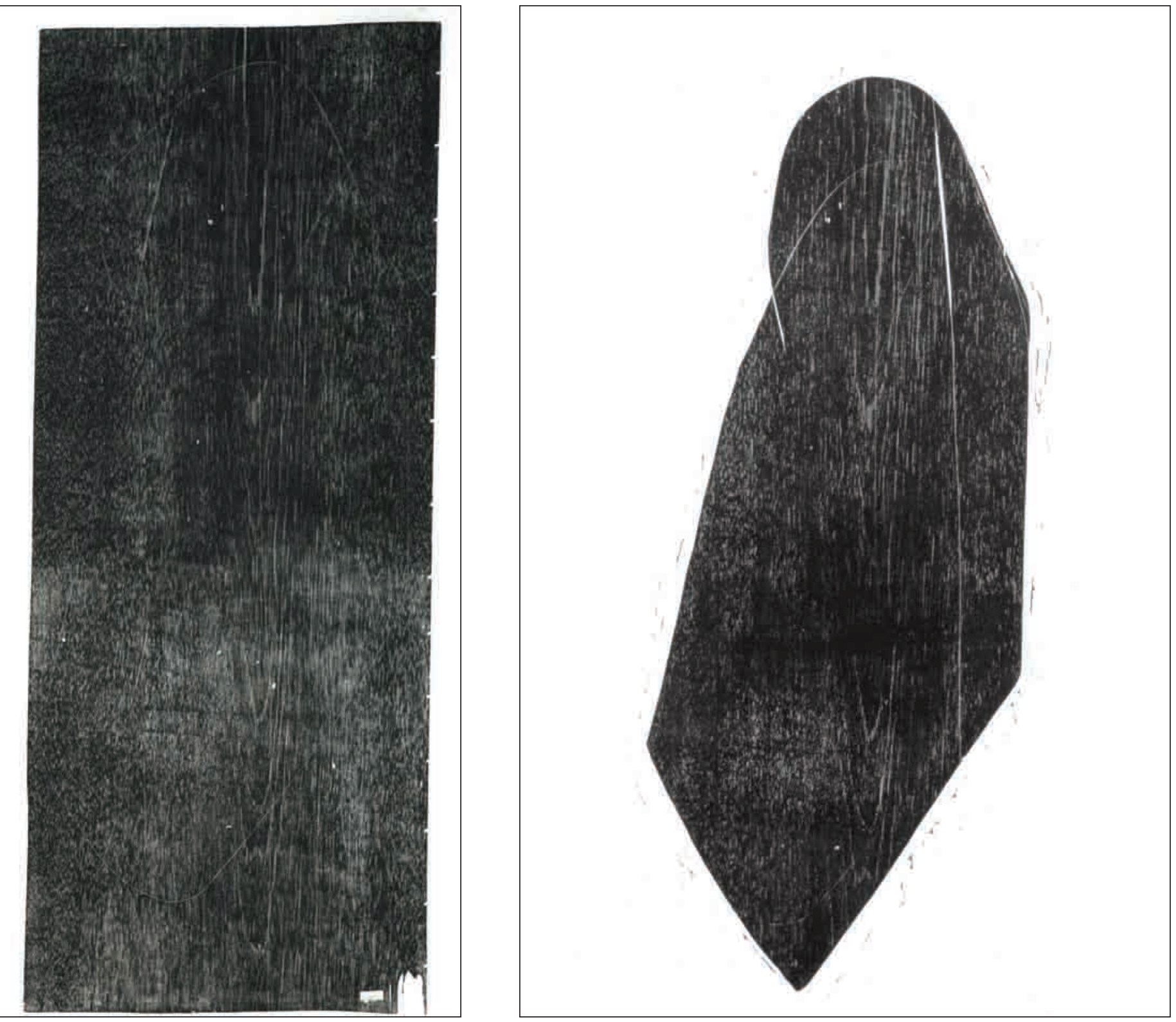

9. Figura Recolhida, 2000 
Ao comparar a "Figura Recolhida" com a "Figura em Repouso" é possível notar uma série de semelhanças. Na "Figura em Repouso", o processo construtivo foi similar. Das primeiras linhas, elegi algumas que nortearam o desbaste do entorno da figura. Comparando as duas figuras, se evidencia uma vertical que normalmente atravessa toda a forma, como uma linha de prumo. É uma linha fundamental para estabelecer a verticalidade da figura, e estabilizar e dimensionar a sua forma, visível no interior da figura ou em seu contorno. Nas duas gravuras as linhas são estruturais e se movimentam do interior para as margens. A figura assume sua forma pelas relações entre as linhas, que também a proporcionalizam, ao estabelecer medidas e distâncias, e ao indicar distintas partes do corpo.

Os primeiros estados da "Figura Recolhida" datam de 2000, e no ano passado decidi transformá-la. Ao observar a gravura em relação a outros trabalhos, percebi ou tive o desejo de que poderia ir adiante, outras manifestações poderiam estar presentes nesta figura. 


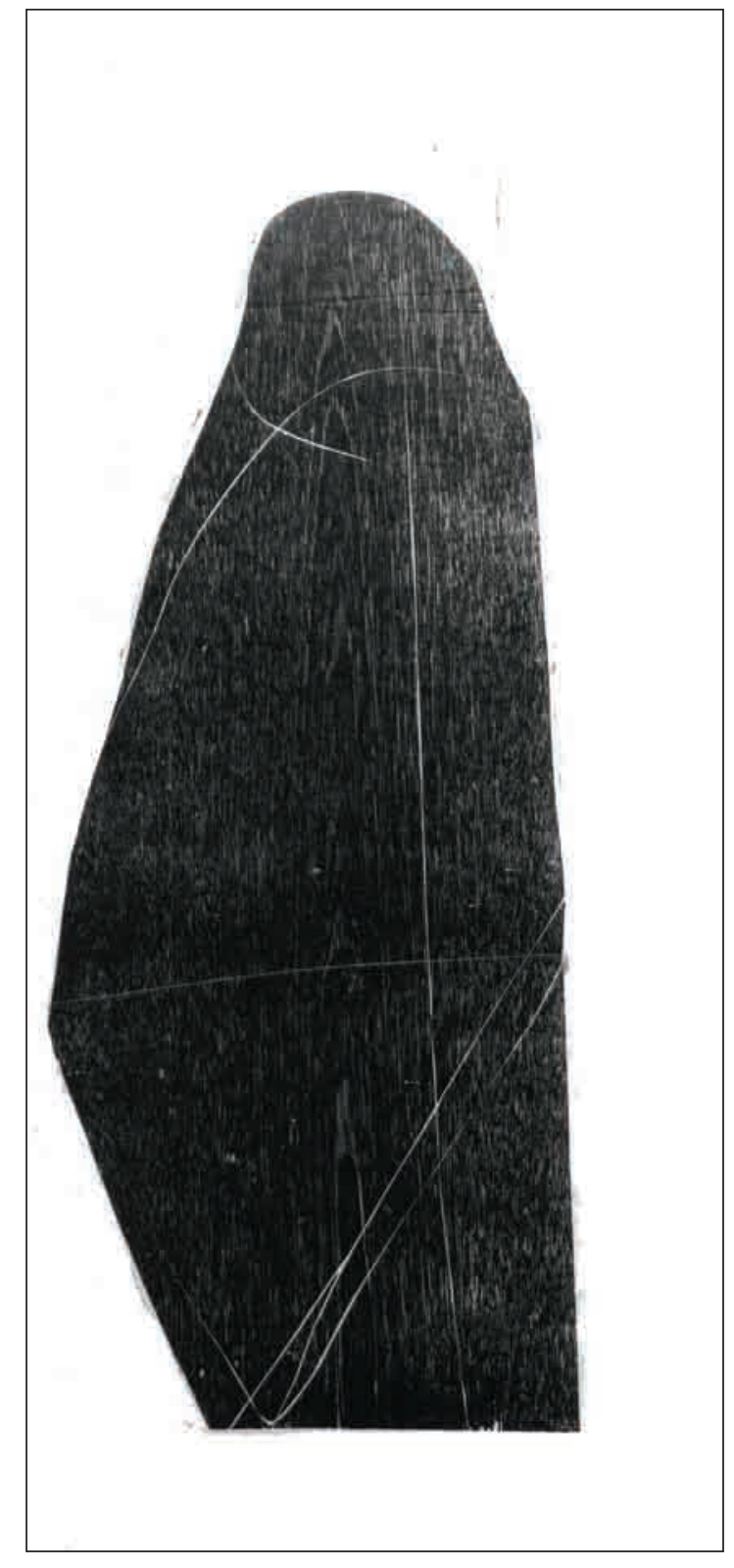


Neste processo, foi significativo o cotejamento com outras gravuras e com desenhos feitos neste período. Estes novos desenhos se somam aos anteriores, mas introduzem mudanças. Procurei um tamanho semelhante ao das xilogravuras e uma mesma relação de escala com as pessoas, seus referentes. Estes desenhos dialogam com as xilogravuras e participam das reflexões realizadas durante a transformação das matrizes e estampas. Alguns foram feitos de memória e tem como referência mais próxima as formas que construí nos cadernos e nas xilogravuras. Em seguida, passei a desenhar da observação e da memória de meu próprio corpo diante da folha de papel estendida verticalmente. Não usei espelho, mas observei minha postura diante dos desenhos, de pé ou agachado, de frente ou de perfil, e traçar linhas que pudessem percorrer e configurar o corpo nestas posições. Observei e propus linhas que percorressem o corpo internamente e se movessem em direção a seu contorno, como uma anatomia imaginária. As linhas não tentam descrever cada aspecto da anatomia do corpo, mas percorrê-lo interna e externamente, procurando aproximar sua estrutura a estrutura gráfica de uma figura, em nova proposição de síntese. 

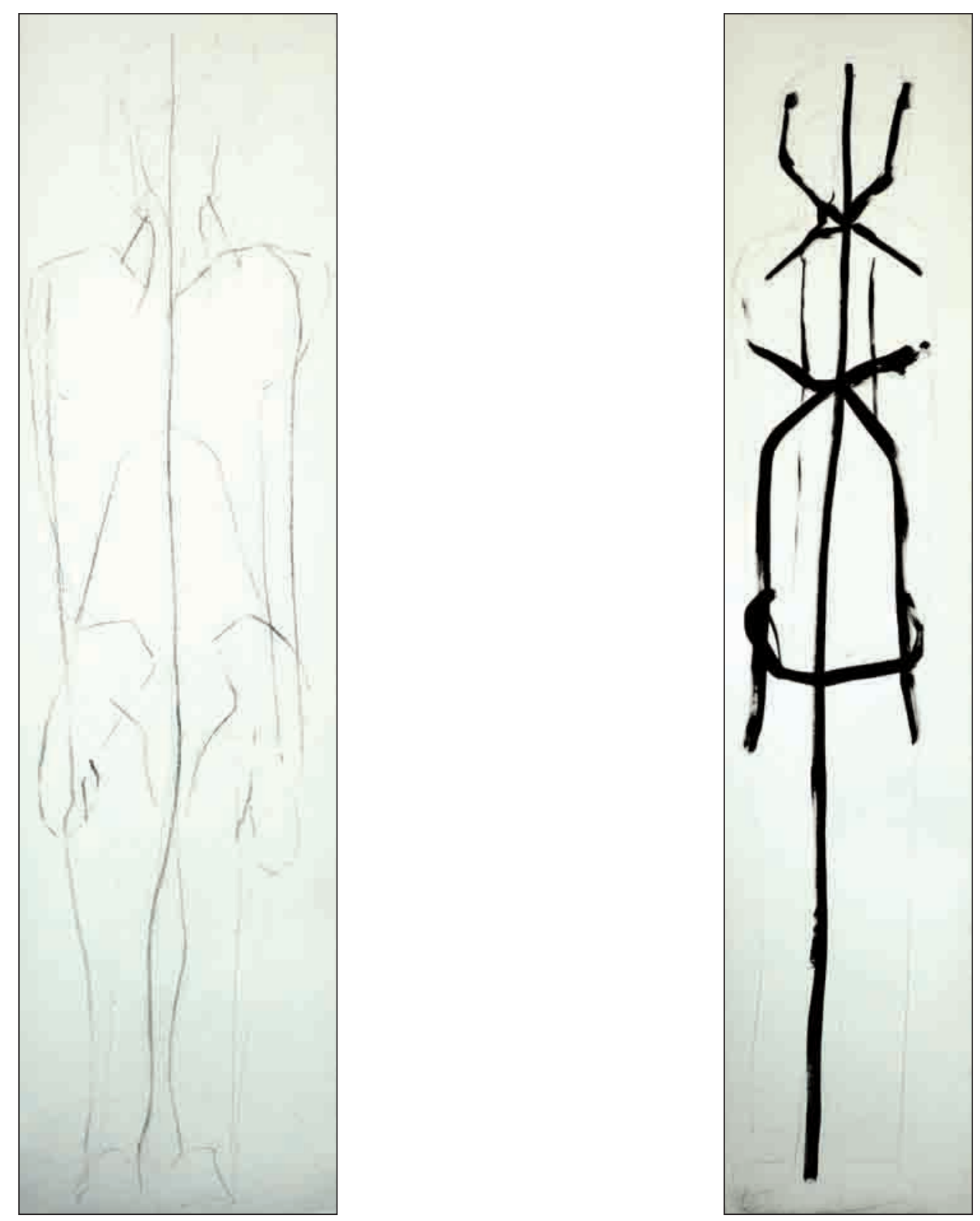

12. Sem título, 2005 
Nestes desenhos se fez necessário experimentar e alternar o uso dos materiais. Em alguns, empreguei lápis grafite duro que produz uma linha fina e cinza, vincando o papel, em outros, a pedra negra que produz um negro profundo, e em outros ainda o carvão, cuja linha é de um cinza denso, e por ser friável pode facilmente se aproximar de uma mancha. Por vezes sobrepus estes materiais, destacando e projetando distintamente algumas partes do desenho. Em alguns, sobrepus ao desenho a lápis um desenho a pincel, somando a mancha à linha. Os materiais empregados me permitiram a execução de traços contínuos e flexíveis. Pela inflexão da linha pude obter valores e modelar a forma. Empreguei também papéis de cores e formatos diferentes, e explorei as relações entre os traços e o campo do papel. Os desenhos se constituíram nesta investigação de estruturas e formas da figura humana por meio de construções gráficas. 

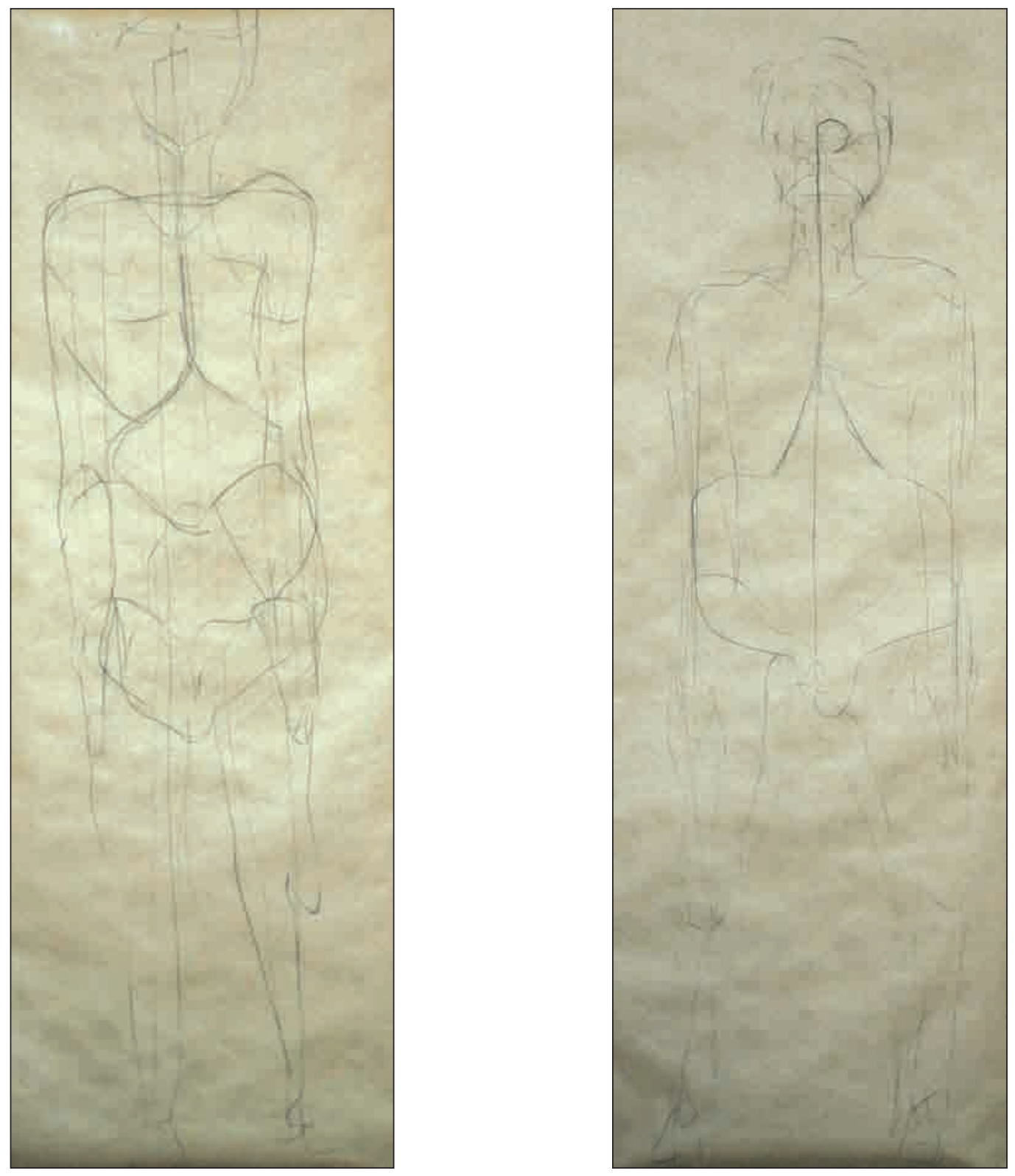

14. Sem título, 2005 
Ao retomar a "Figura Recolhida" fiz, simultaneamente à gravura, desenhos a carvão sobre folhas de tamanho próximo ao da matriz e tracei linhas pensando em uma posição de meu corpo que dialogasse com a forma gravada e que a tensionasse. 0 cotejamento com a prática da gravura esteve presente, na escala, na organização e construção das linhas, no entendimento da forma e sua espacialidade. Gravei novas linhas no interior da matriz, do que emergiu outra configuração, na qual algumas partes da figura, sobretudo o braço e a cabeça, se projetam da superfície escura. Ao observar esta gravura, e esta nova impressão junto à anterior, por vezes vejo uma nova figura, por vezes uma dentro da outra ou uma figura que se transforma em seu interior.

Um ato de figuração que se institui ao se colocar diante da figura, ao torná-la presente em sua evidência e concretude.

Uma proposição de síntese que encontra na linha a economia de meios da figuração. 

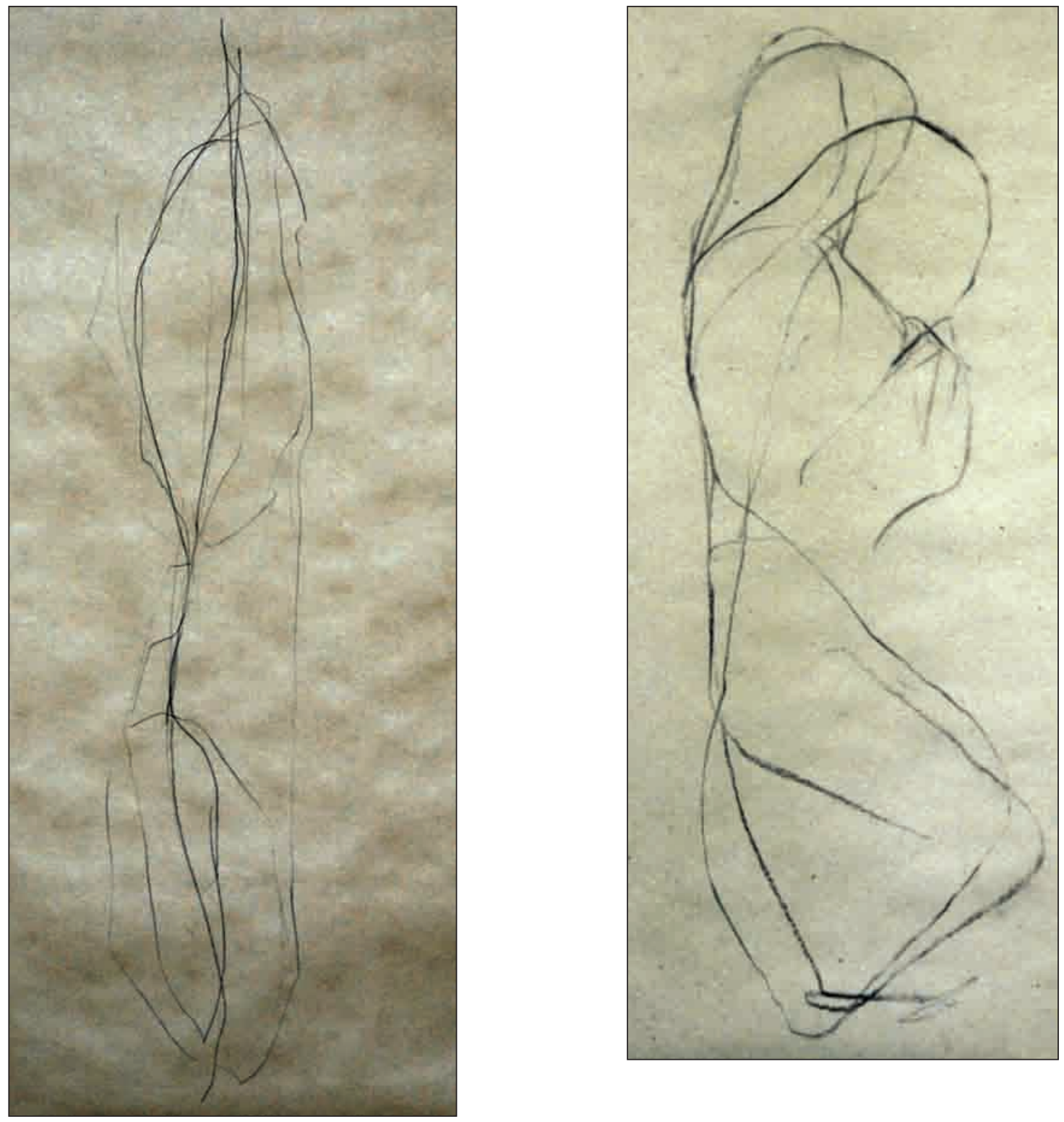

16. Sem título, 2005 
As xilogravuras "Figura Agachada" e "Duas Cabeças" foram gravadas entre 2000 e 2001 e regravadas em 2006. A "Figura Agachada" partiu de um polígono, e a relação entre sua forma e a de uma pessoa era muito distante. Ao retomá-la, procurei cotejar a sua forma com a anatomia do corpo humano, e assim como na figura recolhida, fiz ao mesmo tempo alguns desenhos sobre papel, de tamanhos aproximados ao da matriz, em que me agachei e tentei imaginar uma forma por meio de linhas que percorressem e designassem o meu corpo naquela posição. 

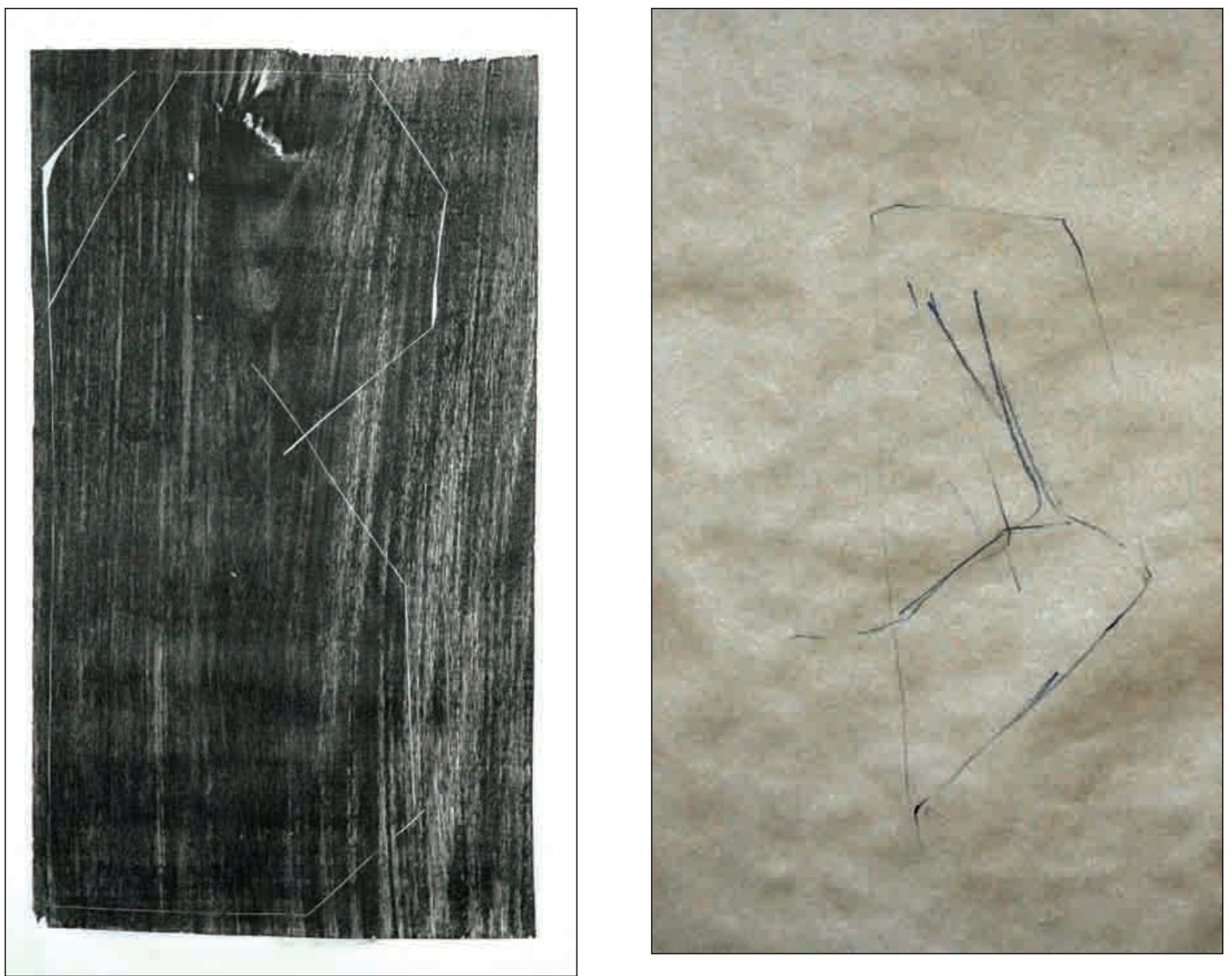

17. Figura Agachada, 2001

18. Sem título, 2005 
Ao trabalhar sobre a matriz, tracei linhas indicativas com giz claro que dialogassem com as linhas já gravadas. Em seguida gravei diretamente linhas que designassem partes do corpo como a cabeça, braço e perna e tomassem as linhas anteriores para esta nova configuração, em que surge uma figura agachada. 


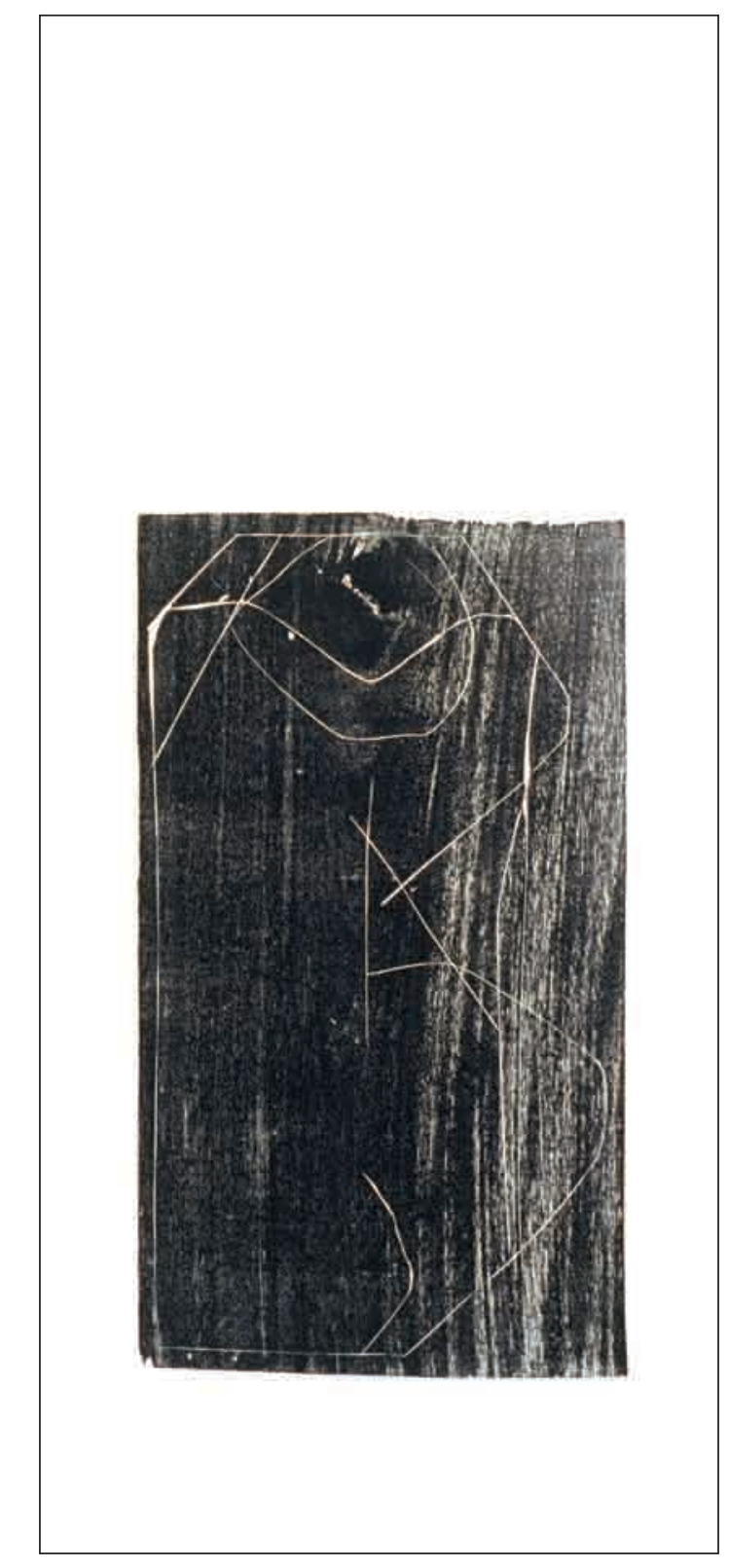


"Duas Cabeças" partiu de um arco, semelhante à forma de uma cabeça, porém muito maior que a de uma pessoa. Por um tempo, entre linhas e desbastes de formas em seu interior, a gravura oscilou entre uma arquitetura e a cabeça, ou uma cabeça dentro de um arco até se definir em duas cabeças, situadas em diagonal pela posição na matriz e por uma incisão comum que as cruza. 

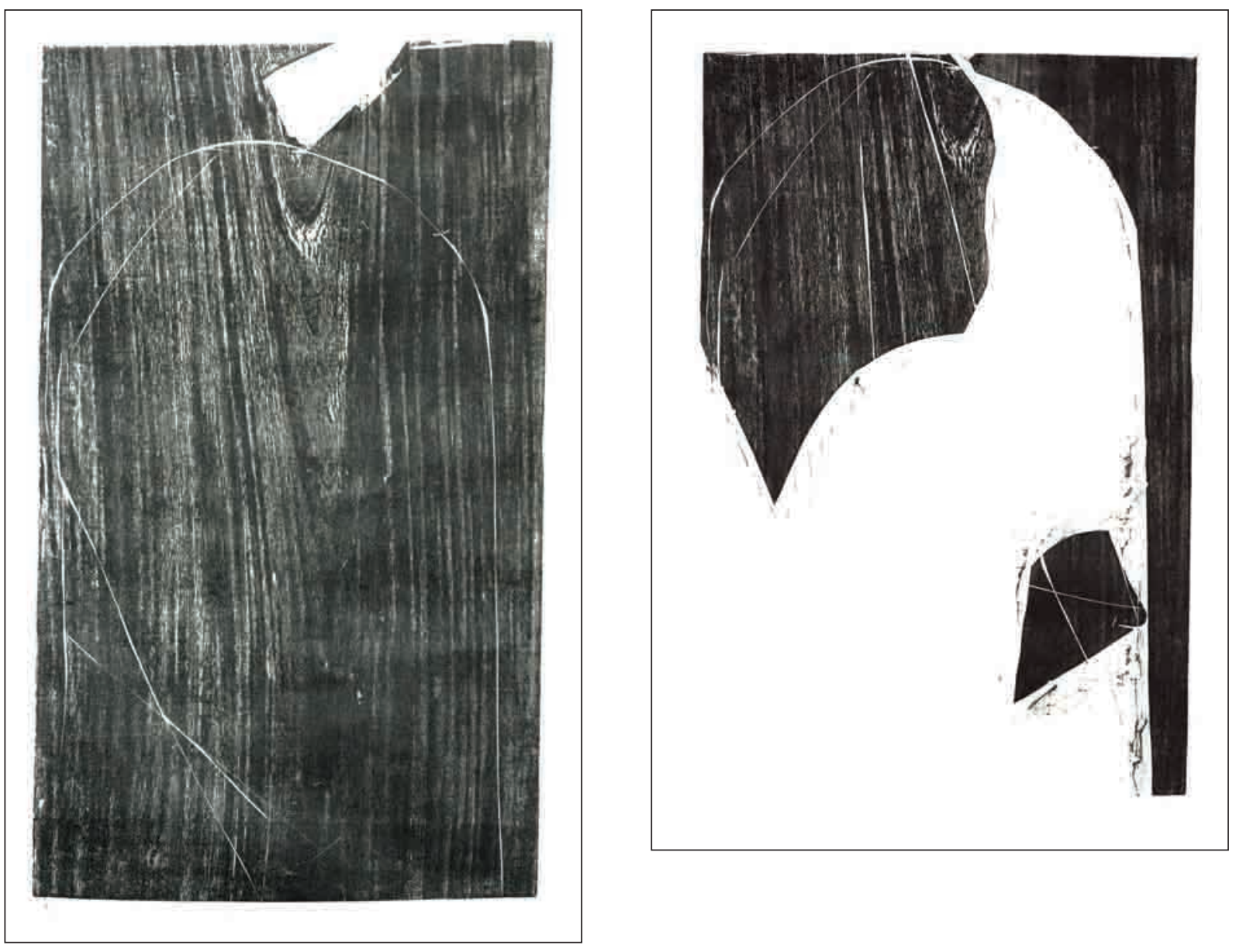

20. Duas Cabeças, 2001

21. Duas Cabeças, 2004 
Esta diagonal é visível no interior das duas massas, mas é perceptível também no espaço vazio, e estabelece a tensão necessária para que as duas cabeças constituam uma figura. A sua forma se apresenta então pelas relações entre massas, linhas e espaços vazios. Neste trabalho, em que a forma está aberta pela luz que invade o seu interior, é mais evidente a integração dos espaços vazios como constituintes da figura.

Em todas as gravuras, as tensões entre as massas e os vazios são estruturais de sua forma, mesmo quando estão apenas no seu entorno, e para tanto é necessário estabelecer, na impressão, um equilíbrio entre cheios e vazios. Comparando as gravuras, noto que em todas elas a forma é aberta, pelas linhas que atravessam a figura e se fundem com as linhas da margem, abrindo-a. 


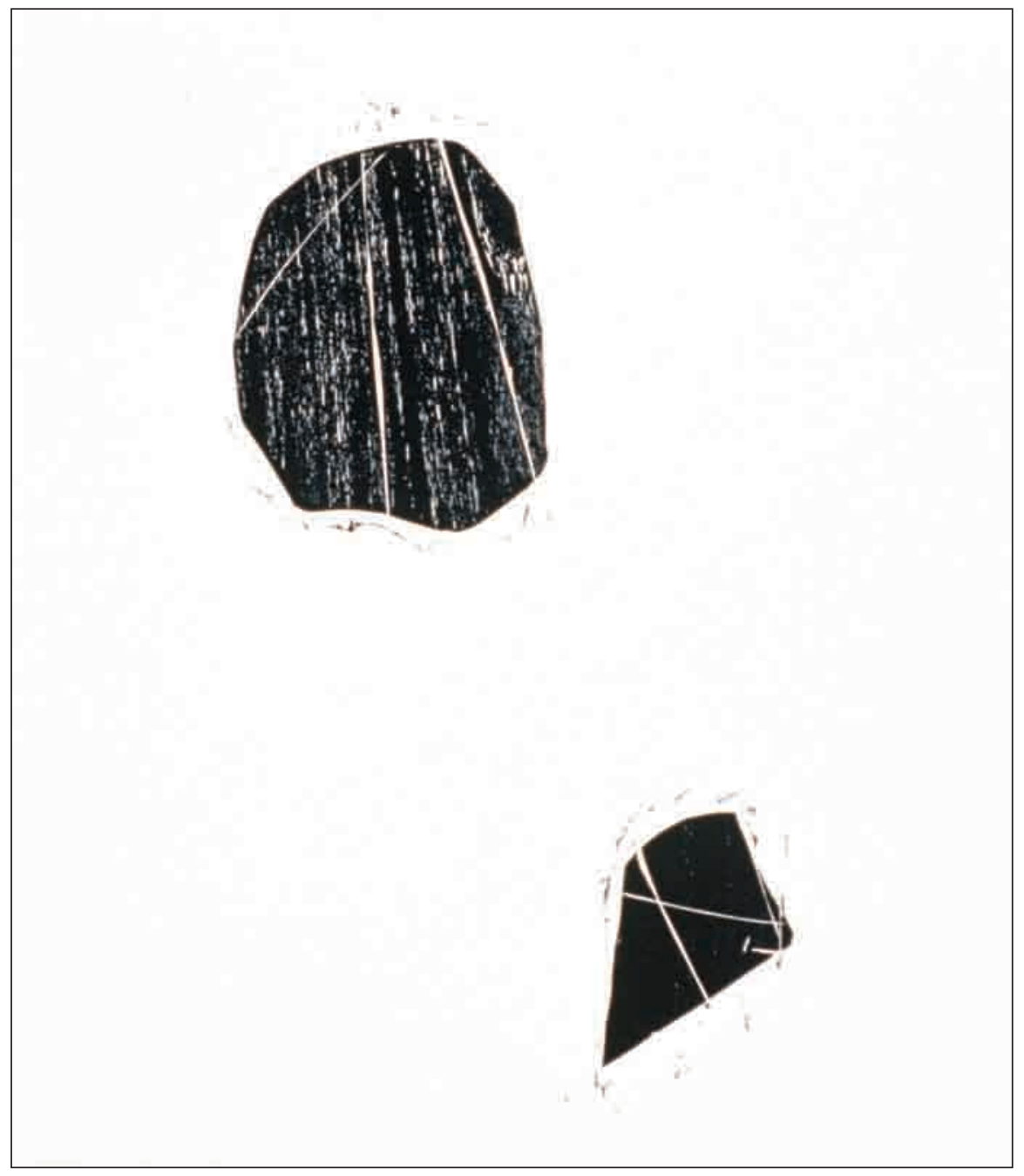

22. Duas Cabeças, 2005 
Um outro trabalho em que a figura se abre de modo bastante evidente é a "Figura 25 Aberta", em que parti da gravação de linhas e logo a seguir do desbaste de uma massa no interior do bloco. A forma se organizou pela relação entre as áreas desbastadas e o bloco de madeira. Procurei aproveitar novamente o limite da tábua como limite da forma. A partir da massa interna desbastada, que se manifesta como massa luminosa na impressão, e de linhas luminosas que apontam partes do corpo, cheguei a uma forma aberta em que a luz atravessou a figura ao eliminar os contornos abaixo e acima da forma, abrindo-a. 
23. Figura Aberta, 2001

24. Justaposição: Figura Hierática, 2005 e Figura Aberta, 2001
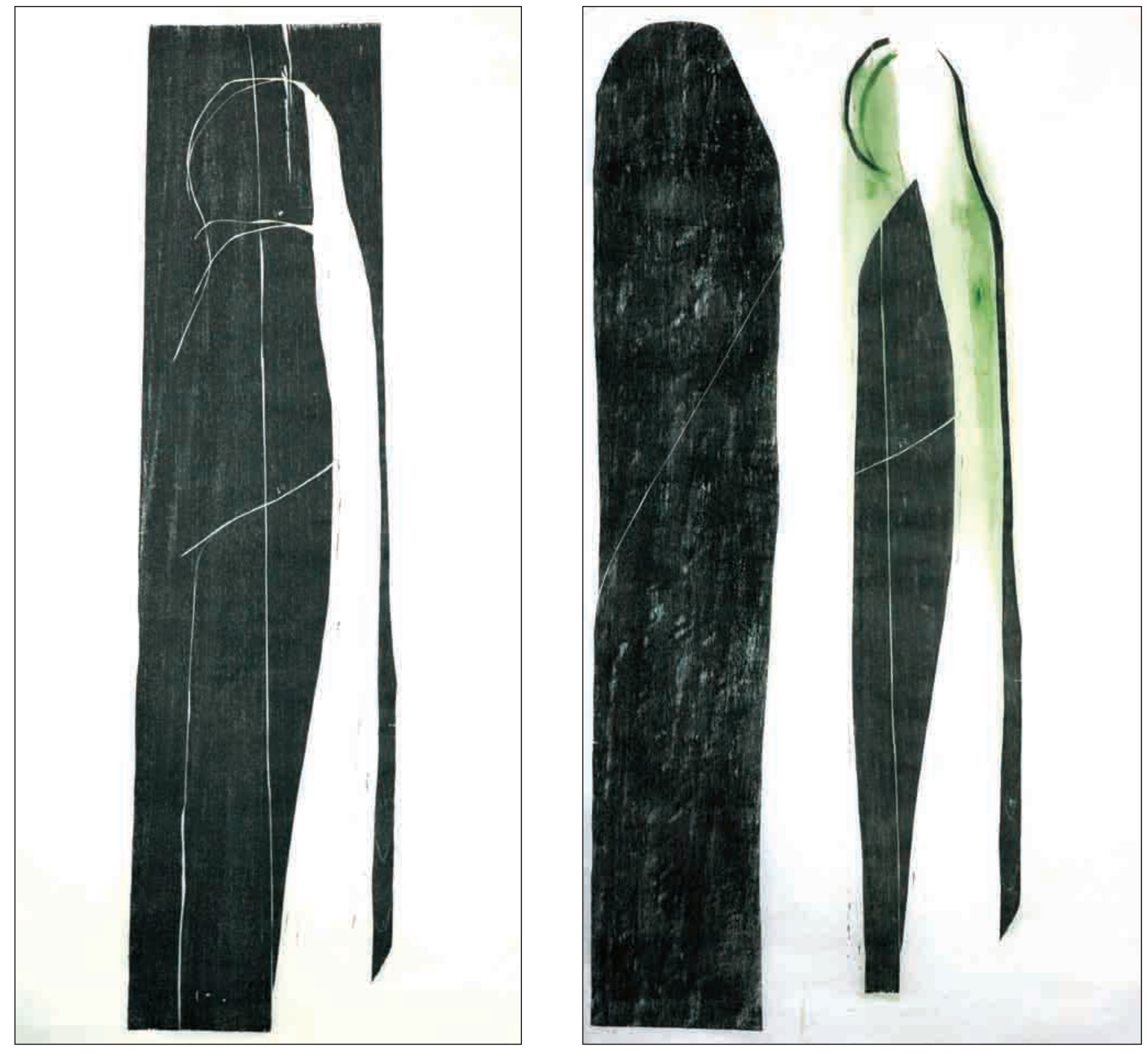
A figura se constituiu no diálogo entre a verticalidade e a sinuosidade da forma, conduzido pelas linhas e pelo diálogo entre elas e a massa luminosa em seu interior, que a integra ao mesmo tempo em que a abre para o seu entorno. 
"Linha Contínua Aberta" se abriu a partir de seu contorno, construído por uma linha 26 em relevo. A princípio esta linha era larga e contornava a figura, havendo uma abertura apenas em sua base. Após as primeiras impressões, decidi tornar a linha mais fina, mais precisa, e a abri, interrompendo o contorno ao alto da figura também. Pelo olhar e através das tensões entre as linhas é possível reconstituir o delineamento e a unidade da figura. Nesta gravura há um confronto entre a linha que manifesta um gesto direto e seu processo construtivo, de encavos e desbastes sucessivos. A linha propõe um gesto contínuo, mas na verdade é resultante de muitos, o que pode roubar sua força, tornando-a contraditória entre o gesto que se anuncia na estampa e sua construção na matriz. Esta gravura revela um enfrentamento para reunir o delineamento e sua construção. 


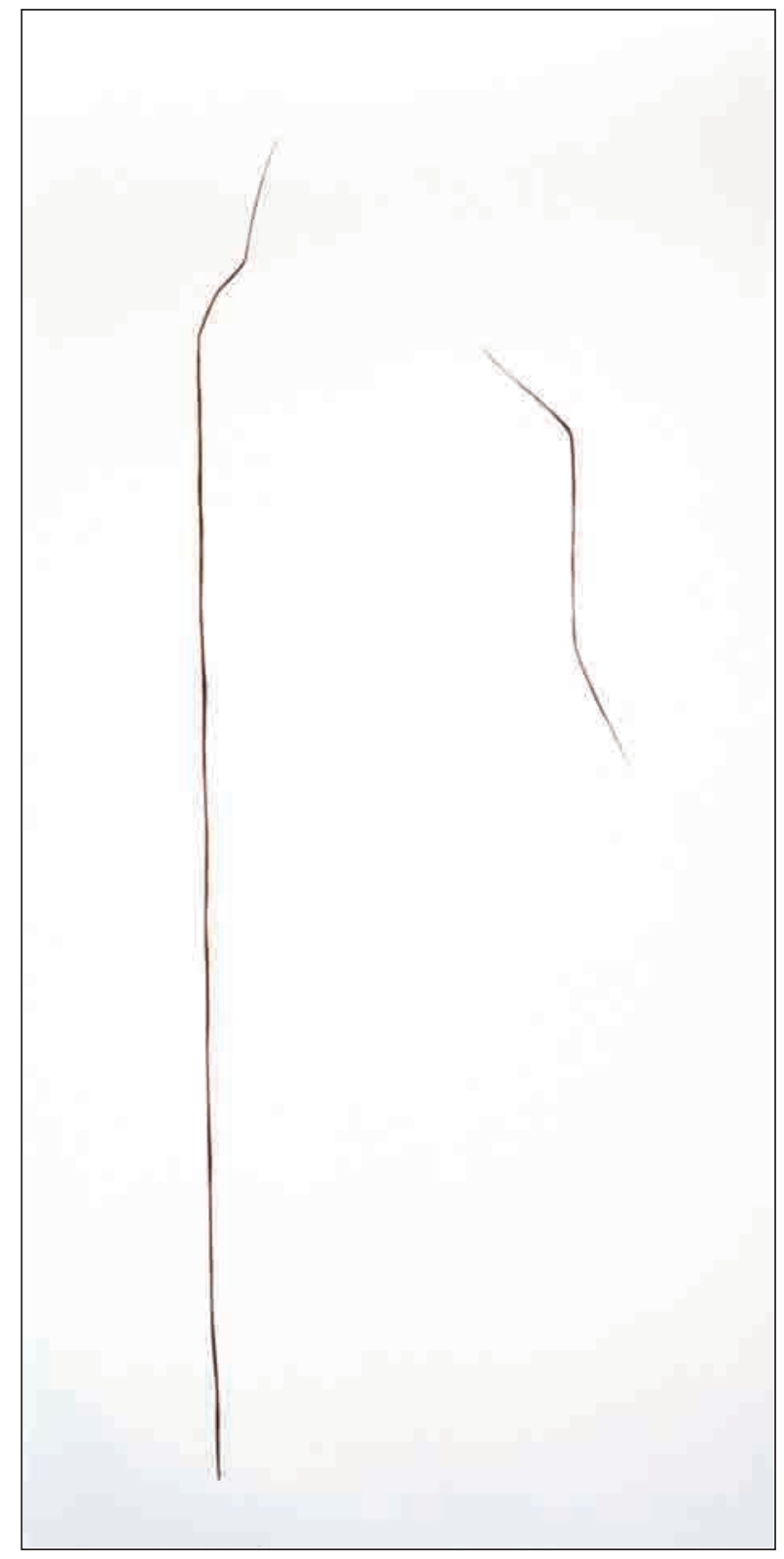


De seu momento inicial à atual configuração, a gravura "Núcleo Corda" foi sempre 27 conduzida por uma tensão gráfica estabelecida a partir de uma linha gravada que atravessa a matriz de alto a baixo. 


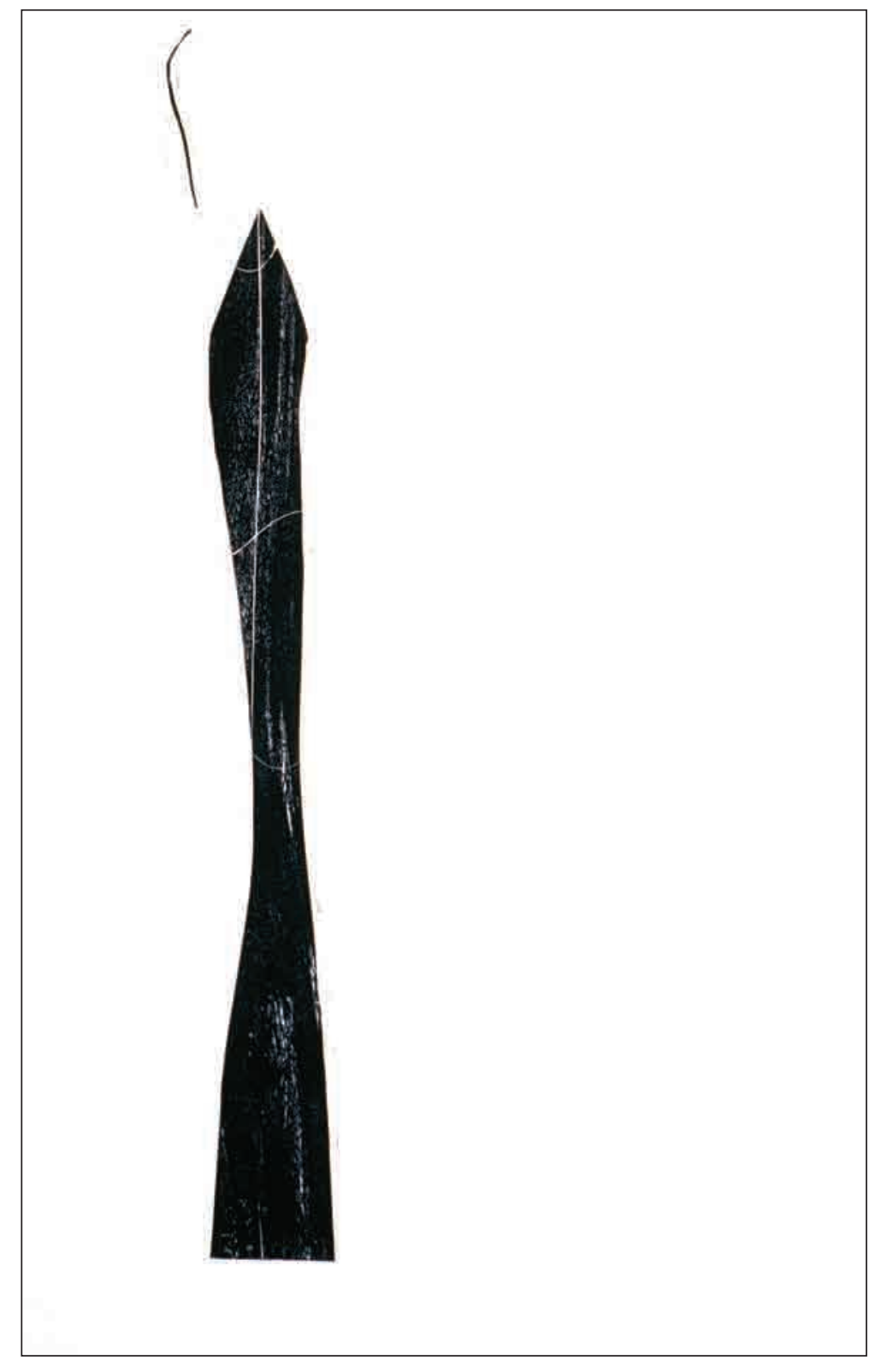


A princípio, na primeira gravação feita em 2001, busquei construir a figura por uma linha que atravessasse toda a prancha, uma linha que tivesse um desenho e uma força tal que constituísse uma forma. Decidi depois gravar nova linha que fosse de encontro ao limite da madeira e desbastei o seu entorno, chegando a uma configuração na qual o prumo reverbera nas duas linhas, e a linha interna em sua massa é também a sua margem.

Havia um sentimento de que a força da linha inicial havia se diluído. Decidi transformar a gravura neste ano de 2006, me orientando pela linha de força inicial, com o intuito de recuperar a tensão ali presente, em uma nova configuração. Ao observar esta linha, pensei em uma corda tensionada e procurei relacionar as novas incisões a esta corda. Foi necessário também refletir sobre as novas relações que propunha entre a figura humana e a sua forma, que desejava construir do interior para as margens. 

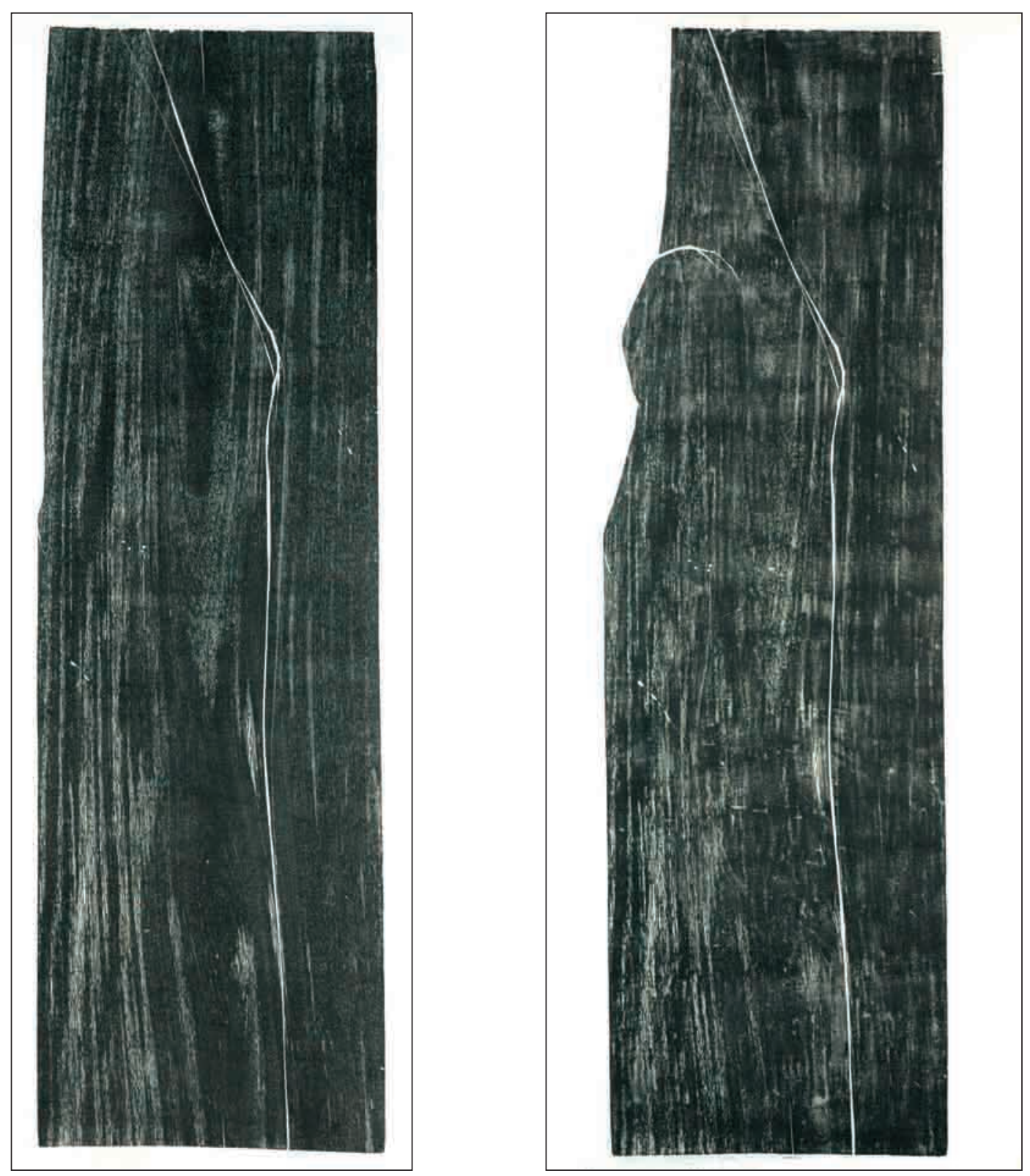

29. Núcleo Corda, 2001 
Ao mesmo tempo em que gravava, fiz uma série de desenhos a lápis sobre papel em folhas aproximadamente de meu tamanho, estendidas verticalmente na parede. Tomei como referência a observação de órgãos e sistemas do corpo humano, em uma visita a um museu de anatomia, em livros de anatomia, em radiografias de meu corpo inteiro, e no meu próprio corpo. Destas observações, procurei deter uma percepção de organização destas estruturas anatômicas, e trabalhei "de memória", ou seja, sobre aquilo que se fez necessário apreender para o desenho.

Outra prática presente foi da monotipia, desenhando no verso do papel apoiado na matriz entintada, justapondo à impressão de um estado da gravura a impressão da monotipia, em que ao desenhar, traçava também um possível desdobramento daquela forma gravada na matriz.

O desenho se manifestou como pensamento e construção da forma, nos desenhos a lápis sobre papel e nos vários estados da gravura, e no movimento entre estas construções. Ao transformar a gravura, me orientava pela reflexão sobre seus diversos estados, na matriz e nas impressões, e pelo cotejamento com os desenhos. Do mesmo modo, os desenhos se seguiram, em um processo de reflexão em que cada novo trabalho se orientava pelos desenhos anteriores e pelos estados da gravura. Neste processo, esteve presente também um movimento de projeção, ou seja, o desenho, como processo de construção e entendimento da figura, se orientava pela reflexão sobre as experiências anteriores tensionadas pelo desejo, pelo sentimento do que poderia vir a ser, do que poderia se manifestar nos próximos trabalhos. 

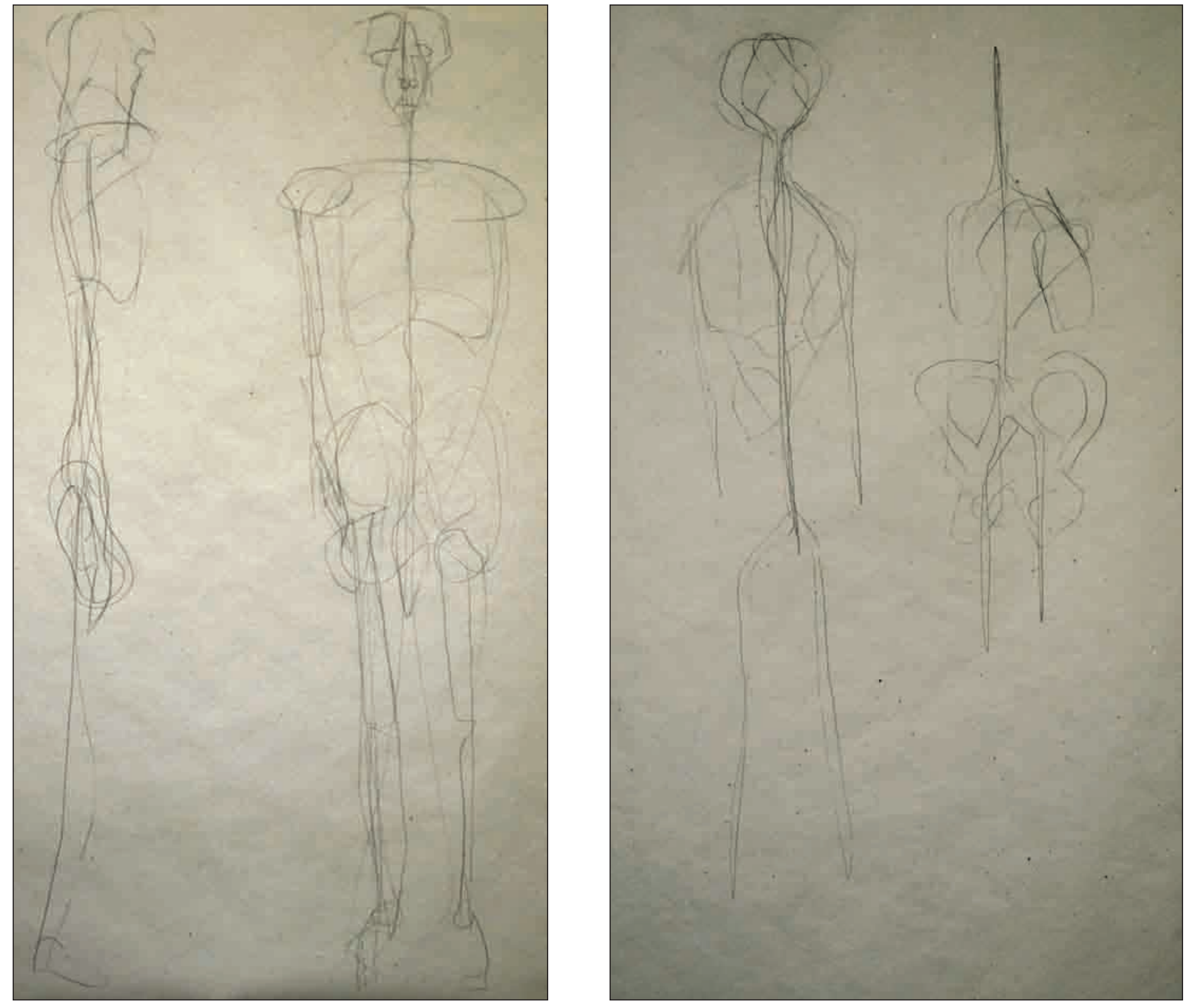
A figura situou-se em um território do devir, em que a sua presença, sua evidência concreta advém de manifestações anteriores e projeta outras. Este devir é possível pela concretude e pela presença de cada manifestação.

$\mathrm{Na}$ sua atual configuração, busquei pelas novas incisões encontrar uma forma que tivesse a linha-corda no seu centro. As linhas gravadas sugeriam várias formas possíveis, e me encontrei em uma situação em que tinha que decidir o caminho a seguir, como se estivesse diante de um mapa. Observando posteriormente uma folha com impressões justapostas, anotei sobre ela as frases: "toda escolha implica em uma renúncia" e "escolho o silêncio". Resta a pergunta: a que renuncio?

Elegi entre as novas incisões aquelas que constituíssem uma forma nuclear, que estabelecessem uma estrita e necessária relação entre este núcleo e a corda. Renunciei a tudo que não se apresentava como necessário para a integridade da forma. Por fim, a linha-corda permaneceu na margem posterior da figura, e sustenta sua verticalidade e a tensão entre a massa escura que corresponde ao corpo e a linha acima que indica a cabeça, no momento em que a figura se abre. 

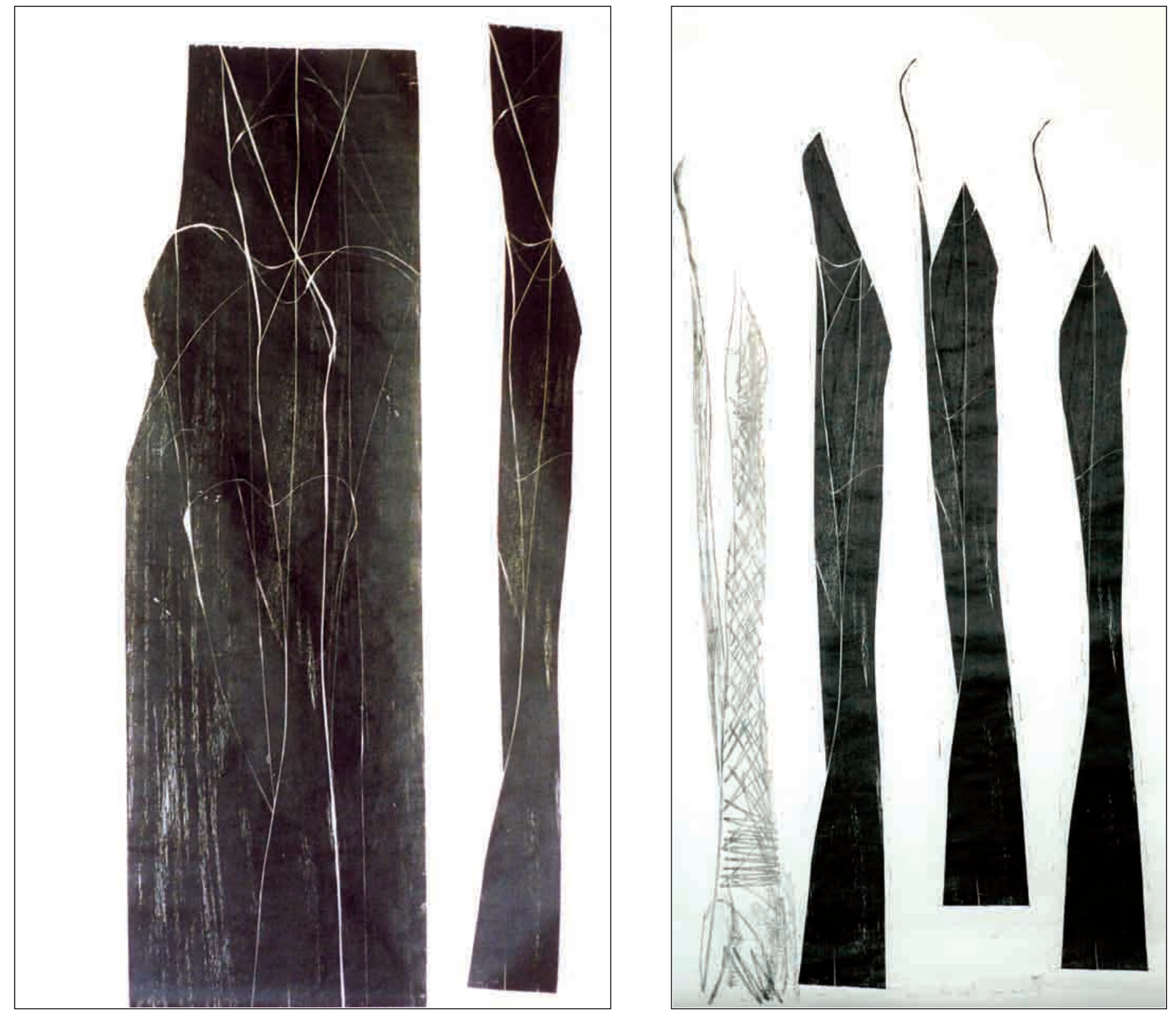

33. Núcleo Corda, 2006 
As gravuras "Figura de Perfil" e "Figura Hierática" foram gravadas em dois lados de uma mesma tábua, e acabaram por tomar caminhos distintos, mas que se cruzam em muitos aspectos. Em ambas parti da mesma proposta, de imprimir a tábua, que é bastante irregular, tanto em seu recorte como em sua textura, e de gravar uma figura considerando a forma da tábua como nuclear em sua forma. Propus-me a trabalhar com poucas incisões suficientes para fazer a figura emergir da tábua. 
Na primeira gravação da "Figura de Perfil", considerando a extremidade da tábua como linha de contorno e as proporções de um corpo, tentei encontrar um ponto em que uma incisão determinasse o lugar e a forma de uma cabeça que se diferenciasse do restante do bloco. Errei na proporcionalidade, a cabeça ficou demasiado grande, e errei na incisão, abri demais os encavos e as luzes na região do pescoço cindiram a figura em dois, destacando a cabeça do corpo. Decidi então operar uma dupla transformação, e inverti o sentido da figura, suas costas se tornaram sua face, e ao invés de uma superfície com incisões, trabalhei com linhas em relevo, desbastando o seu entorno. Para chegar à configuração atual, investiguei algumas possibilidades de delineamento, para decidir quais linhas deveria deixar ou eliminar, utilizando o recurso de imprimir provas justapostas a outras estampas e procurei afinar as linhas, para torná-las mais agudas e precisas. Procurei também um equilíbrio entre a linha negra e o vazio em seu entorno, pelo afinamento da linha por meio de desbastes e por seu posicionamento no papel. 

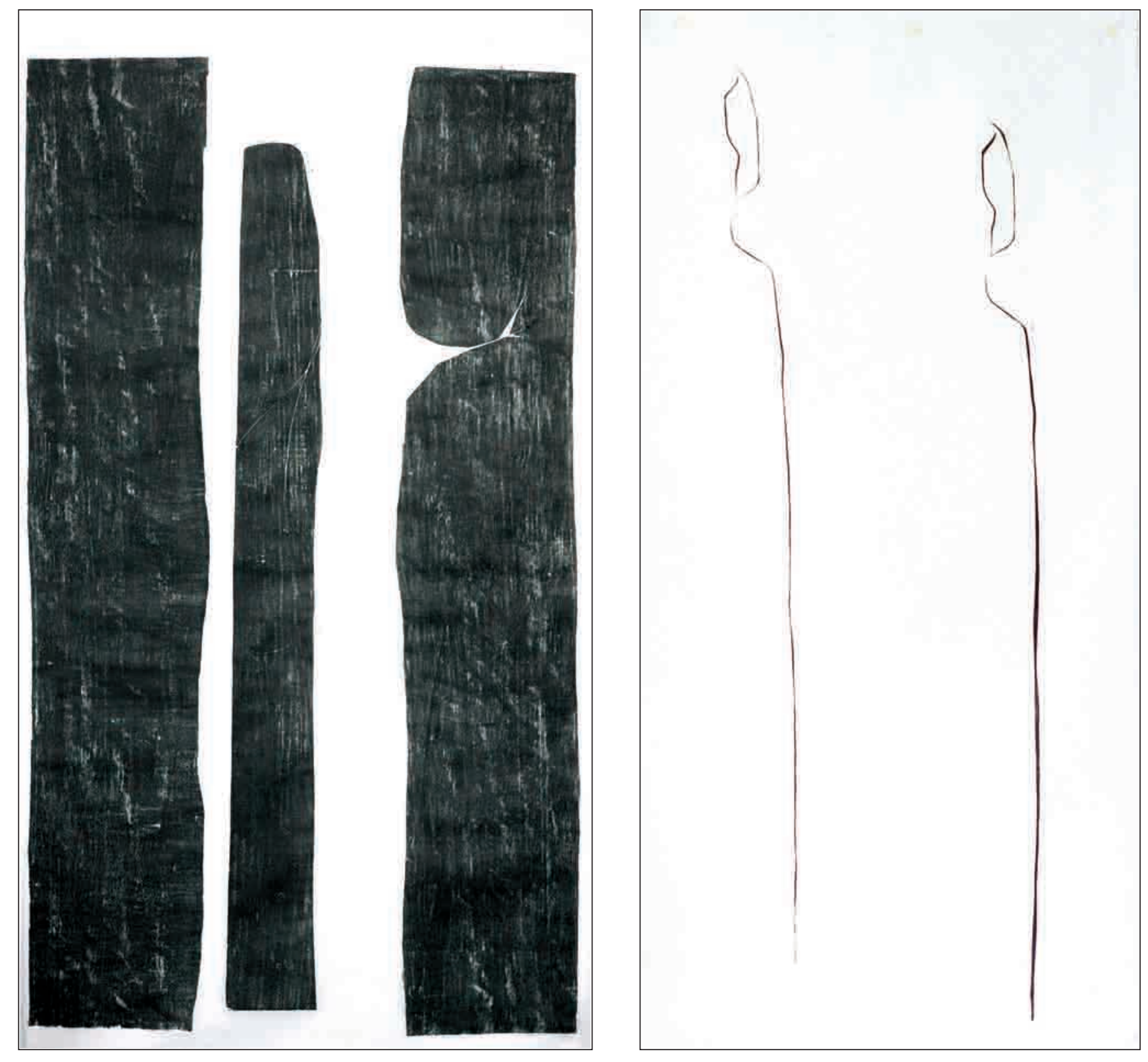

36. Figura de Perfil, 2004 
$\mathrm{Na}$ "Figura Hierática" voltei a enfrentar a proposta de partir da forma da tábua para a forma da figura. Desta vez, gravei uma linha diagonal atravessando a tábua que corresponde a uma linha que vai da base da cabeça ao quadril. Considerando esta linha gravei o contorno da figura, que se desprendeu do formato da tábua, conservando porém um tensionamento. A principal necessidade nesta definição do contorno foi da estabilização da forma, entre sua verticalidade e a diagonal que a atravessa. Procurei estabelecer uma continuidade entre as linhas externas e a diagonal. Aproveitei uma saliência da tábua localizada no ponto em que a diagonal principia ao alto, que enuncia os ombros e acima deles a cabeça, e estabeleci duas verticais que delimitam a figura, encontrando as linhas de prumo em seu contorno. Com a sucessão de novos trabalhos, passei a imprimir sucessivas provas no mesmo papel, por vezes ao lado de provas de outras gravuras. A princípio a própria necessidade de aproveitamento do papel motivou esta atitude, mas percebi a possibilidade que se oferecia de comparar distintos processos e considerar isso nas minhas decisões, de refletir sobre as margens do papel em relação às margens das gravuras como também de observar novas figuras que surgem da justaposição de duas impressões. 
37. Figura Hierática, 2005

38. Sem título, 2005
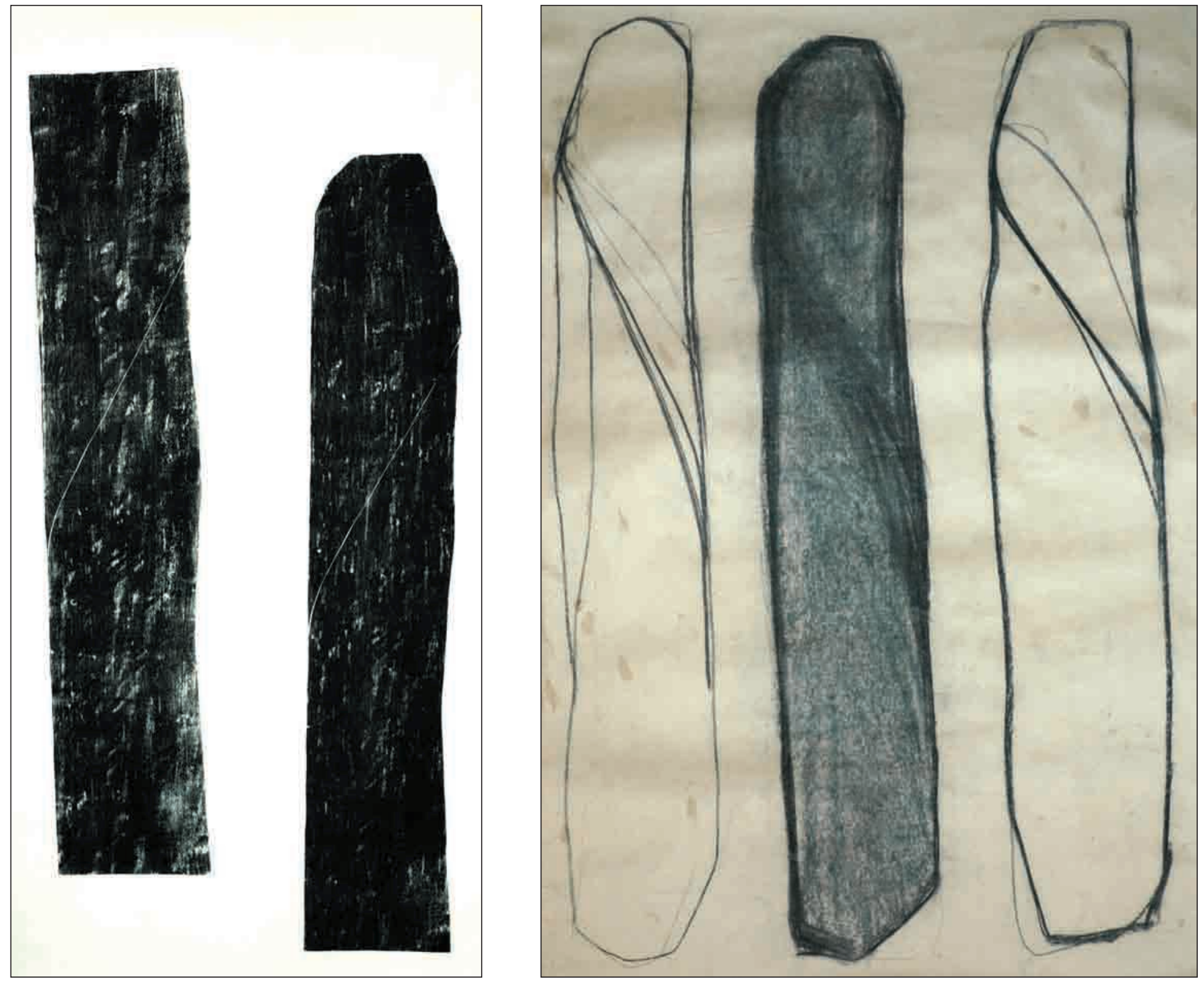
Nesta gravura reduzi de modo contundente os elementos para que se identifique uma figura humana. Isso me traz algumas questões: dificilmente chegaria a esta figuração sem passar pela experiência de trabalho com os conjuntos de desenhos e gravuras, e dificilmente poderia identificá-la como uma figura humana sem observá-la dentro destes conjuntos. A síntese que se manifesta nesta gravura é singular, mas participa de conjuntos em que se constitui a figuração. Neste sentido, aponto alguns aspectos constantes nas soluções figurativas que nesta gravura se apresentam de modo muito sucinto: Um deles é a escala. A relação de escala estabelecida com quem se coloca diante desta forma é decisiva para sua identificação como uma figura humana. Outro aspecto é a proporção, pelo estabelecimento de medidas relacionadas à proporção de uma pessoa. Proponho ainda a verticalidade, no modo como as linhas orientam a figura em relação ao chão e a quem se coloca diante delas. Por fim, a forma, que reúne os aspectos anteriores e deles se constitui, e a clareza da forma, que se encontra com a clareza e economia de meios de sua construção. 


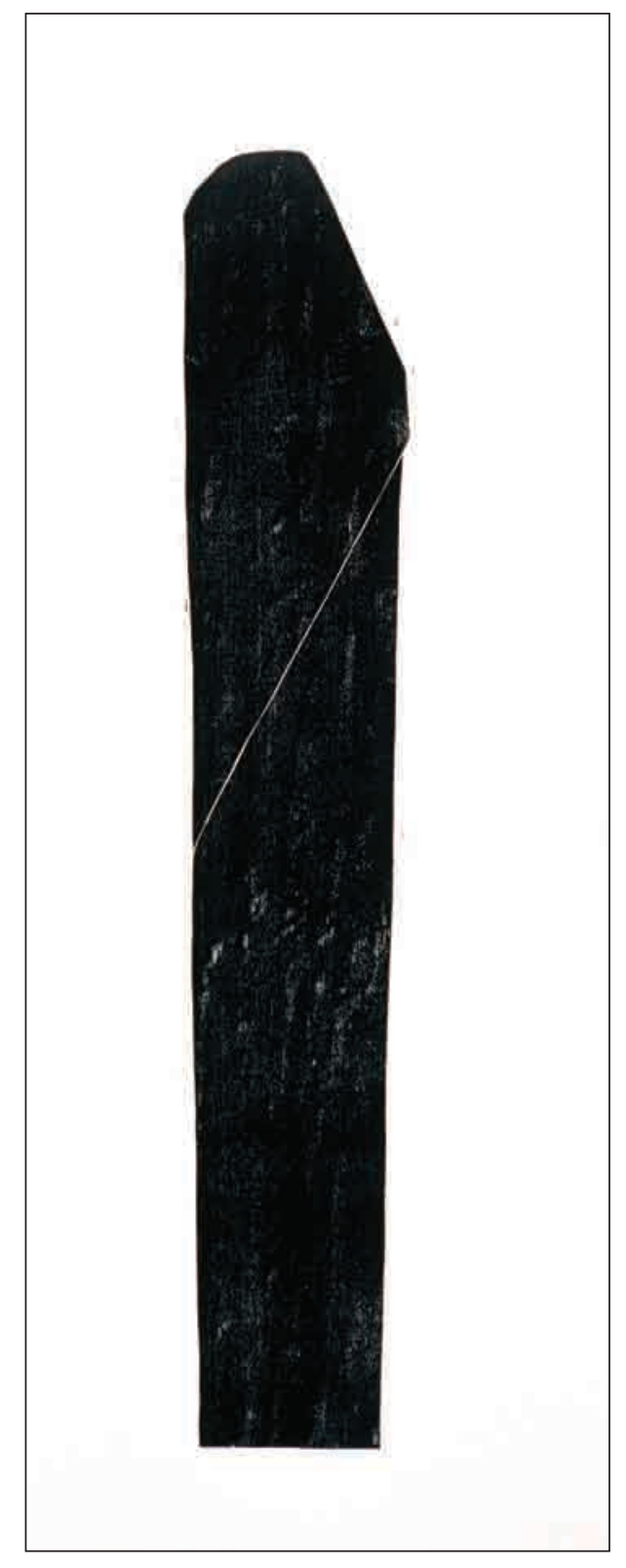


A "Figura Sentada", por mais distinta que seja da anterior, também é muito sintética e pode ser contemplada pela mesma análise. Foi gravada em dois momentos: gravei a

princípio duas linhas em encavo, uma que percorre a figura de sua cabeça, em uma das laterais da matriz, passando pelo joelho, na outra extremidade, até os pés, que ficam na base. A outra linha se cruza com a primeira e vai do joelho ao ombro, e juntas delineiam uma figura sentada de perfil. Ao mover as linhas até as margens da matriz procurei tensionar e trazer para a figura a forma da tábua e nela, a verticalidade. A figura se apóia nas verticais da margem e as traz para seu delineamento. Ao observar na estampa a luminosidade das linhas, senti que era necessário trabalhar melhor a intensidade das linhas para que a figura se projetasse com a intensidade desejada. Decidi também condensar mais a forma, torná-la mais ereta. Ao transformar as linhas, transformaria a forma. 

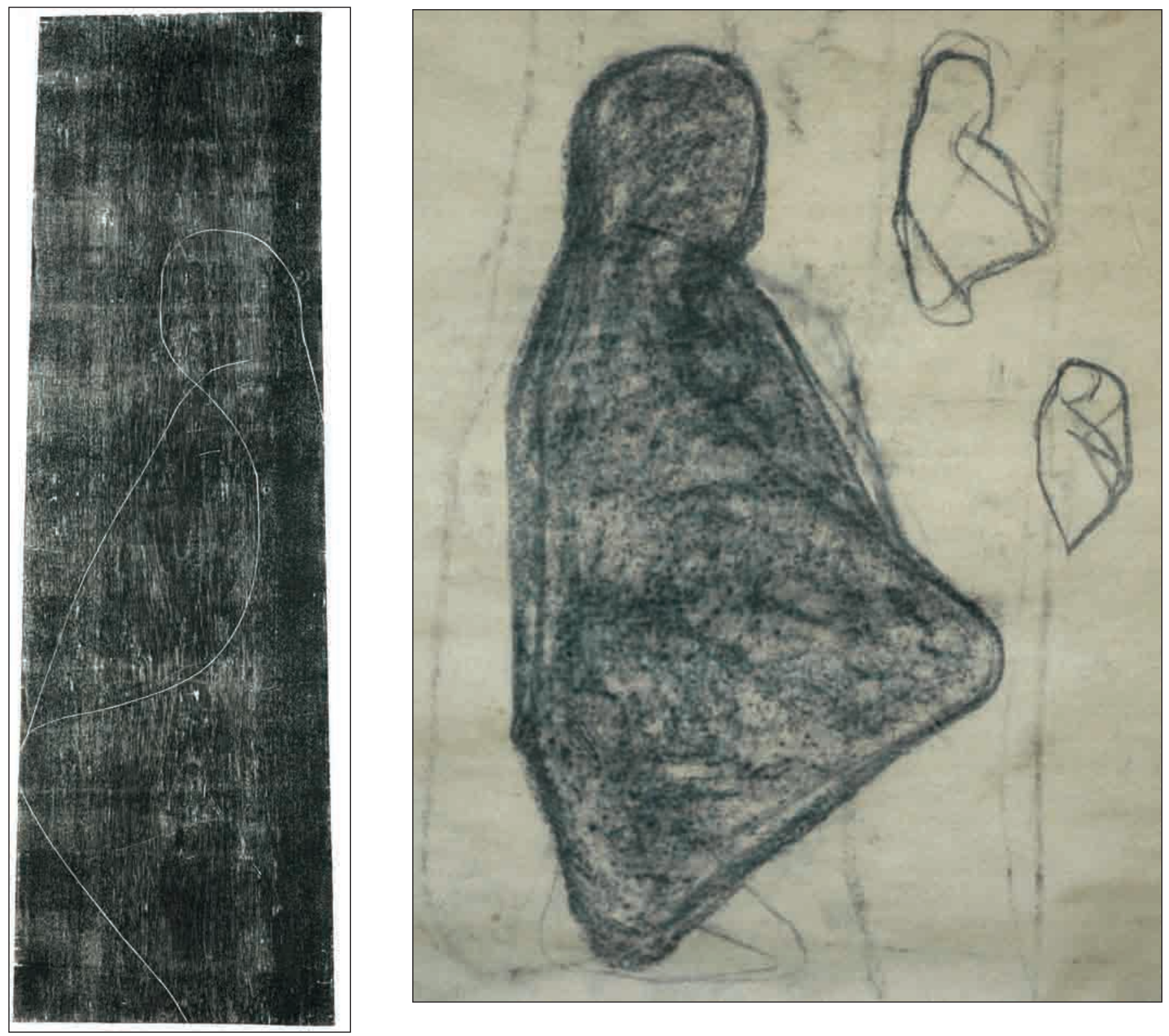

41. Sem título, 2005 
Desenhei sobre a matriz escura com giz claro outras possibilidades de linhas, até encontrar as linhas que dialogassem melhor com as já gravadas. Depois de desenhar, limpei a tinta da matriz no entorno da figura, e a deixei por um tempo assim enquanto refletia se deveria gravar as linhas em encavo ou desbastar o seu entorno. Decidi gravá-las em encavo, mais largas que as anteriores, a fim de tornar a figura mais luminosa e densa. Gravei-as no interior das anteriores, entrelaçando-as, percorrendo por um lado o braço e a face e pelo outro o dorso da cabeça e o pescoço. A figura se constituiu no diálogo entre as linhas, e o seu contorno me parece móvel, ou não se define em uma linha, mas na relação entre as linhas, que a estruturam. 


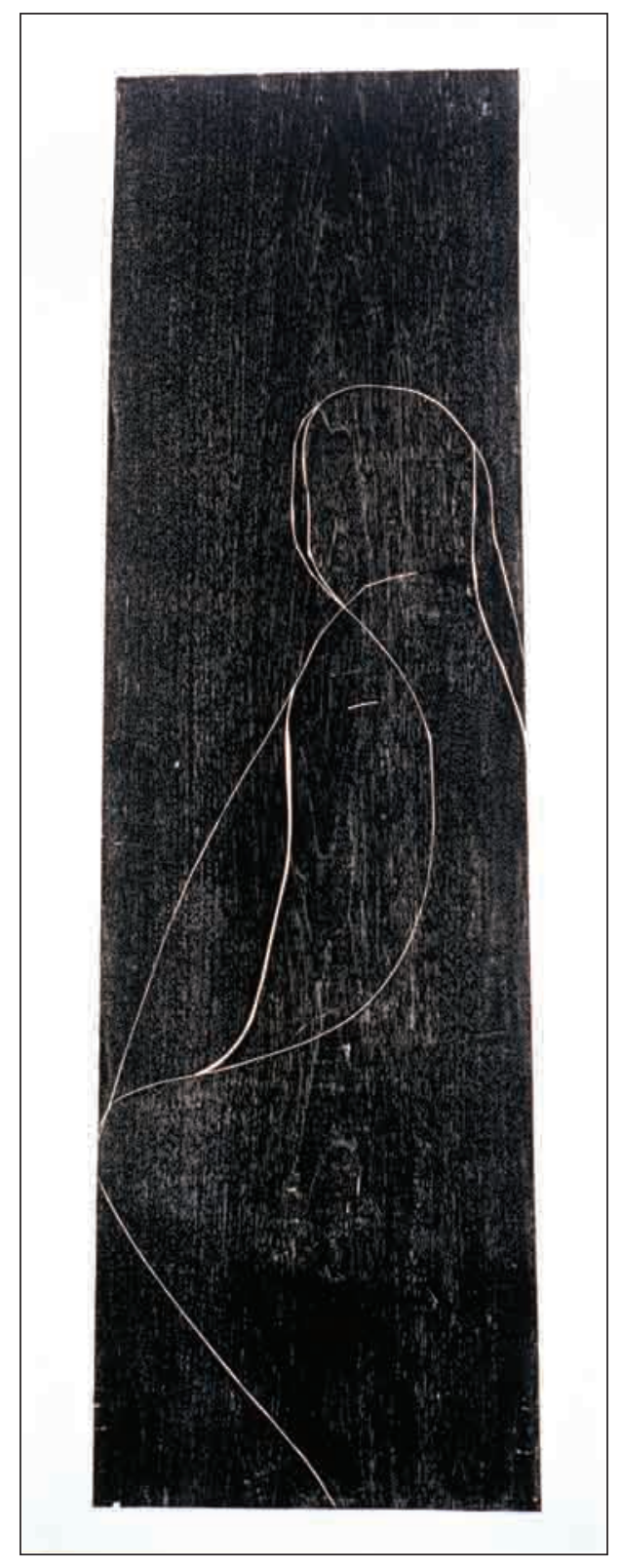


"Duas Figuras": este trabalho partiu da tentativa de gravar duas figuras sentadas e invertidas em um bloco, uma de ponta cabeça em relação à outra. Não deu certo.

Mantive a figura cuja forma estava mais sólida, e que se assentava sobre uma pirâmide

e desbastei a outra em seu entorno, deixando algumas linhas que indicam a presença de uma figura atrás. 

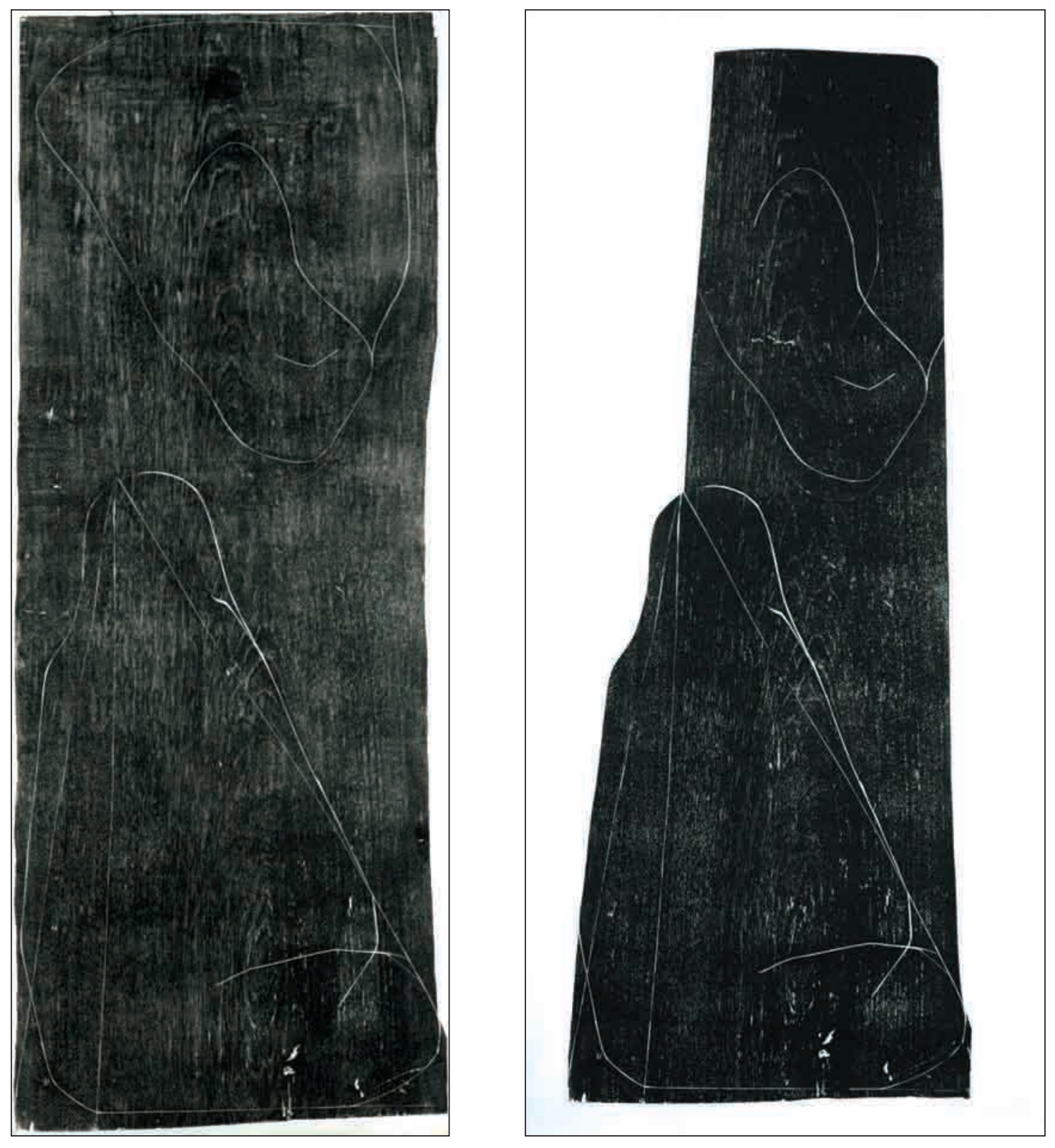

44. Duas Figuras, 2002 
Decidi retomar este trabalho, pois sentia que a figura detrás não estava claramente concluída, as linhas não tinham a coesão ou a força para constituir uma forma, e a figura não se apresentava de fato. Nesta regravação procurei fazer com que a figura detrás se apresentasse concretamente e dialogasse com a figura sentada, havendo uma coesão tal que as duas figuras constituíssem uma única. Parti das linhas que indicavam a figura em pé e as estendi até as margens do bloco gravado, e nesta extensão, redefini as margens do bloco e da figura, que coincidiram. Orientei-me também pela relação entre as linhas que estruturavam a figura em pé com as linhas da figura sentada, no sentido de construir uma única forma que contivesse as duas figuras. Propus um desenho em que pelas tensões entre as linhas e o bloco, definisse uma forma una que se desdobrasse internamente em duas. Para alcançar a concisão almejada, a economia de meios se coloca como uma necessidade intrínseca ao trabalho. O desejo de síntese vai de encontro à necessidade construtiva, para que a figura se apresente enquanto memória e devir. Sua forma concisa propõe uma relação de identidade com a figura humana em que guardo apenas o necessário para que esta se manifeste e permaneça aberta.

Neste processo, o desenho é pensamento e construção, em uma busca da forma em que se encontram o desejado e o necessário.

A figura se apresenta em cada manifestação, e em seu devir, aberta para as experiências passadas e futuras, em constante movimento. 


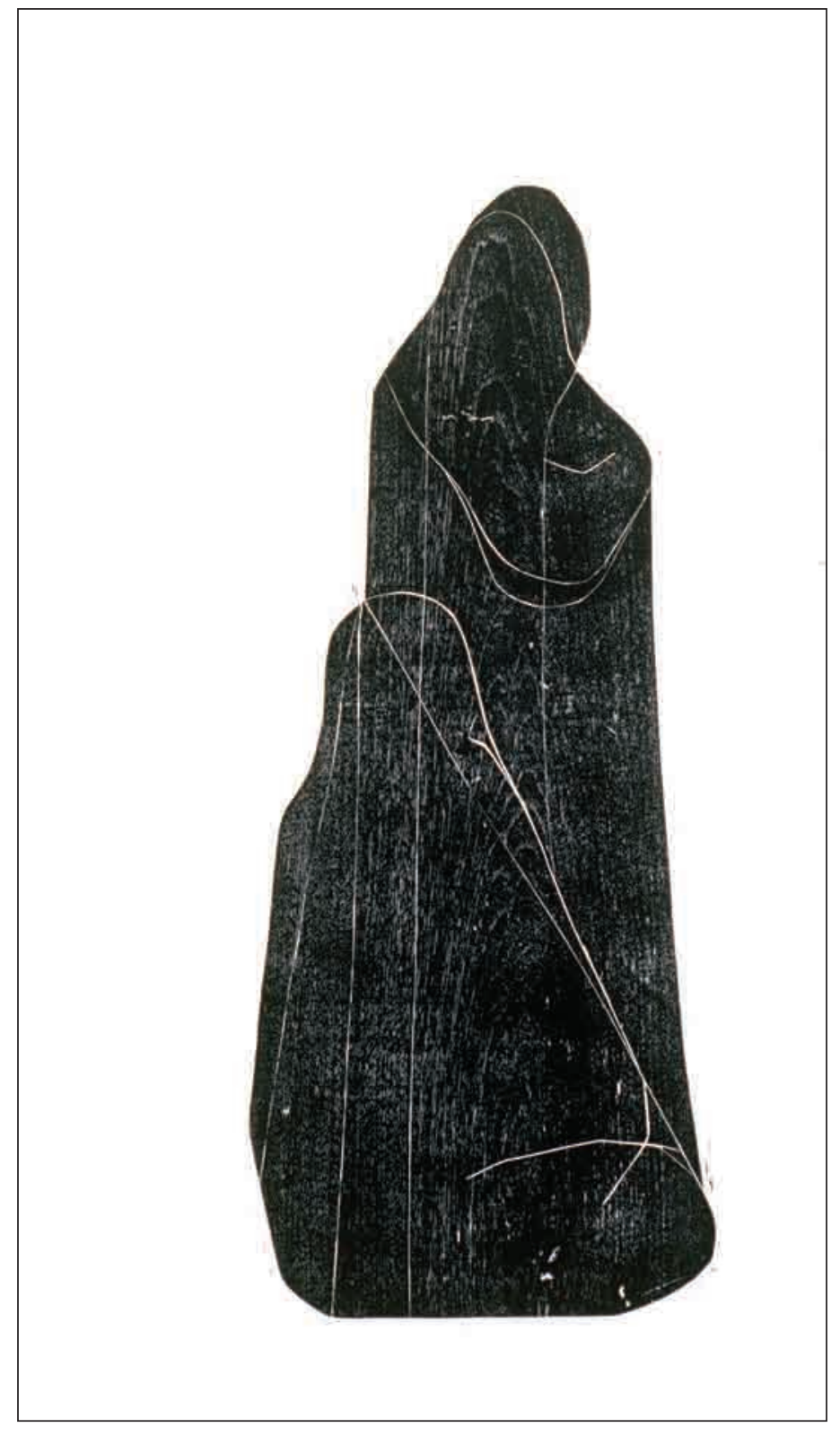


Retratos 
Este conjunto de retratos foi produzido em gravuras em metal, xilogravuras, monotipias e desenhos a lápis, pincel ou ponta de prata sobre papel, simultaneamente à série das figuras, com que partilha questões como a economia de meios e o desenho como lugar fundamental do pensamento e da construção. 
Fiz uma série de desenhos a lápis ou ponta de prata sobre papel em que retratei três pessoas: Manoel, Maria Helena e Adalgisa, a saber, meu pai, minha mãe e minha esposa. Estes desenhos foram feitos de observação, diante dos retratados procurando apreender seus traços singulares. Esta apreensão se deu pela linha, em gestos diretos e concisos. No desenho me movi pelo olhar, pela eleição do que retirar e como traçar as linhas que figuram aquela pessoa. Estes desenhos se fizeram em conjuntos, em sessões em que a pessoa sempre estava presente e ciente de que eu a desenhava, mas nunca "posando" especificamente para o retrato. Não me detive muito tempo em cada desenho, procurei uma transmissão direta, quase imediata entre o olhar e o gesto de traçar, e busquei sempre soluções sintéticas, apenas o necessário para que se configurasse o retrato como o momento de um encontro entre o desenho e a pessoa figurada. 

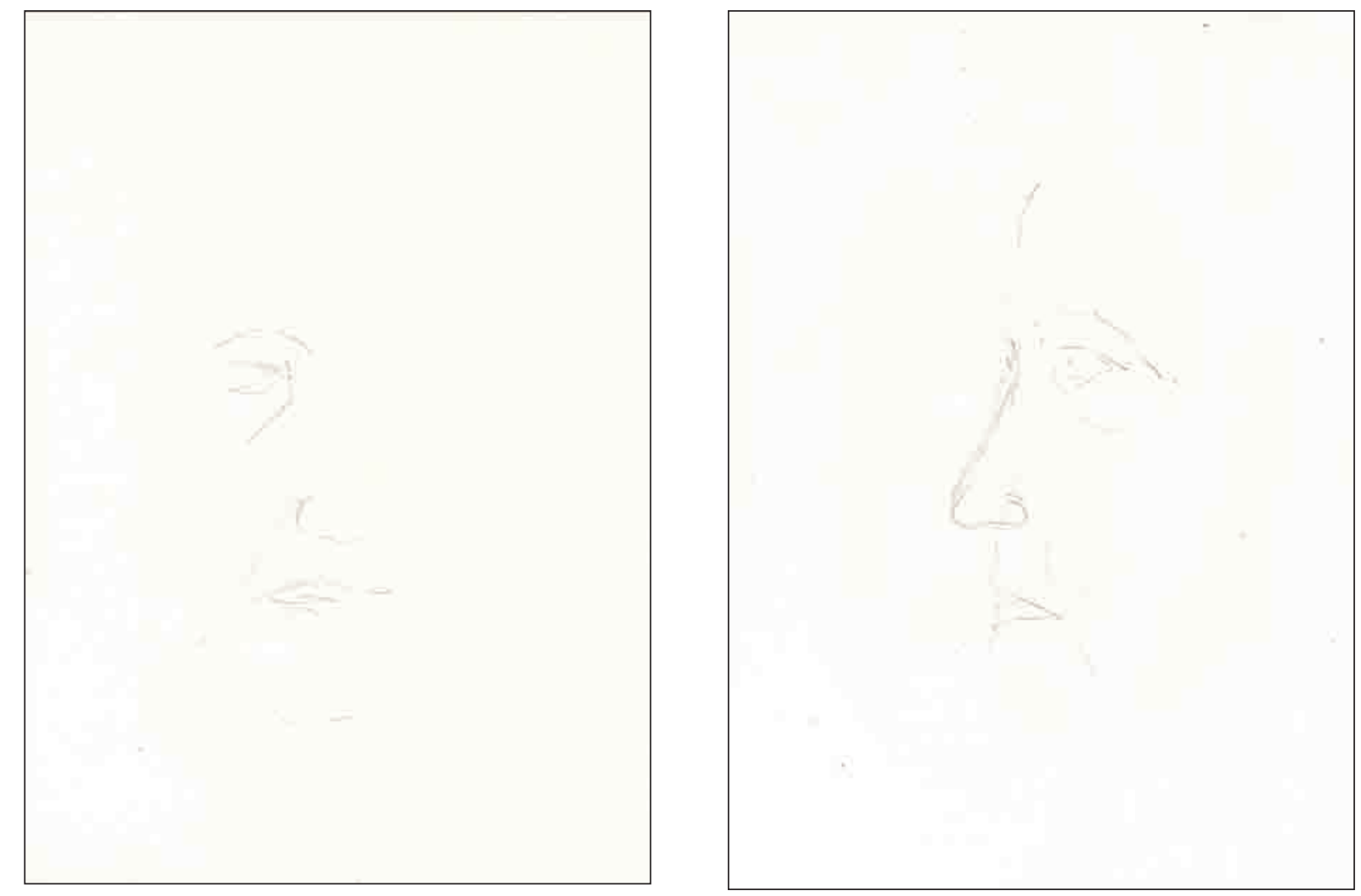

46. Sem título, 2005

47. Sem título, 2005 
A matéria dos desenhos é significativa para o seu caráter. Na maioria, trabalhei com lápis grafite duro, que marca, vinca a folha de papel e produz uma linha cinza. Para fazer uma linha mais escura é necessário forçar o lápis contra o papel, aumentando este vinco. Ao trabalhar sobre um bloco de papel, percebi que as linhas ficavam vincadas também nas folhas seguintes. Procurei incorporar estas linhas aos desenhos, somando-as a novos traços com o grafite, tomando para os desenhos estas linhas constituídas apenas do vinco no papel. Neste momento, materialmente, os desenhos se fundiram, um traço por vezes marcava de duas a quatro folhas e participava de outros desenhos, como vestígio de outro momento, de um encontro que se apresenta novamente. Esta sobreposição e justaposição de desenhos indicam uma temporalidade em que os retratos convivem nas simultaneidades e transformações. 

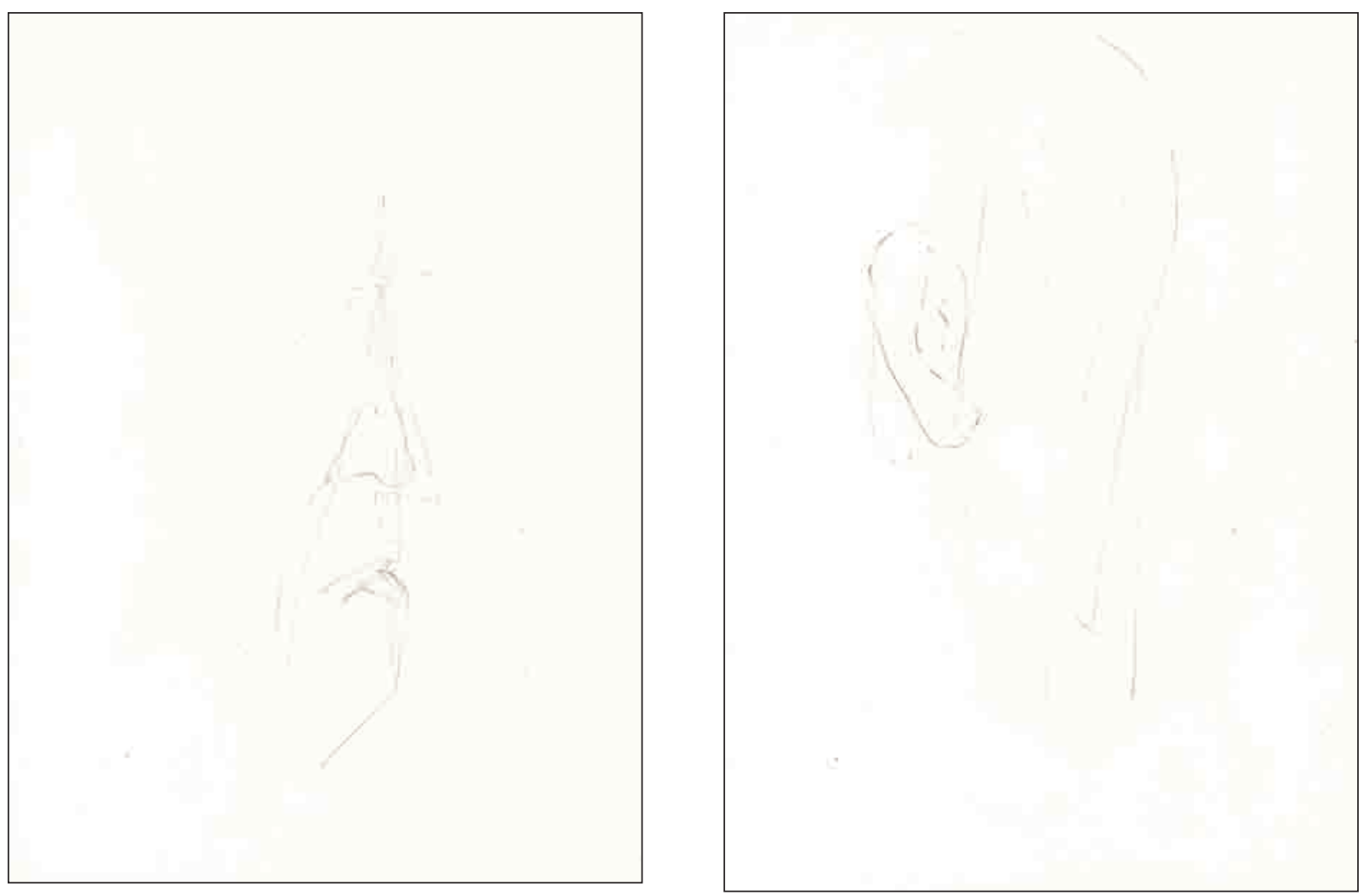

48. Sem título, 2006

49. Sem título, 2006 
Posteriormente, passei a colocar uma folha de papel rígido sob a folha em que desenhava para impedir a transmissão da linha vincada para as folhas seguintes, e desta forma evitar entrar em um território do "já sabido" nestes desenhos, pela repetição de um procedimento. A prática do desenho sempre se assenta sobre um conhecimento, mas é necessário enfrentar cada desenho em sua singularidade, e para isso é importante evitar a repetição não refletida de procedimentos. Neste sentido procurei ainda alternar materiais, como a ponta de prata e a pedra negra. 

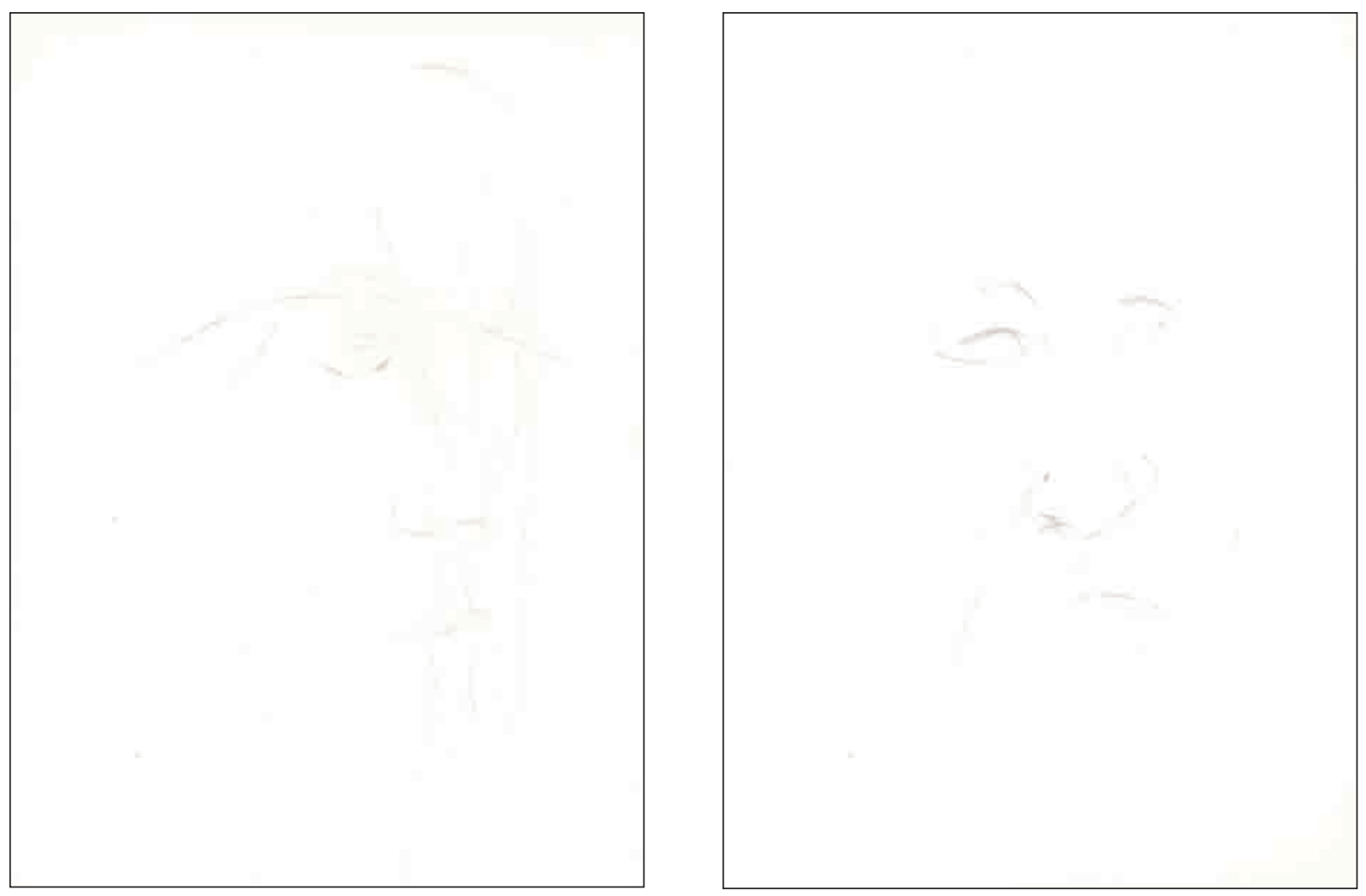

50. Sem título, 2005

51. Sem título, 2005 
$\mathrm{Na}$ busca de captar e tornar presente a figura, de ir ao encontro do retratado, almejo que cada um destes desenhos se afirme individualmente, e em seu conjunto formem um outro desenho. Neste sentido percebo que, mesmo quando a linha vincada de desenhos anteriores não está presente, há um encadeamento entre os distintos momentos, em que os desenhos portam os anteriores, se manifestam plenamente em si mesmos e se abrem para manifestações futuras. Tomados em seu conjunto, postos lado a lado, revelam a singularidade e a cumplicidade de cada manifestação. 

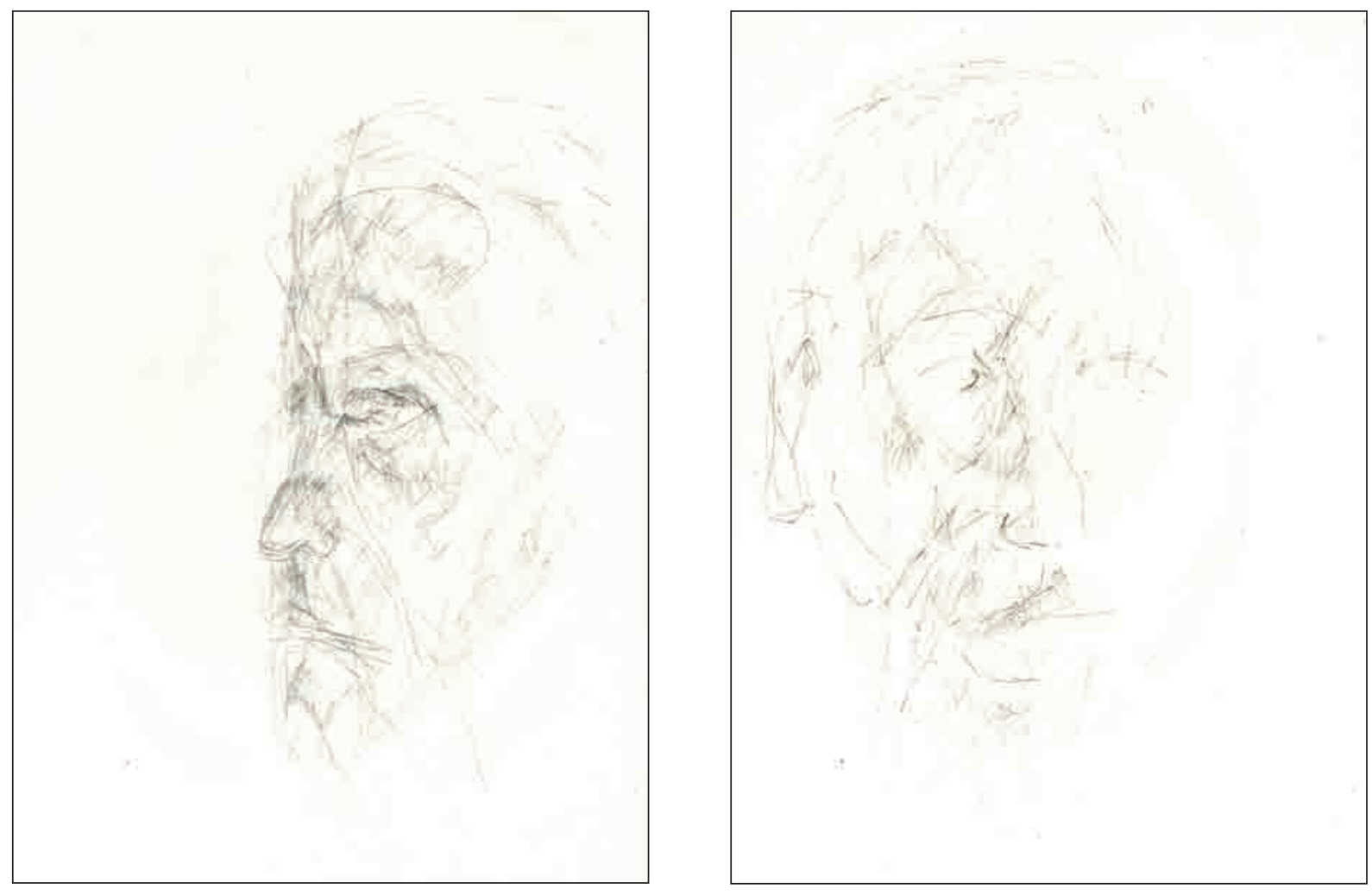

52. Sem título, 2005

53. Sem título, 2005 
Noto uma constância na concisão da linha, na colocação da linha no campo do papel e na decisão do momento de encerrar o gesto no momento preciso, em que a linha e o vazio, o traçado e o não traçado se equilibram. Constituído pelas marcas e pelo vazio, pela eloqüência e pelo silêncio, em que por vezes os vazios são mais eloqüentes que as linhas, ou as tornam ainda mais evidentes, se manifesta o retrato como este desejo de encontro que se faz presente no desenho. A decisão de deter no desenho este instante preciso é simultânea e tão importante quanto a precisão da linha. Seguir adiante poderia significar a diluição da forma, a perda do momento em que a figura se faz presente. Aceitar este movimento de torná-la presente implica em deixar aberto espaço para o silêncio, na forma aberta a figura se completa na memória, e na memória se perde e se abre para outras manifestações. O devir se situa neste território em que presença e ausência se encontram, e a figura se atualiza e se abre para manifestações passadas e futuras. Nesta busca constante da forma aberta, é necessária a construção sintética do desenho, em sua economia de meios. 

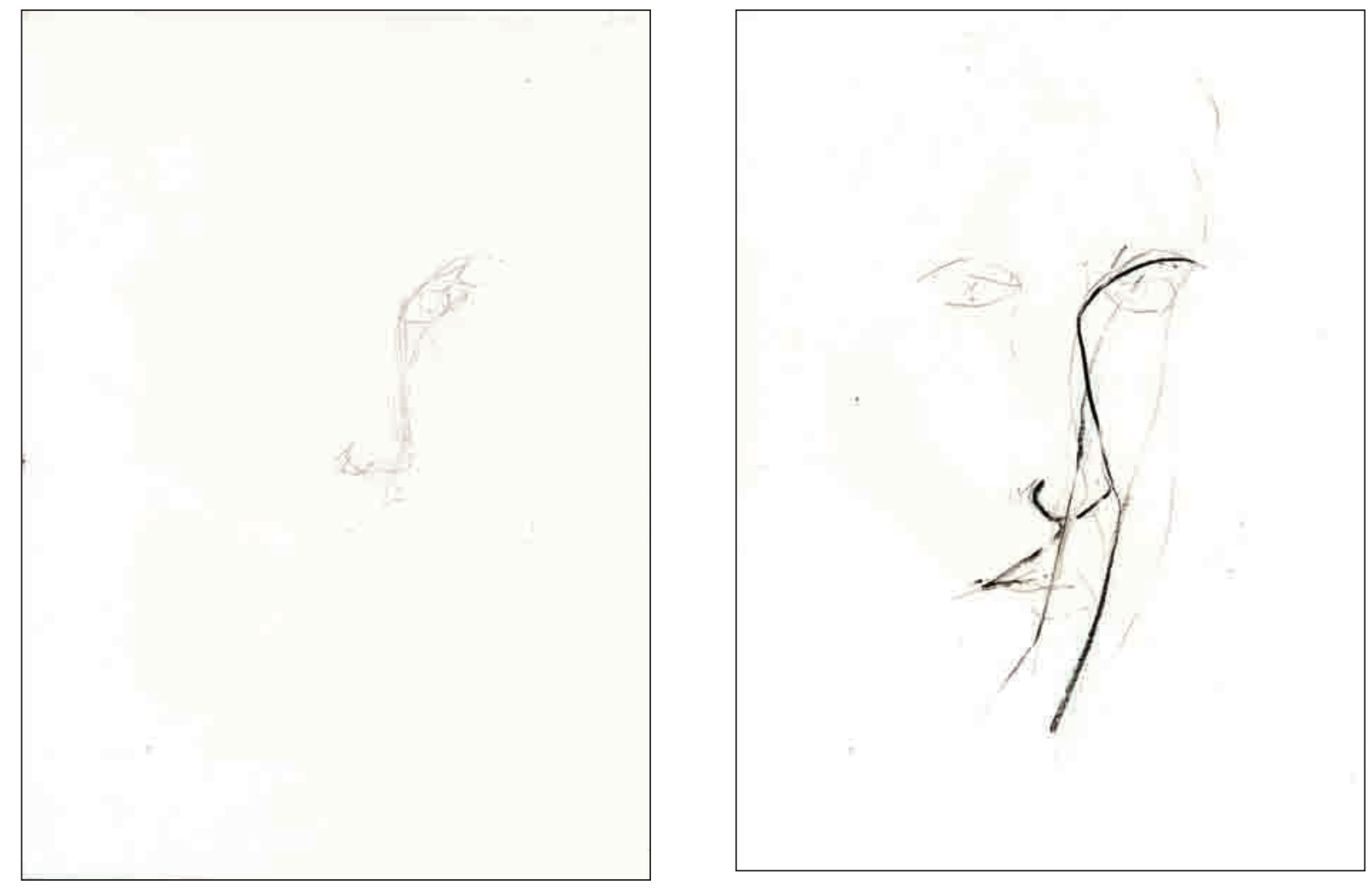

54. Sem título, 2005

55. Sem título, 2006 
Contemporaneamente aos desenhos sobre papel, fiz também uma série de retratos em gravuras em metal. Inicio o depoimento sobre esta série pela análise de três obras:

"Retrato de Adalgisa", "Retrato Lateral de Manoel" e "Retrato Frontal de Manoel". São

três gravuras em metal nas quais trabalhei entre 2001 e 2005, quando passaram por

transformações que procuro relatar. 


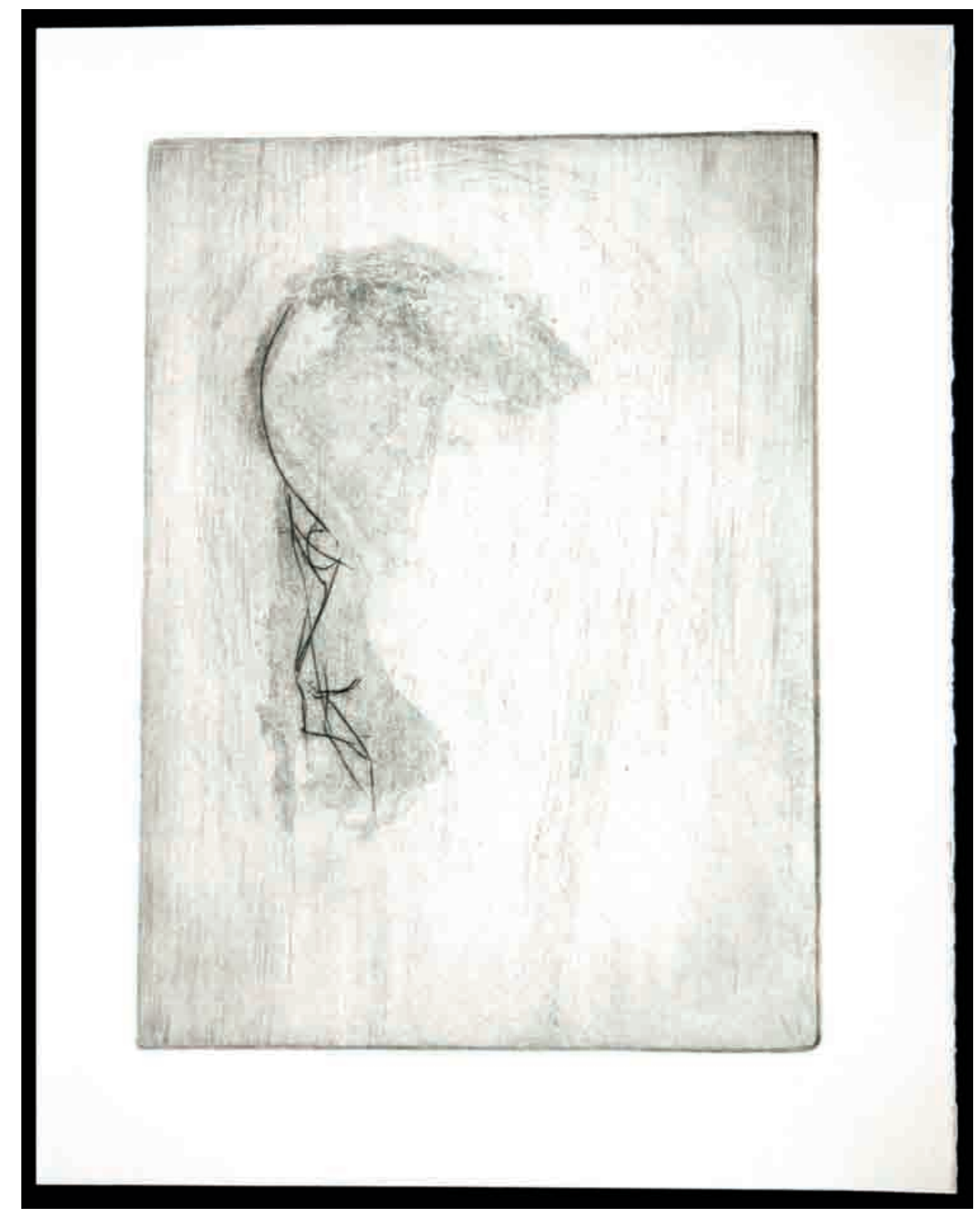




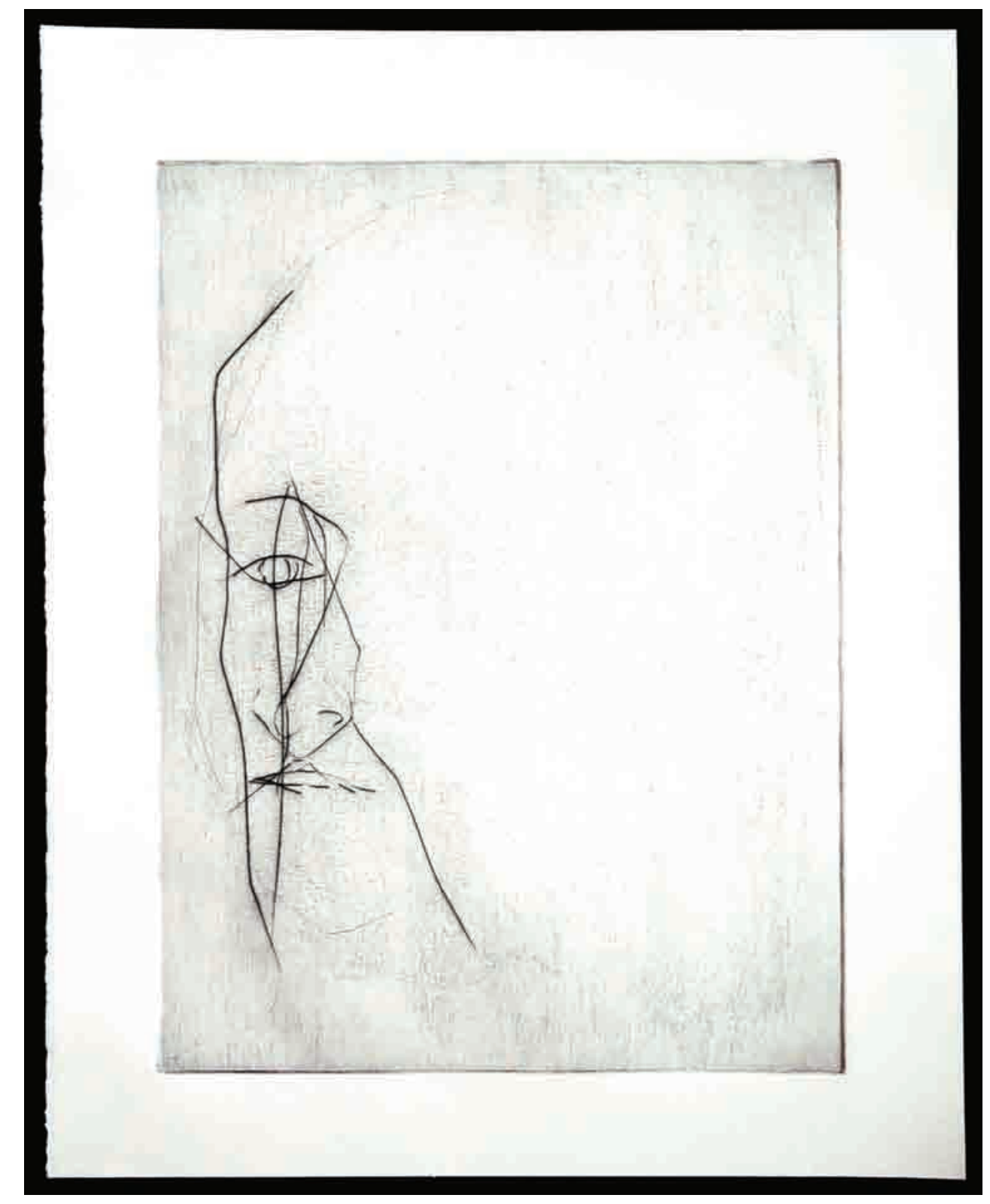




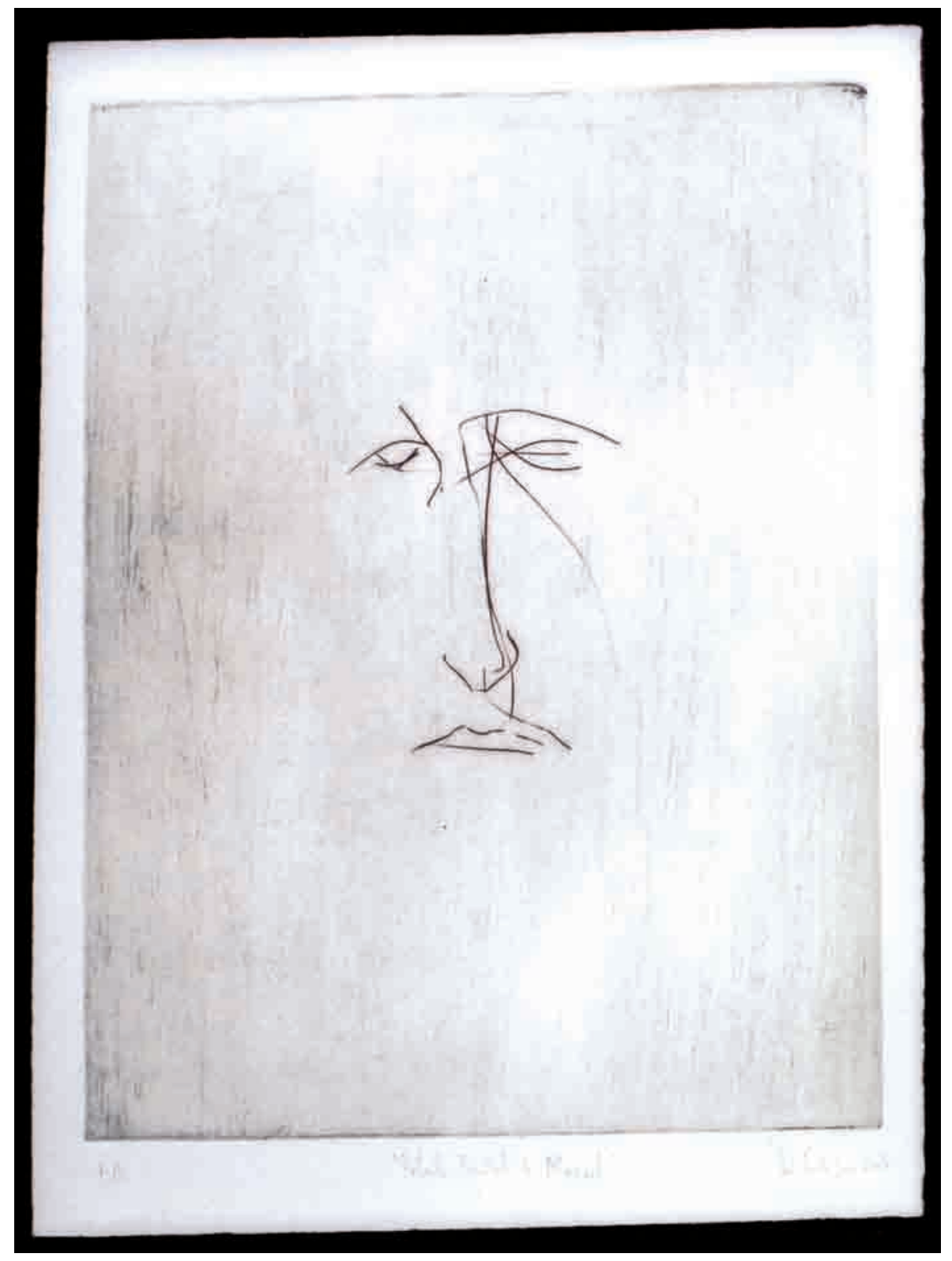


Na sua primeira configuração, tratavam-se de cabeças, e participavam de um conjunto maior, cujo problema central enfrentado foi da construção da forma em contraponto à concisão do corte, na eleição de poucas marcas significativas para a constituição da figura. Buscava a concretude da linha e nesta concretude, a figuração. Para este trabalho optei por um tamanho que estabelecesse uma escala em relação direta com a da cabeça de uma pessoa.

Nas primeiras construções lineares foi constante uma linha de contorno da cabeça, que por vezes penetrou no interior da face, indicando aspectos da fisionomia, ou foi contraposta a outras que marcaram a fisionomia. Algumas destas gravuras permanecem neste primeiro estado até hoje, enquanto outras transformei, seguindo quatro caminhos fundamentais: do acréscimo de linhas, com ponta seca ou água forte, até a constituição de massas; da construção com a mancha, em procedimentos de água tinta e enxofre; do apagamento das gravações, com raspadores, brunidores e abrasivos e da construção de novas configurações lineares sobre as gravações apagadas. Na gravura em metal este processo está diretamente relacionado à natureza dos materiais, às ferramentas e ao modo que são empregados. Desta relação se fez necessário pesquisar distintos processos de gravação e buscar em cada gravura a manifestação concreta que ali se apresenta. 

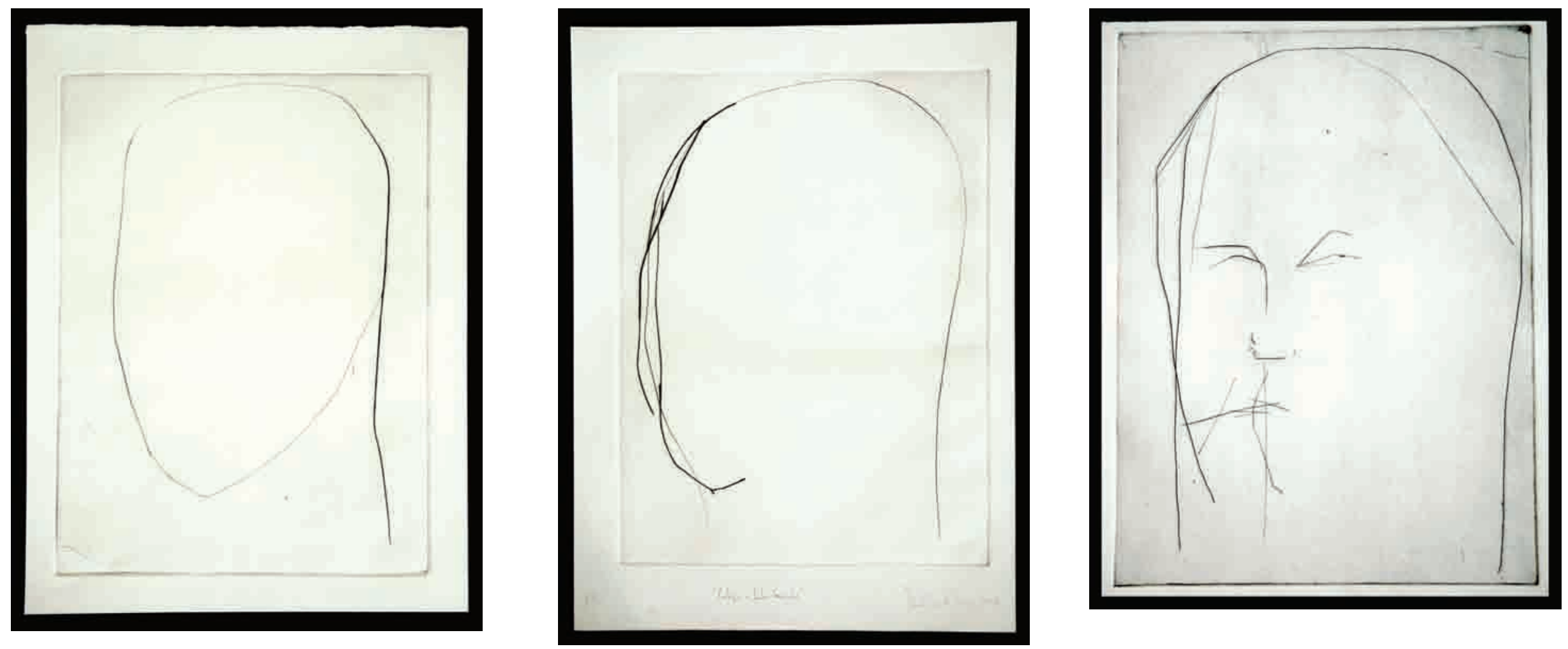
Este processo transcorreu com as matrizes das gravuras "Retrato Frontal de Manoel", "Retrato Lateral de Manoel" e "Retrato de Adalgisa". Nas primeiras transformações, me detive em uma investigação sobre os procedimentos e a forma, ao gravar com água tinta sobre as primeiras construções lineares, raspar as placas, e nas sucessivas provas que fiz notei a possibilidade de lidar com as marcas que resistiam das gravações anteriores. Tanto pela mancha, quanto pelo rebaixamento da gravação e pelas novas incisões, procurei abrir a forma. Ao gravar novamente, já em 2005, a face se tornou o foco de minha atenção, e na face, a construção de um retrato, em que busquei o equilíbrio entre silêncio e eloqüência, em encontrar linhas que designassem aquela pessoa retratada, em suas expressões faciais, em minha memória, no sentimento que nos aproxima.

Nas primeiras transformações efetuadas no "Retrato Frontal de Manoel", gravei manchas que dialogavam com as linhas fisionômicas presentes na matriz. No "Retrato Lateral de Manoel", as manchas foram gravadas em duas etapas, em diálogo com a linha de contorno da cabeça, procurando constituir uma massa. 

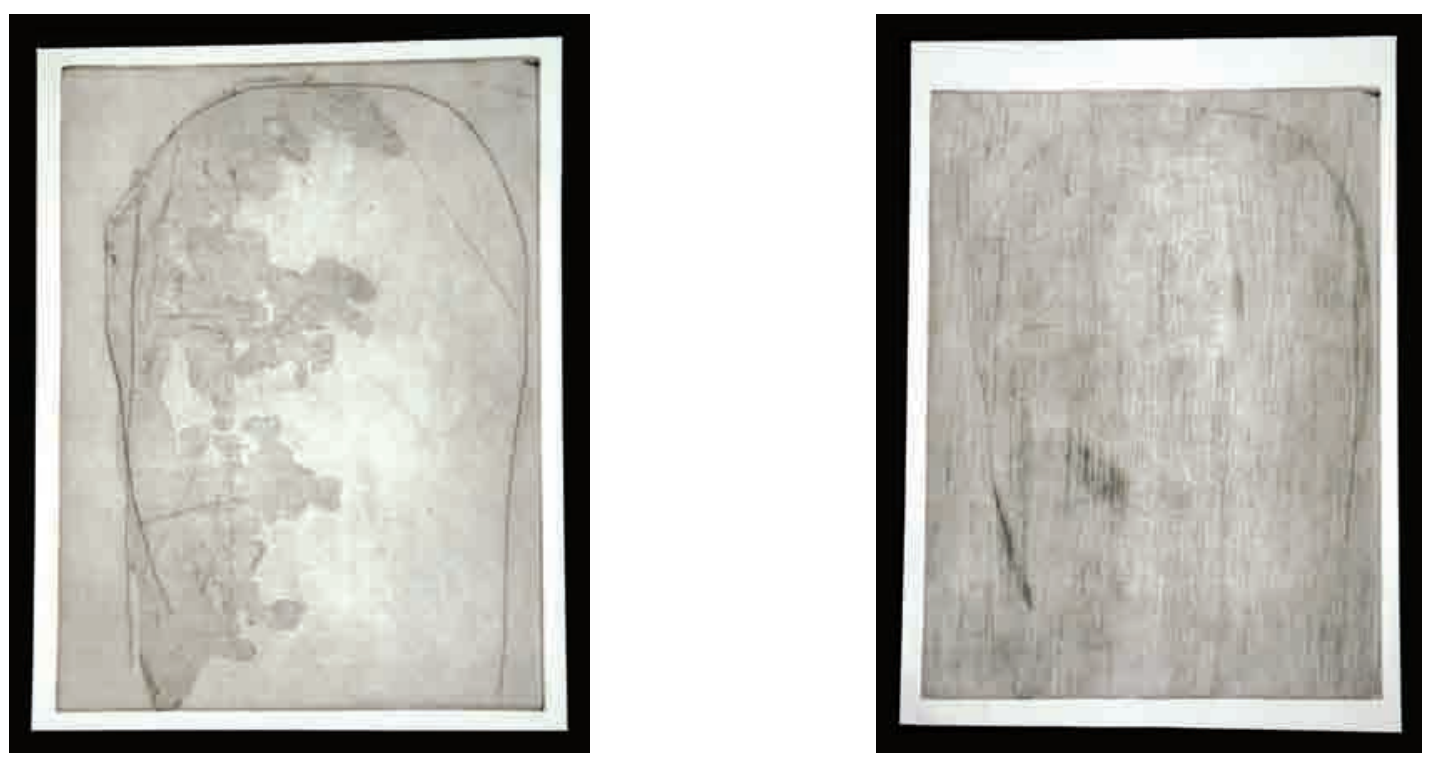

63. Retrato Frontal de Manoel, 2002
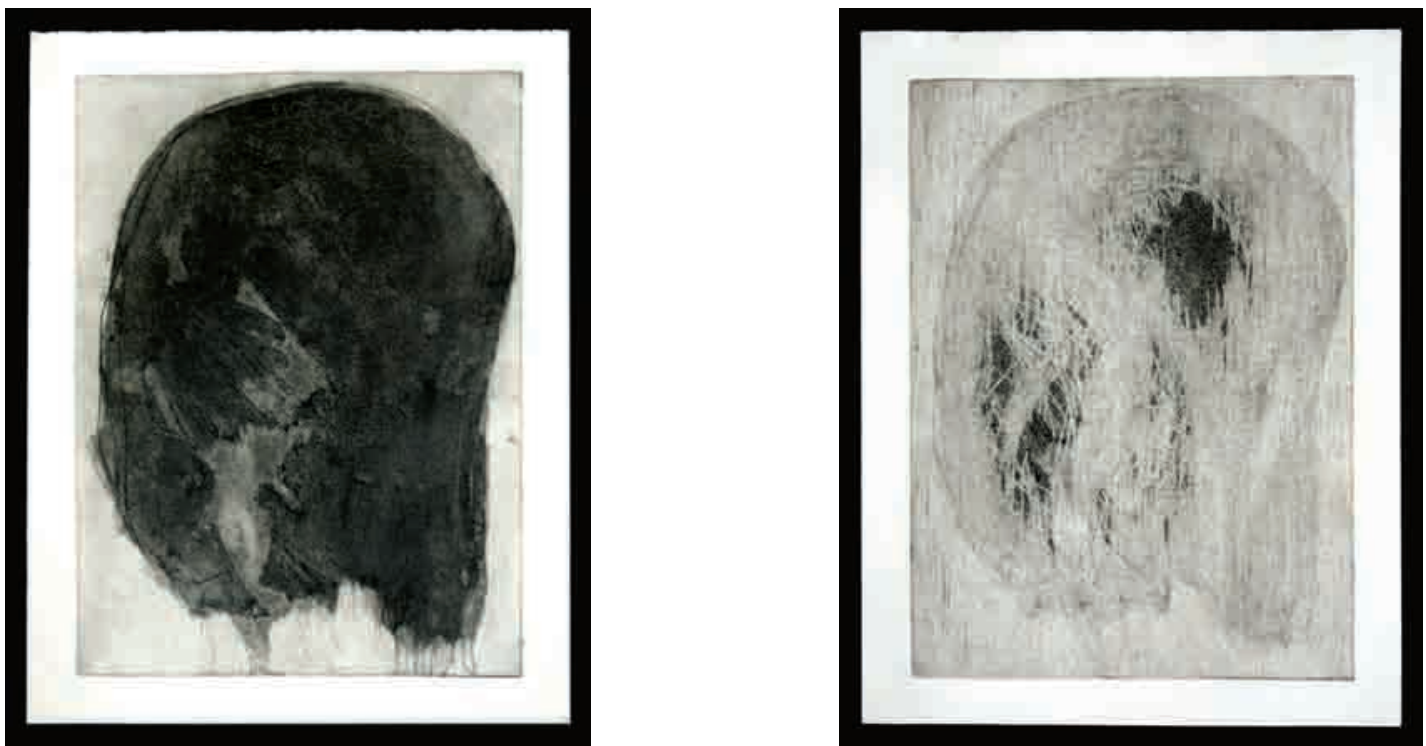

65. Retrato Lateral de Manoel, 2002 
No "Retrato de Adalgisa", as gravações pela mancha têm várias passagens e 66 a 69 construções. A princípio trabalhei com a pasta de enxofre, fazendo uma mancha relacionada à forma da cabeça, a seguir escureci toda a placa utilizando a água tinta e sobre o negro voltei a trabalhar com a pasta de enxofre, obtendo dois negros, com matérias distintas. A seguir, raspei a placa na busca de construir a figura pelas luzes que abria, até raspar a mancha quase por completo, permanecendo apenas algumas marcas, sobretudo da última mancha gravada com enxofre. 

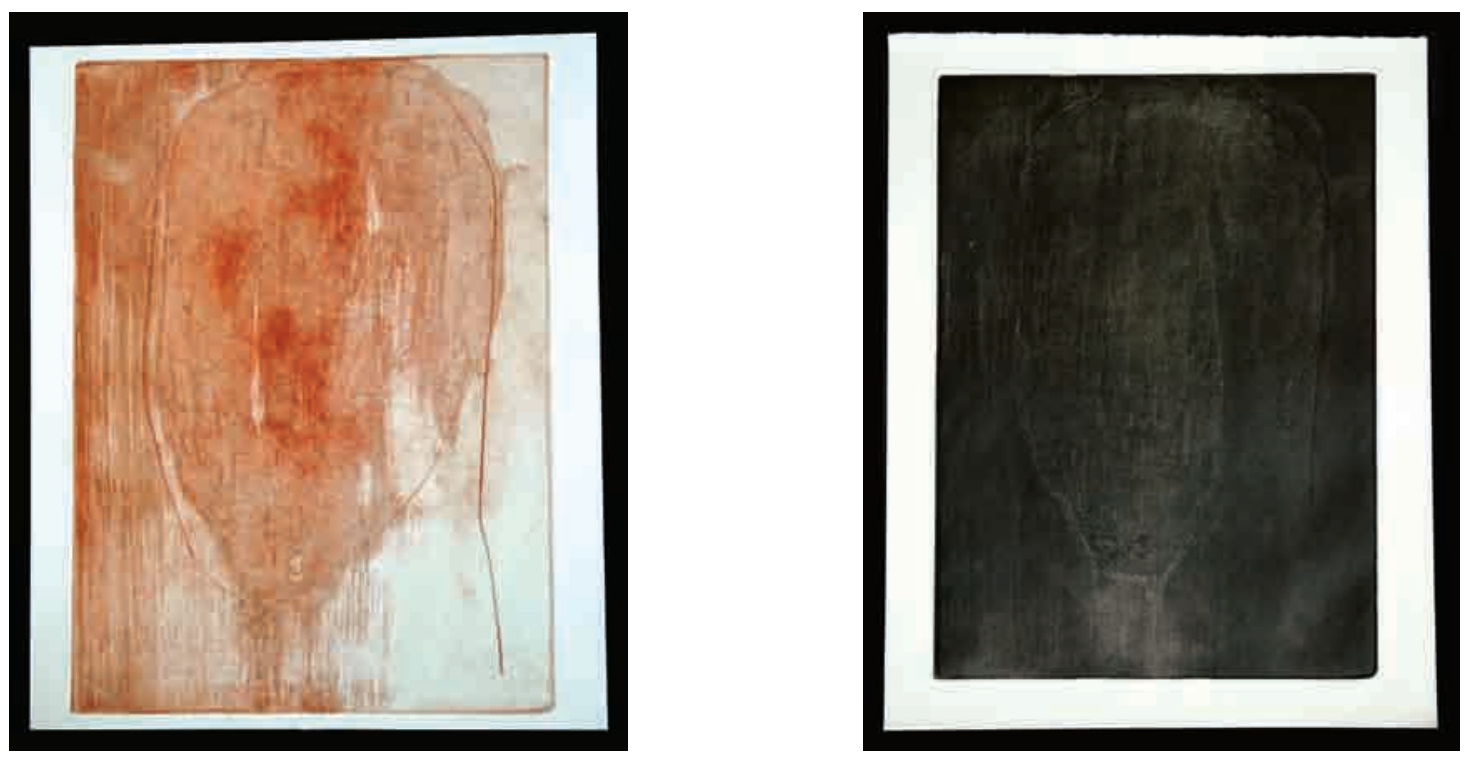

67. Retrato de Adalgisa, 2005
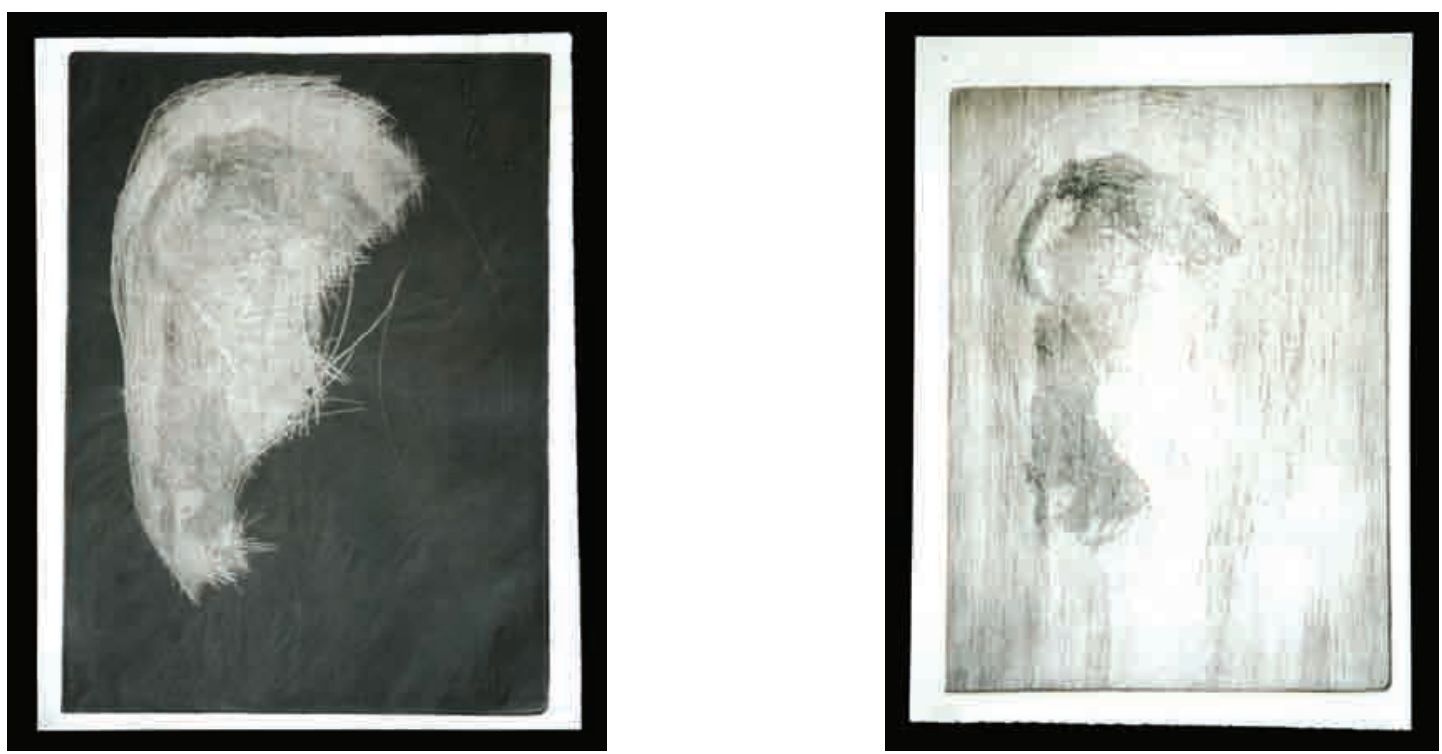

69. Retrato de Adalgisa, 2005 
Por fim, em 2005, gravei nas matrizes novas linhas em que busquei o retrato. Senti uma necessidade de torná-las mais específicas, de uma proximidade maior com a figura. Ao gravar, procurei construir linhas que portassem a figura do retratado, e se somassem às marcas que havia na matriz. Construí uma figura que emerge da placa, como uma figura da memória. Por vezes, como nos retratos de Manoel, o retrato surge em duas etapas de gravação, entre linhas que percorrem e dimensionam a face e traços de expressão fisionômica. 

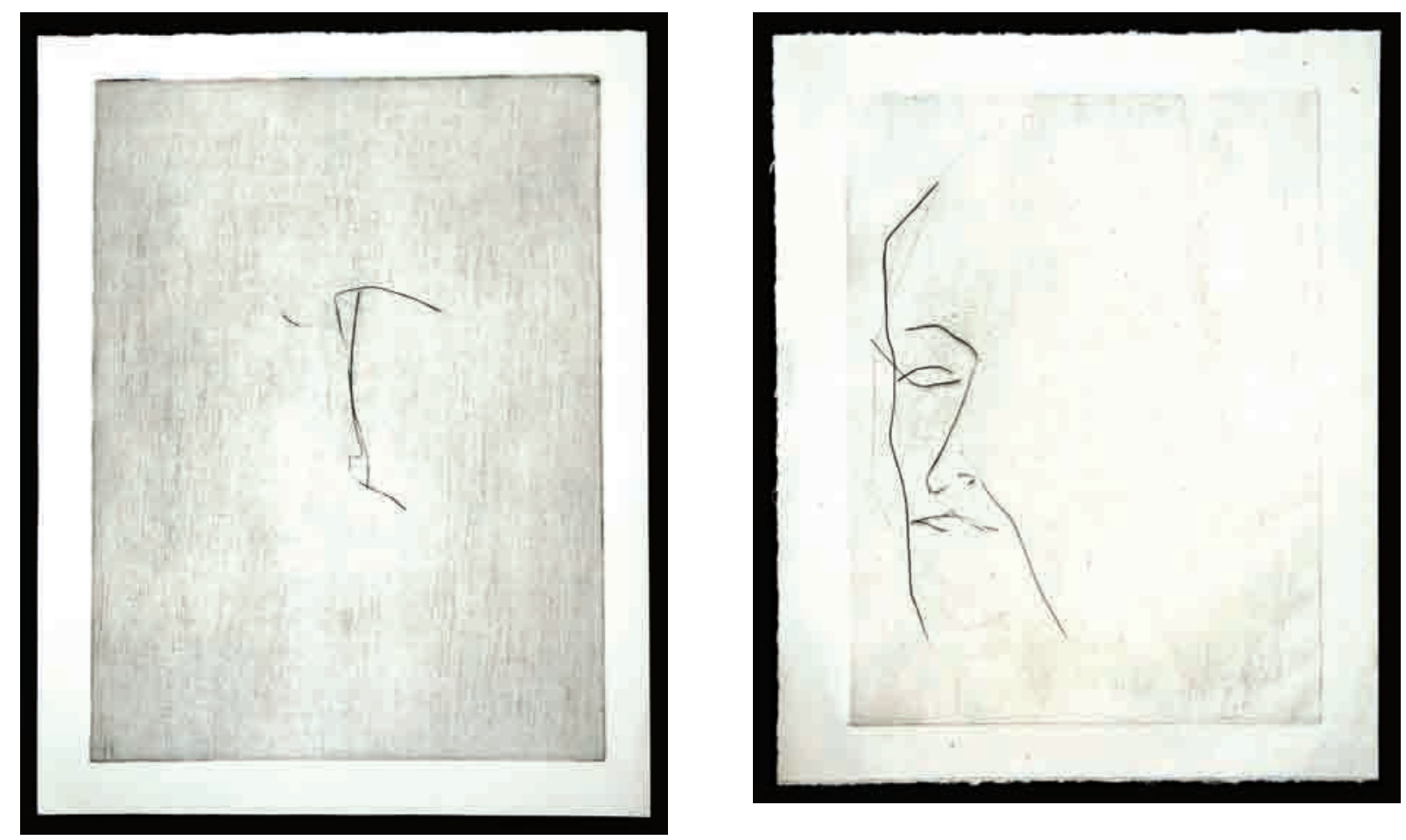

70. Retrato Frontal de Manoel, 2005

71. Retrato Lateral de Manoel, 2005 
Esta última transformação foi simultânea aos retratos feitos no mesmo período em desenhos a lápis e ponta de prata. Os conjuntos de desenhos participavam da minha memória destas pessoas e se faziam presentes nesta figura da memória que construía.

Neste processo, fiz algumas experiências em que desenhei com lápis, aquarela e monotipia sobre as provas. Estas experiências serviram muitas vezes de suporte para refletir sobre as futuras transformações sobre as matrizes, e trouxeram resultados significativos em si mesmos. Vejo estes trabalhos como momentos de reflexão sobre a forma, mas para que esta reflexão fosse efetiva, foi necessário que cada trabalho chegasse a seu limite, constituísse uma manifestação concreta. Ao empregá-los como referências para os trabalhos na matriz, nunca o fiz como modelos a serem seguidos, mas como uma reflexão sobre a forma que poderia ser cotejada com as decisões que tomava ao gravar.

Da mesma maneira, o enfrentamento com as figuras que emergiam das matrizes alimentavam os desenhos de observação. Novamente, observação e memória se sobrepõem e se justapõem no desenho, neste processo de entendimento e construção da figura. 

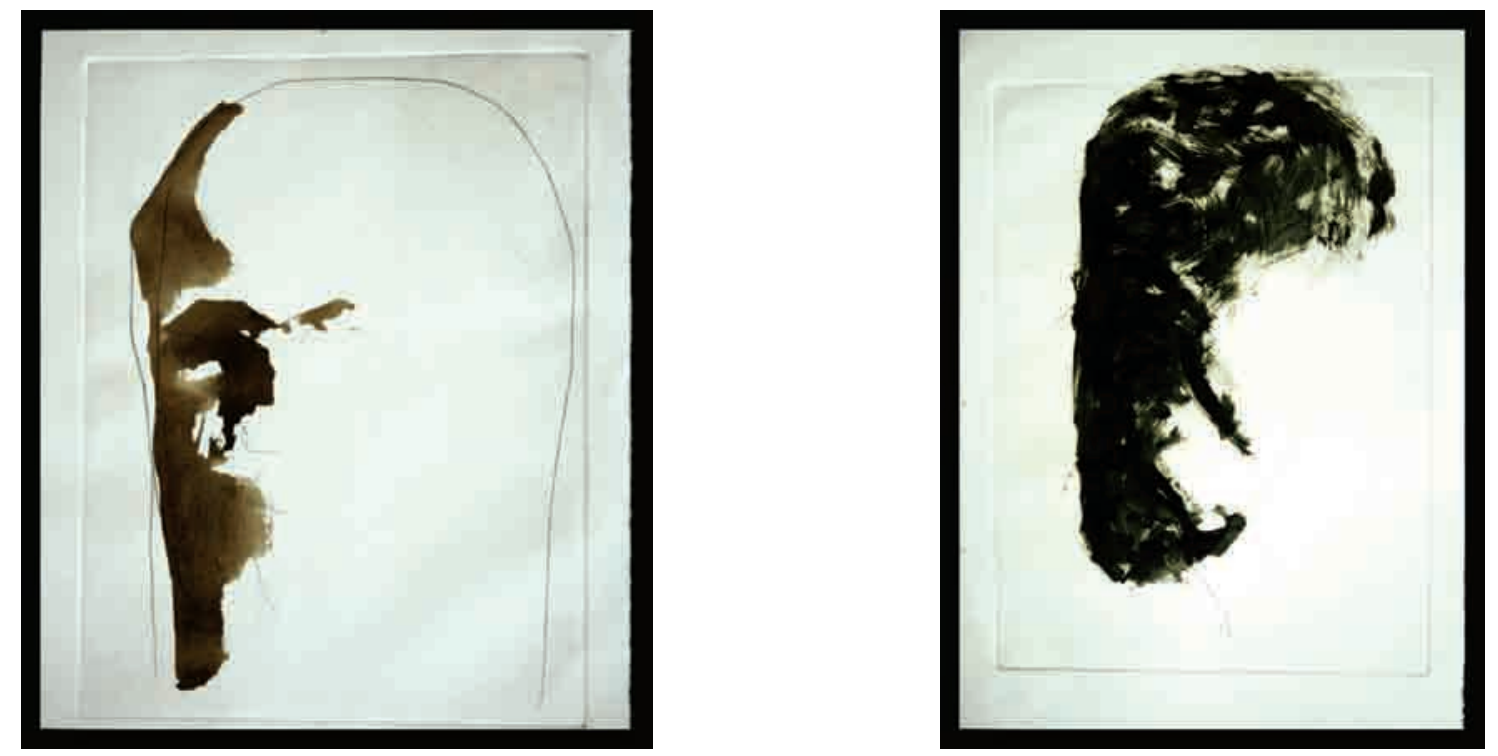

73. Sem título, 2005
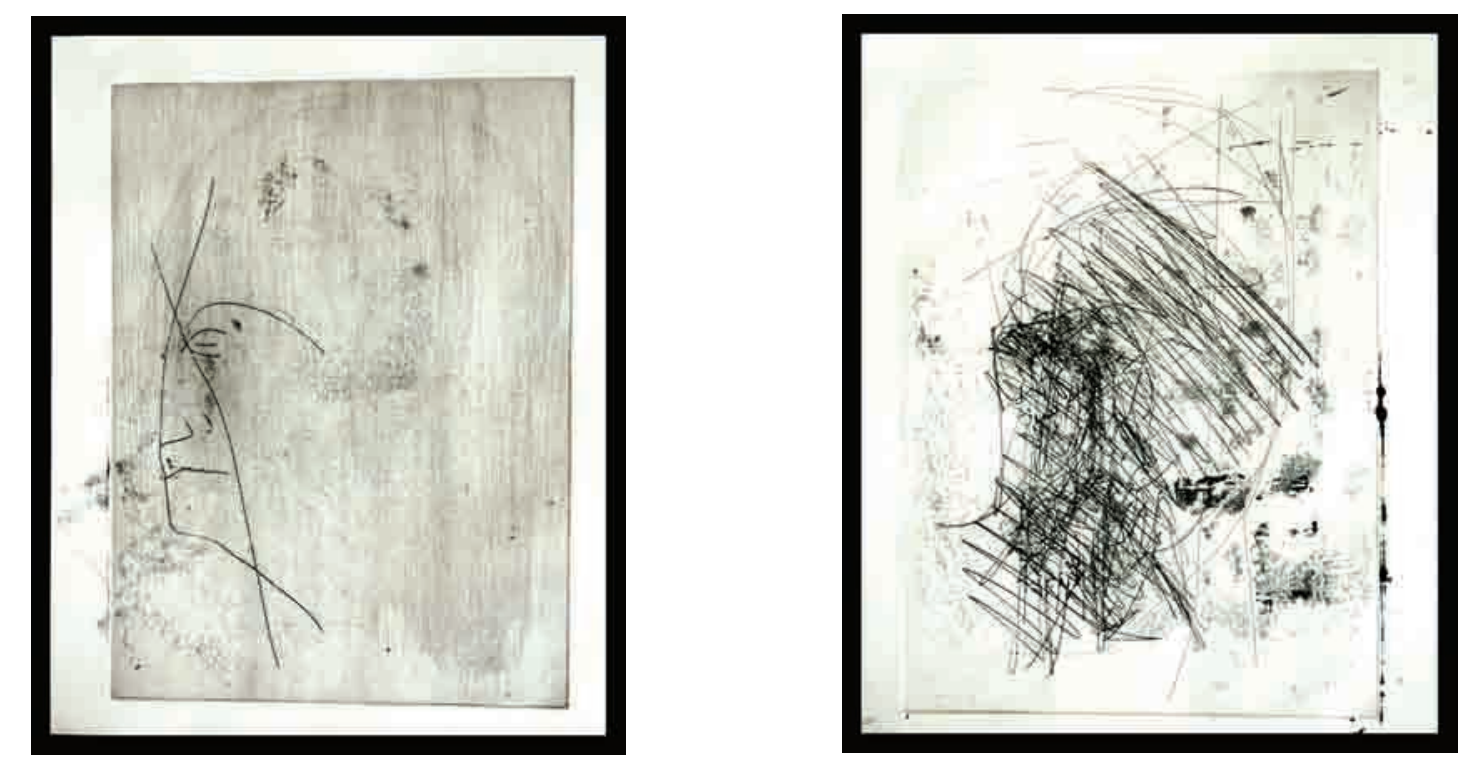

75. Sem título, 2005 
Neste processo de registrar as transformações das matrizes em sucessivas impressões, fiz experimentações com a cor, sobretudo nas gravuras construídas com a mancha, que abriram passagens para a pintura. Algumas provas sobre tecido se tornaram base para pinturas, ou foram sobrepostas por ouras impressões, na construção de retratos. 

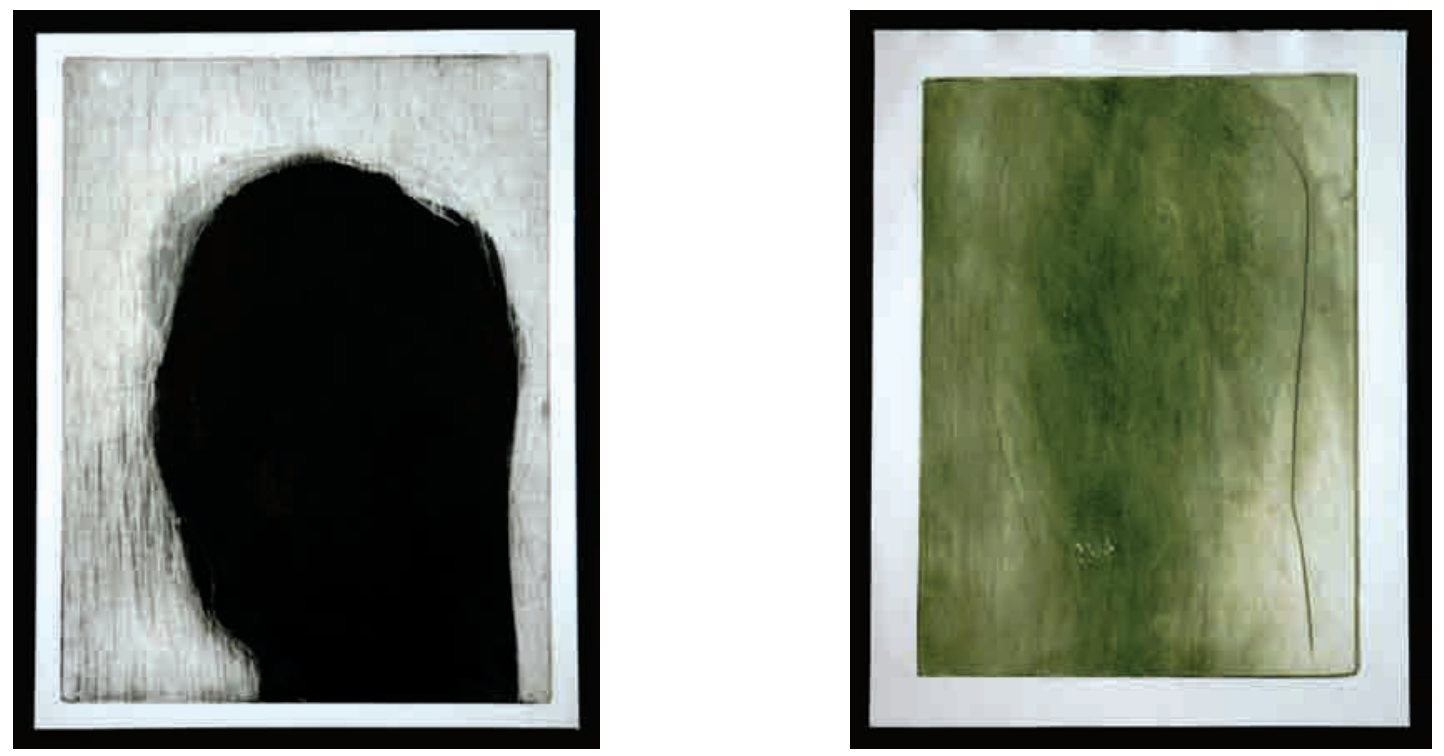

78. Cabeça que Flutua, 2004
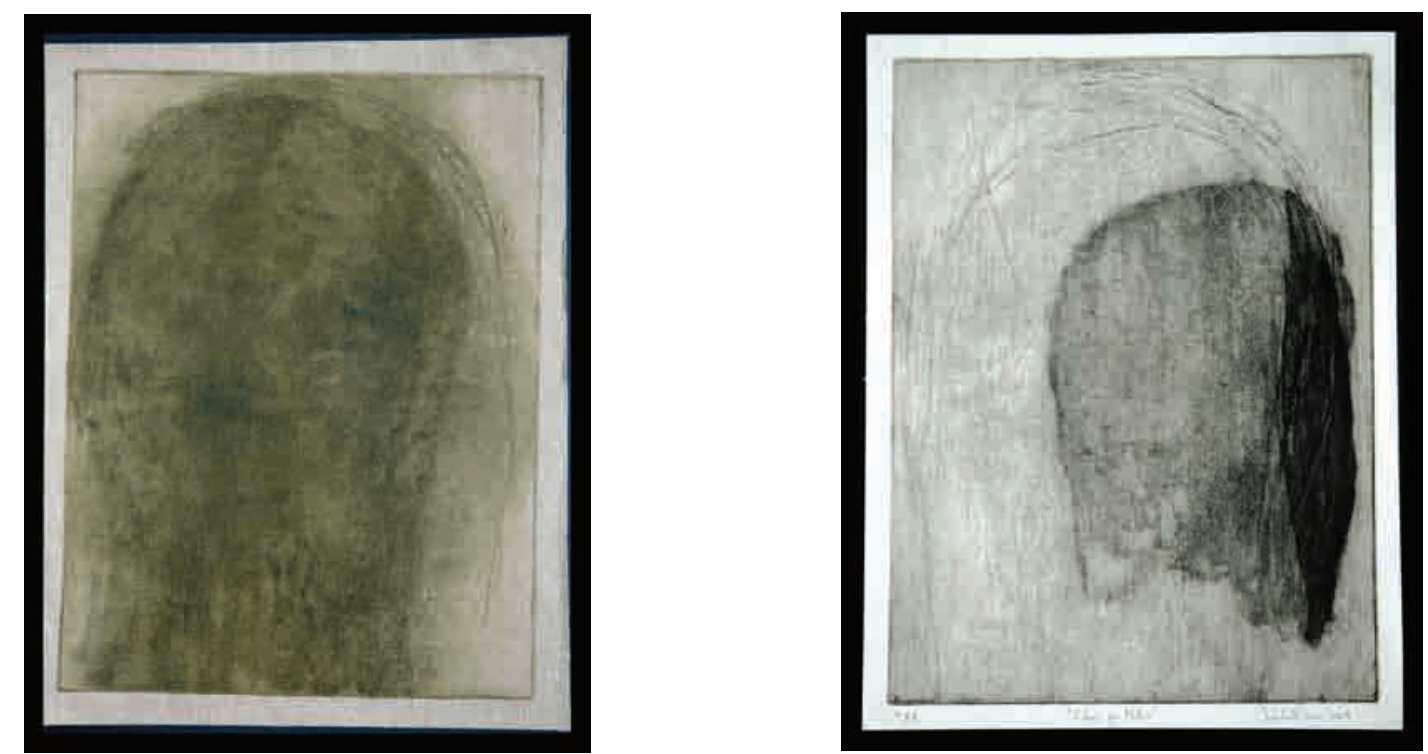

79. Cabeça que Flutua, 2004 


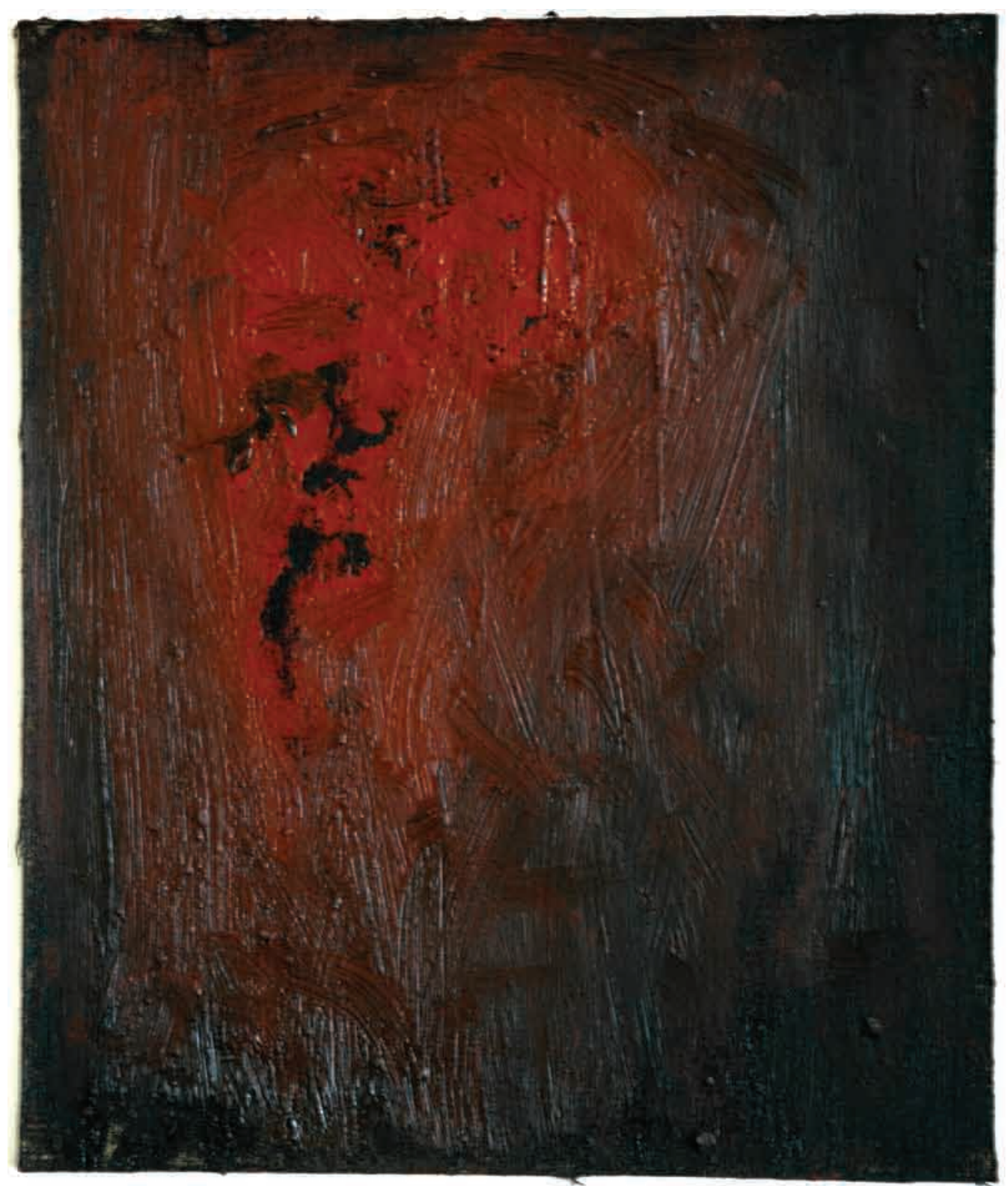


No desdobramento destas experiências, estas manifestações ganharam mais densidade, na medida em que passei a sobrepor as impressões, de estados diferentes da mesma ou de distintas matrizes. No "Retrato de Manoel" imprimi a matriz de seu retrato lateral em terra de sombra sobre uma impressão em vermelho da matriz de seu retrato frontal, em uma configuração anterior. No "Retrato de Adalgisa", estão sobrepostas, em vermelho e verde, a configuração atual e um estado anterior da mesma matriz. Estes dois trabalhos são feitos sobre linho, e tanto a cor quanto a matéria do linho participam de sua forma. Quando a cor passa a ser constitutiva da forma, quando lhe é intrínseca e necessária, eu creio que seu emprego é significativo, mas quando esta se manifesta como algo que "enfeita" o desenho, deve ser descartada. Nestes dois retratos, apesar de já ter as impressões em negro, e considerá-las suficientes, a experiência com a cor trouxe uma nova manifestação a partir das mesmas matrizes, que é significativa em sua materialidade e temporalidade. Pela sobreposição das impressões, inseri de uma nova maneira as sucessivas transformações das matrizes neste processo. O registro de um estado anterior participa de uma nova configuração do retrato, estabelecendo outras relações entre matéria, cor e forma, e de temporalidade, através da sobreposição de distintos tempos da construção de uma figura. Esta manifestação temporal reverbera no conjunto dos retratos, e se torna mais complexa pela possibilidade da sua exposição simultânea. 


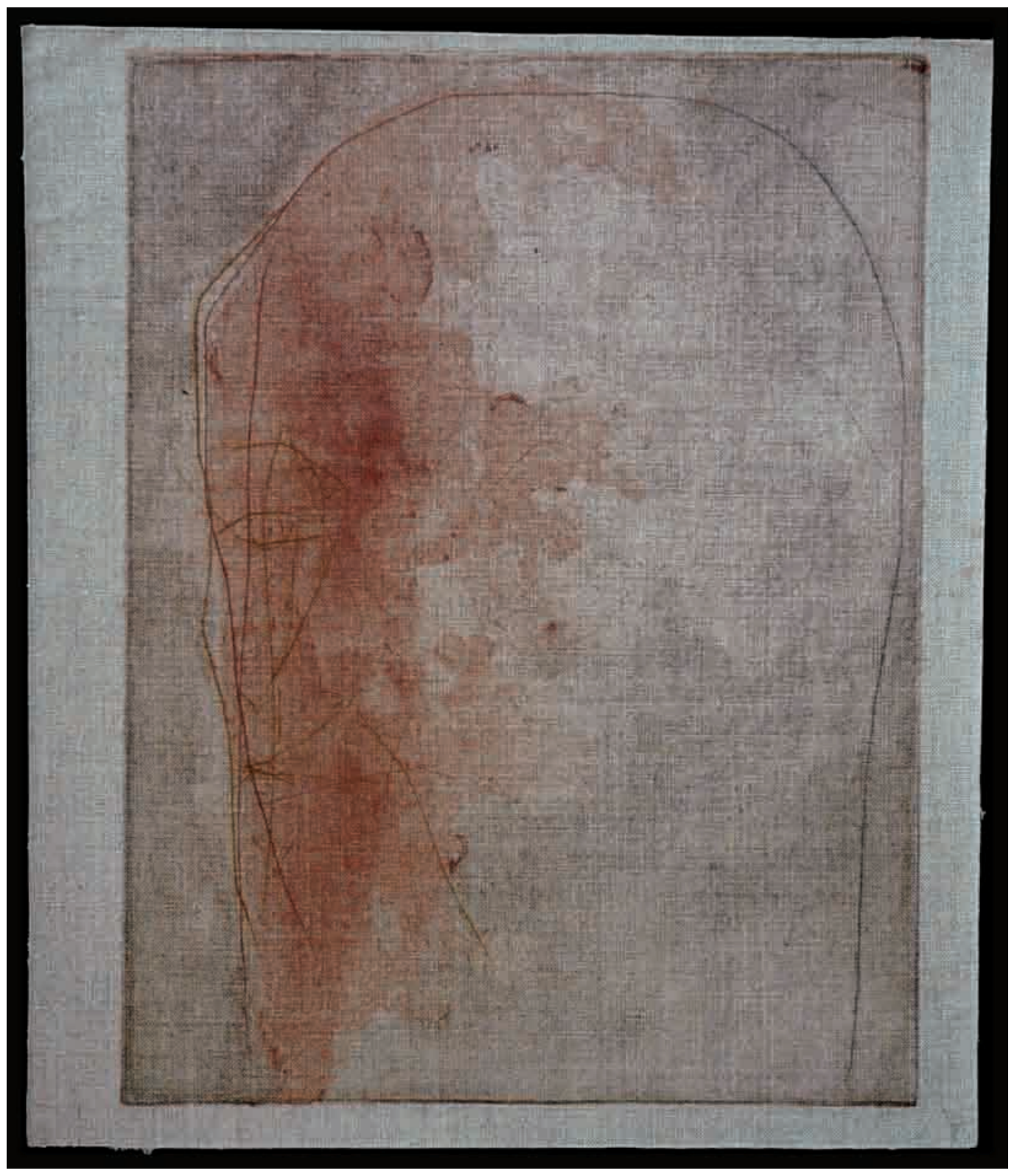




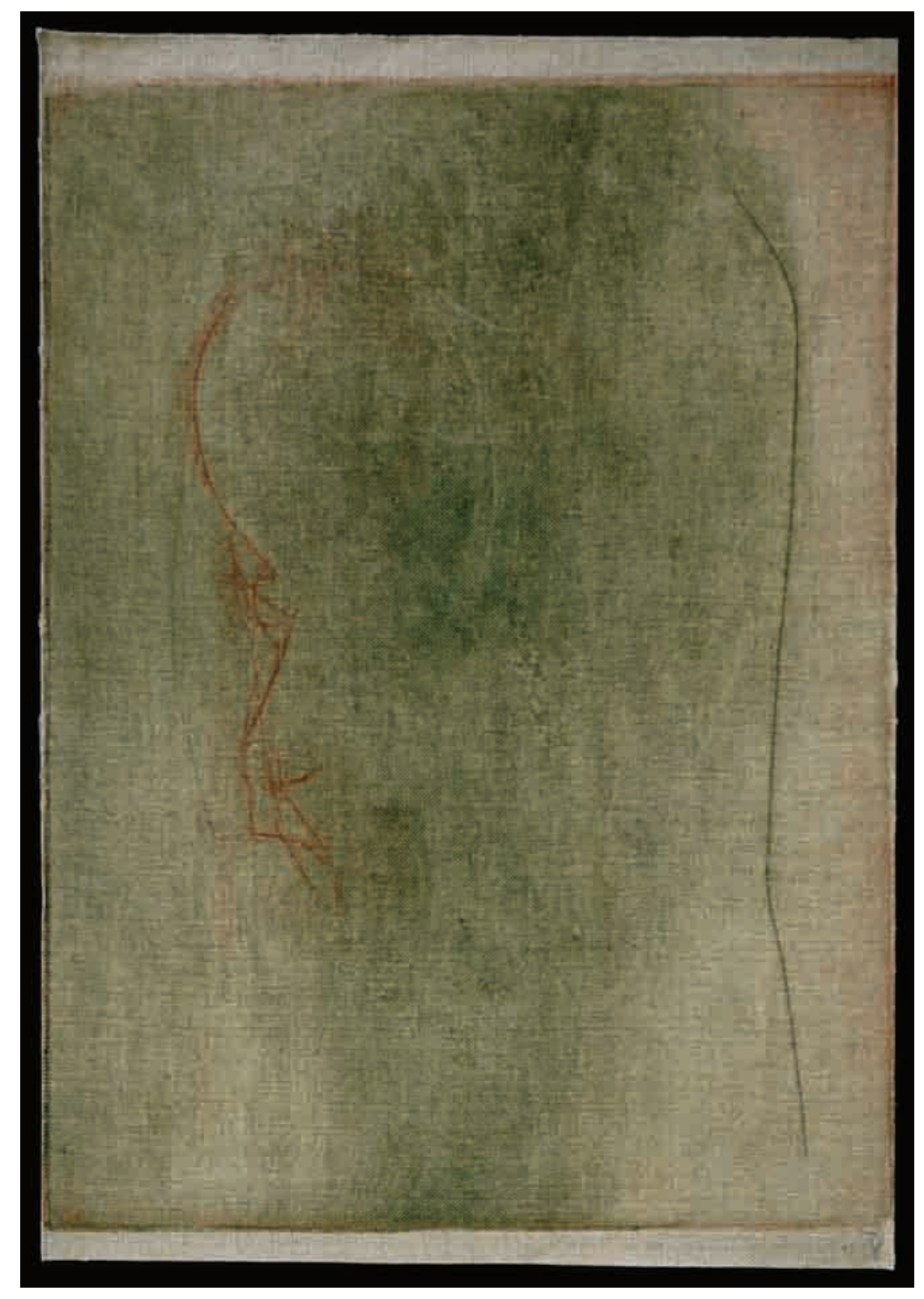


"Dois Retratos de Manoel" e "Dois Retratos de Manoel Lendo." Estas duas gravuras foram feitas de observação, assim como os desenhos a grafite e ponta de prata sobre papel e partilham da mesma temporalidade, de um retrato que se propõe como apreensão de um instante diante da pessoa retratada pela presteza no desenho de seus traços singulares. Foram gravadas com a ponta seca em gestos rápidos e diretos, sobre uma placa não polida, e na impressão as marcas preexistentes na placa se somam às linhas gravadas. Os títulos se referem a duas situações distintas nas quais fiz os retratos, no primeiro, observei frontalmente o retratado que me fitava e no outro o observei enquanto lia e em ambos, fiz dois retratos justapostos, o que os torna retratos que apresentam simultaneamente dois instantes. 


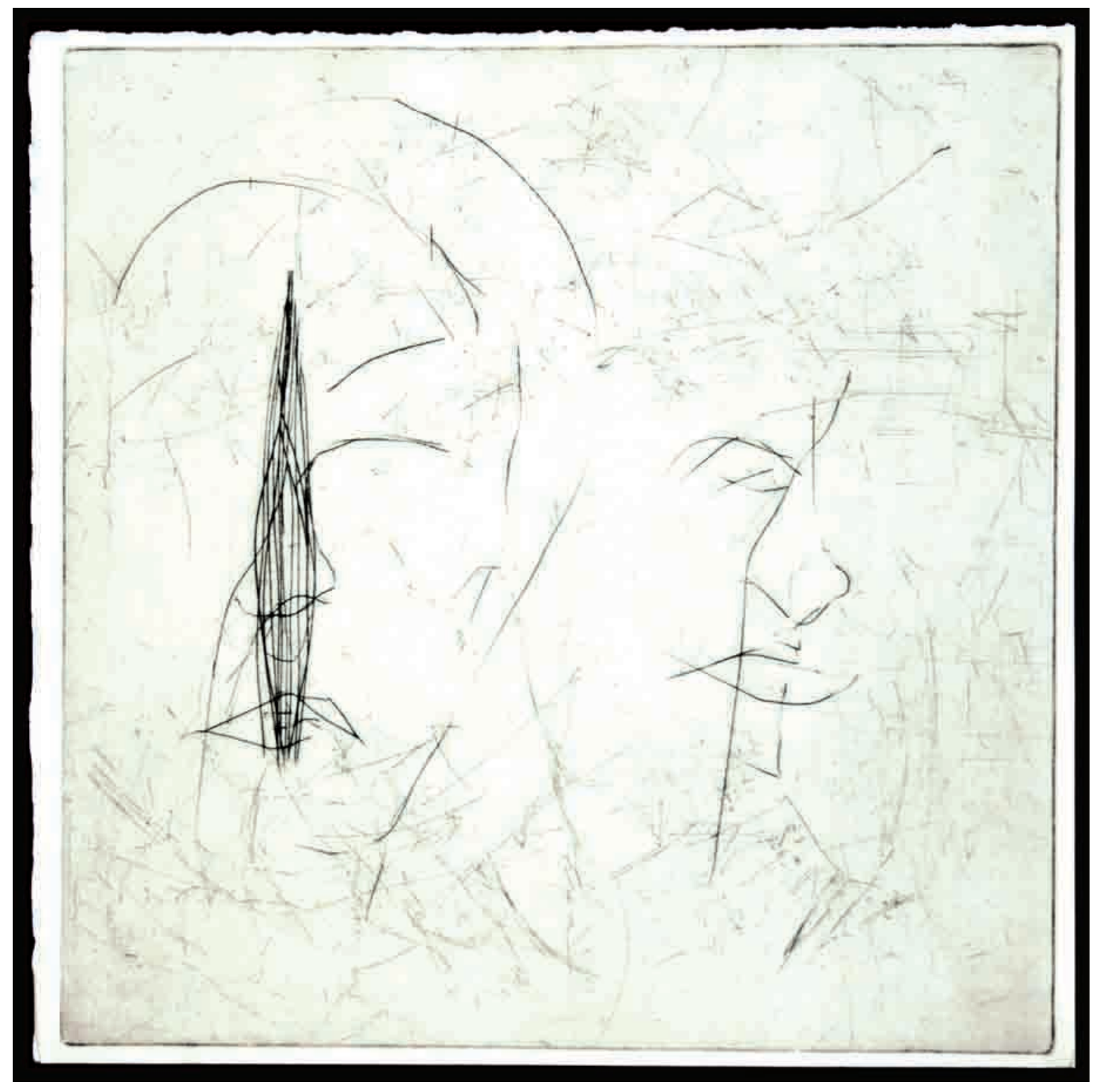

83. Dois Retratos de Manoel, 2006 
Esta temporalidade que enfatizo se relaciona com o fato de serem retratos "de observação", tornando-os distintos das outras gravuras analisadas anteriormente, em que o retrato foi feito "de memória". Determinante para esta diferenciação é a presença do retratado diante de mim no momento em que desenho, estabelecendo uma distância, física e temporal. Mas estas categorias, da observação e da memória, se sobrepõem. Nos retratos de observação, sempre há a incidência da memória, ainda que no breve instante entre os atos de observar e desenhar, e sobretudo, na eleição pelo desenho do que eu quero retratar e como retratar. Igualmente, nos retratos "de memória", a observação se faz presente, mesmo que na ausência do retratado, por meio de outros desenhos e sobretudo pelo que elegi guardar comigo. Ao eleger determinadas linhas na construção de um retrato, estabeleço neste desenho uma memória, e torno sua figura presente.

Neste sentido, a memória se projeta em direção a eventos passados e futuros, como aquilo que posso reter e projetar, traços que permanecem de uma identidade. Esta temporalidade sempre se atualiza no desenho, que lhe confere uma dimensão concreta do devir, presente e aberto a cada manifestação. 


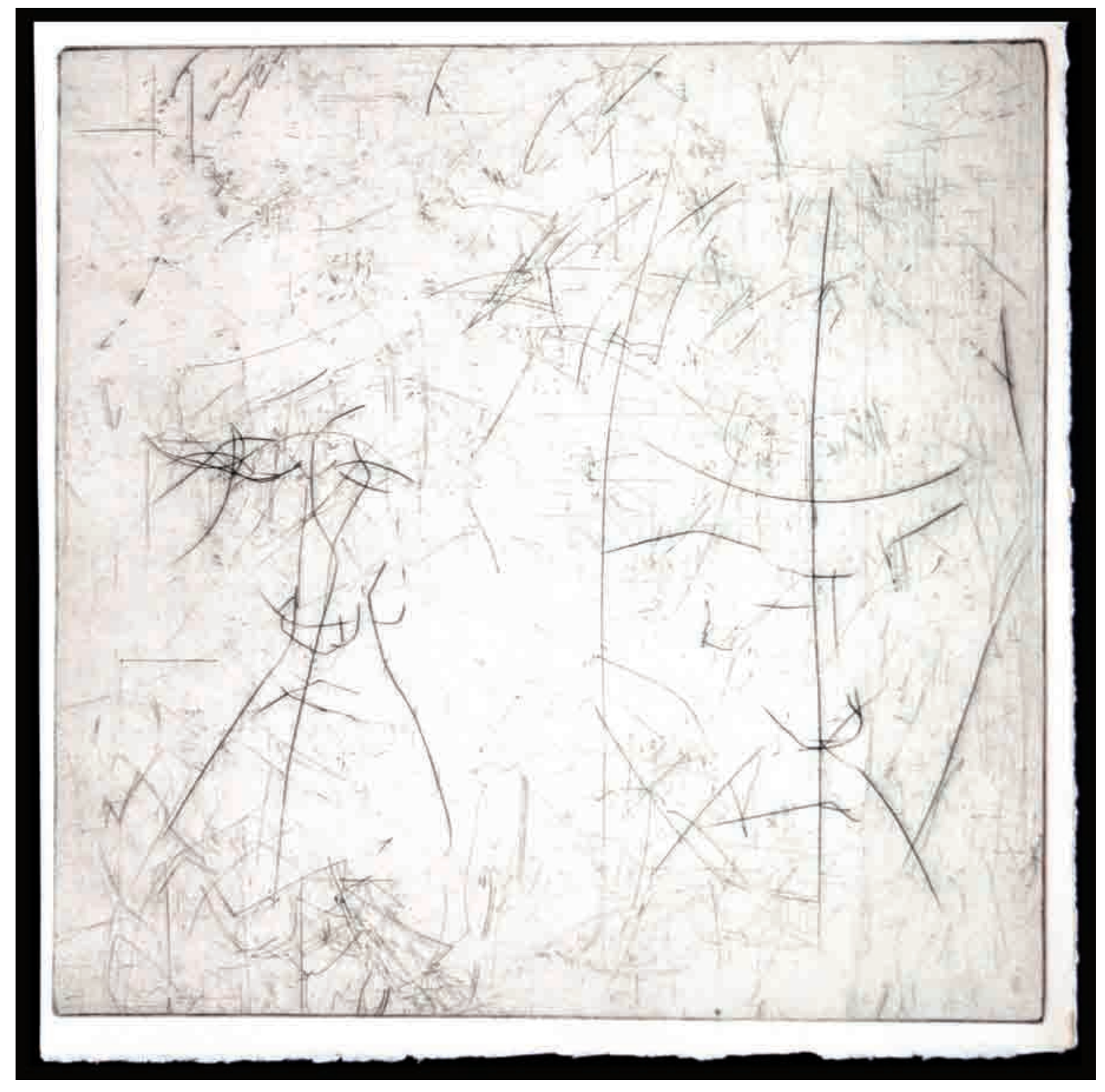


O "Retrato Caligráfico de Adalgisa" também se constituiu pela justaposição de uma série de desenhos na mesma placa, gravada pelo procedimento da água forte, em etapas sucessivas, em linhas cursivas, caligráficas. Nas gravações, os desenhos da face em distintas posições se adensaram e se fundiram por meio de tramas lineares. $O$ retrato se concretiza neste desenho, em que se diferenciam e se fundem momentos e vistas distintos da mesma face. 


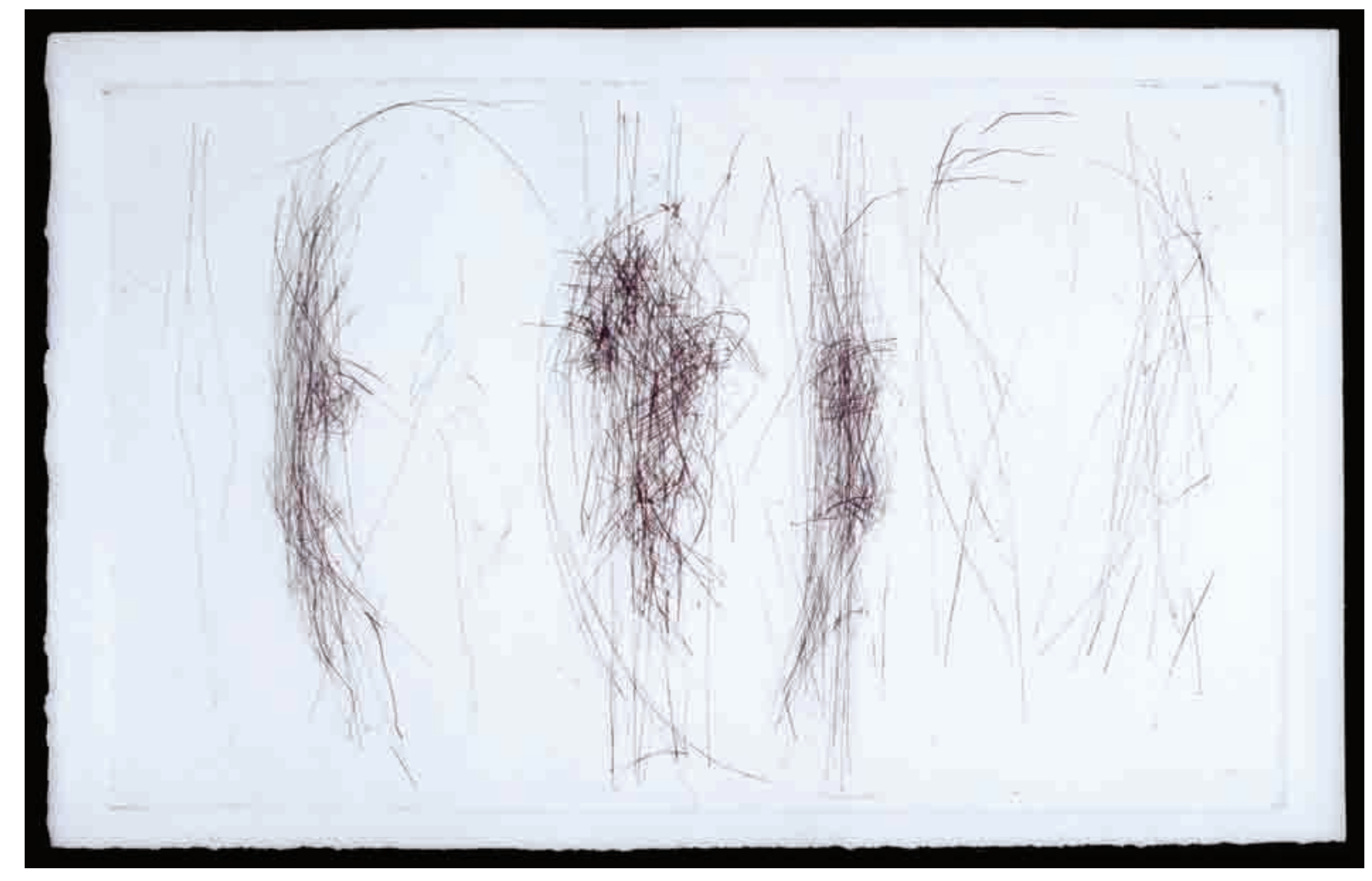

85. Retrato Caligráfico de Adalgisa, 2006 
Outros retratos tomam forma por meio de tramas lineares, constituindo massas pelas quais posso referir à identidade da pessoa retratada. Para estes trabalhos foi fundamental que a trama atingisse uma determinada densidade, proporcionando peso e força à forma, mantendo a coesão entre as linhas, as massas e as luzes que emergem em seu interior e entorno. A forma reside nesta relação intrínseca entre as massas e as luzes, construídas ao mesmo tempo pelas tramas lineares. O equilíbrio entre cheios e vazios, entre o que foi gravado e a superfície do metal é estrutural desta forma, assim como os pesos, as espessuras e profundidades das linhas. As gravuras foram construídas em gravações sucessivas, e neste percurso, o emprego de diferentes procedimentos, materiais ou tempos de gravação implicou diretamente na qualidade das linhas, e por conseguinte, da forma. 


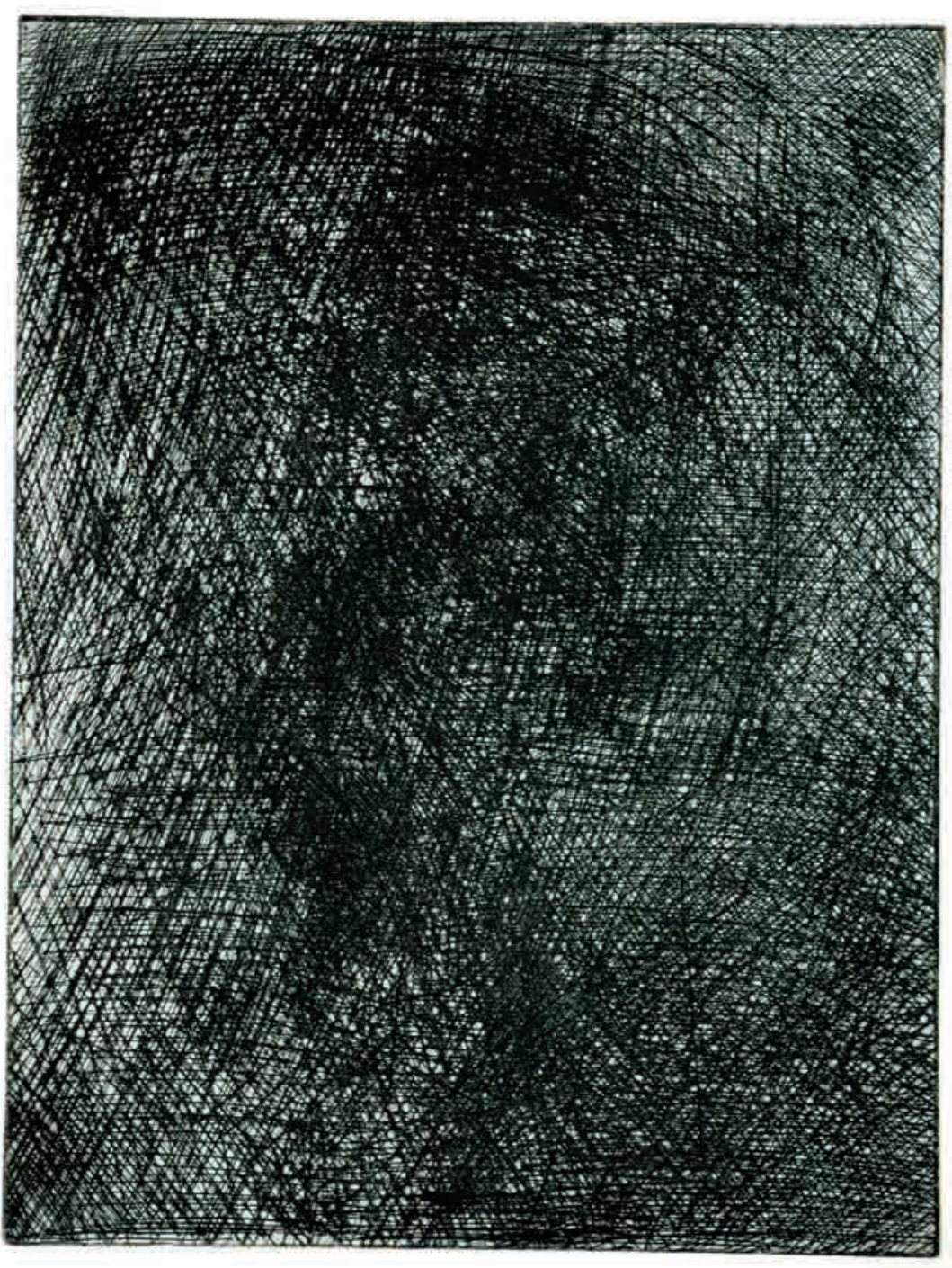


O "Retrato Trama de Maria Helena" partiu de uma gravação a buril, que enfatizava a estrutura de uma cabeça, por meio de linhas que a atravessavam. Nesta gravura já havia linhas que indicavam traços fisionômicos, e senti a necessidade, na medida em que trabalhava com os retratos, de transformá-la, de torná-la mais específica, de maior proximidade. Como se o retrato passasse a exercer uma espécie de força gravitacional atraindo as gravuras para este território, como se desafiasse as matrizes já gravadas a ir mais adiante. Vislumbrei nesta cabeça um possível retrato de Maria Helena, em parte pelos traços já gravados, em parte pelo seu cotejamento com desenhos a lápis. Procurei então pela construção de tramas lineares me aproximar deste retrato. Após as primeiras regravações, senti que deveria tomar um caminho em que o retrato não se estabeleceria em traços fisionômicos, mas por meio da sua forma constituída na correspondência entre as massas e luzes, que poderiam evocar a pessoa retratada. 

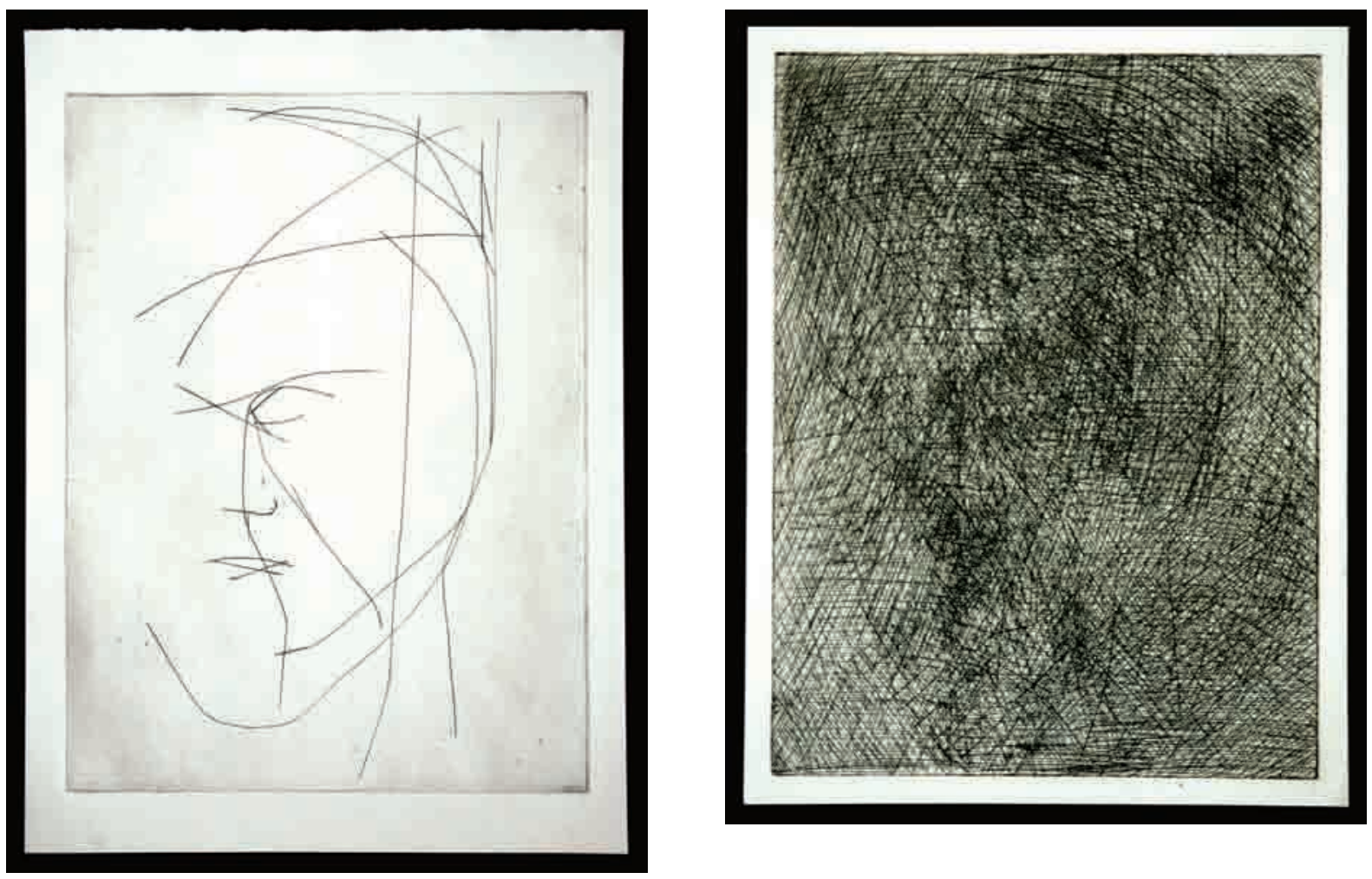

87. Retrato Trama de Maria Helena, 2001

88. Retrato Trama de Maria Helena, 2005 
Ao compararmos esta gravura ao "Retrato Trama de Manoel", é possível notar uma diferença na espessura das linhas, além do fato de a trama ser mais densa nesta gravura, na qual adotei um diferente procedimento ao eleger um verniz sólido para as regravações. Este verniz permite que várias gravações possam se suceder sem que o mordente invada e altere as linhas gravadas anteriormente. Para atingir a densidade necessária nesta trama, sem destruir as linhas anteriores e a própria trama, a escolha deste verniz foi fundamental. 


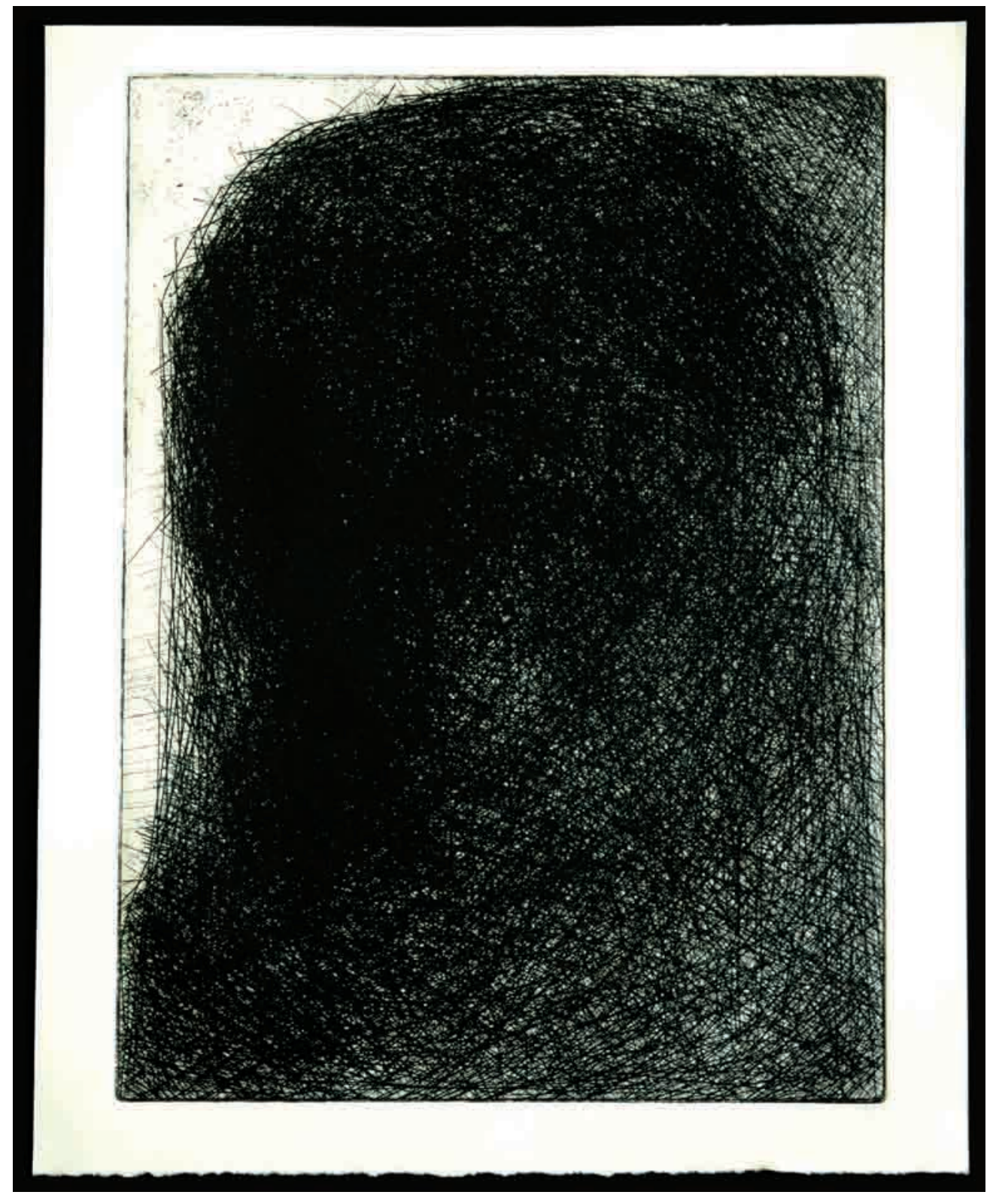


Outro aspecto importante é o dos tempos das gravações, por serem distintos, conferem profundidades diferentes às correspondentes tramas lineares gravadas, o que implica diretamente em sua construção luminosa, e evidencia um caráter fundamental da relação entre massas e luzes que constituem estas gravuras: estas massas são construídas em relevo, à profundidade e espessura das linhas gravadas corresponde o corpo das linhas impressas, e consequentemente a sua luminosidade. A eleição e condução dos procedimentos é uma operação do desenho, enquanto construção necessária para cada figura. No "Retrato Negro de Manoel", intercalei gravações com ponta seca e água forte, o que também implica na qualidade de sua trama linear e da intensidade da luz que emerge no seu interior. 
90. Retrato Trama de Manoel, 2002
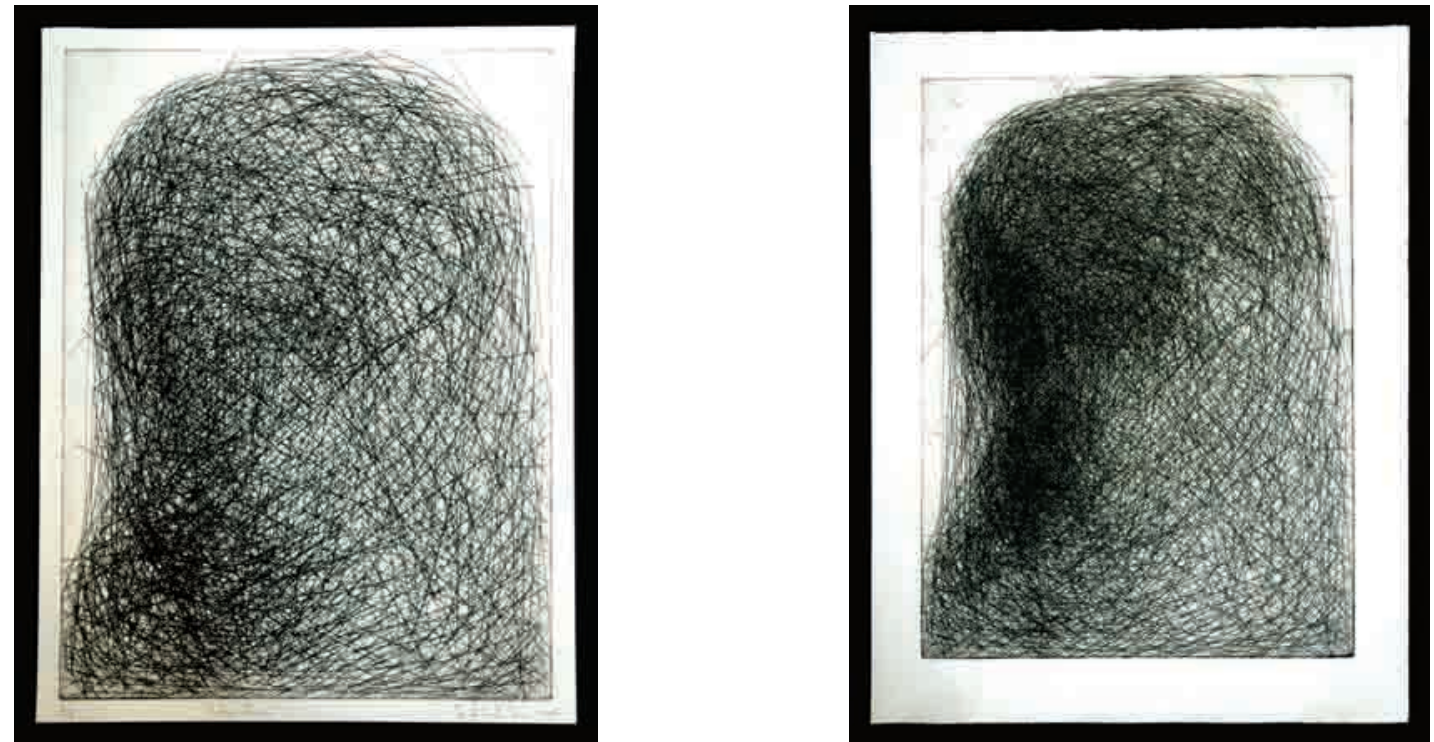

92. Retrato Negro de Manoel, 2004
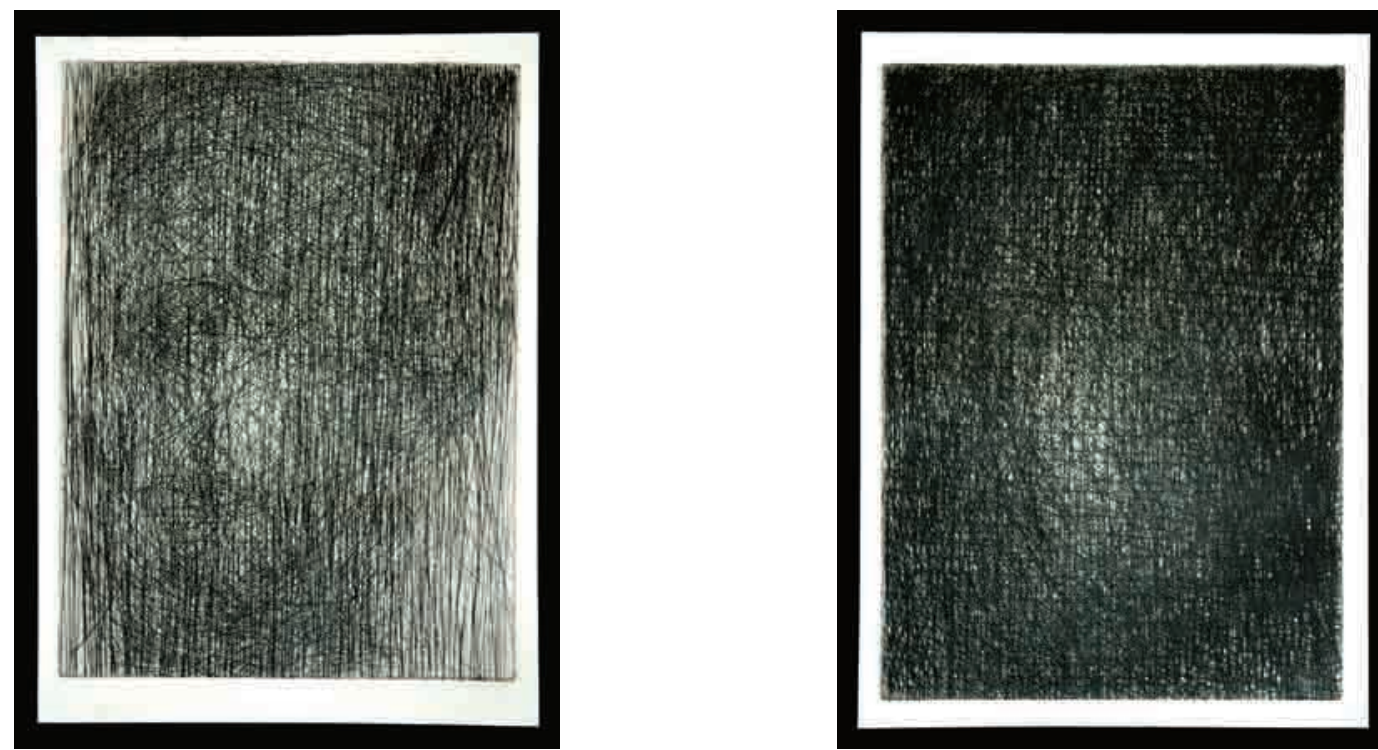

93. Retrato Negro de Manoel, 2004 
O retrato, nestas gravuras, se constitui nesta contraposição entre a luz que salta e a profundidade da massa escura, e pela tensão entre estes movimentos, de submergir e emergir de seu interior. 


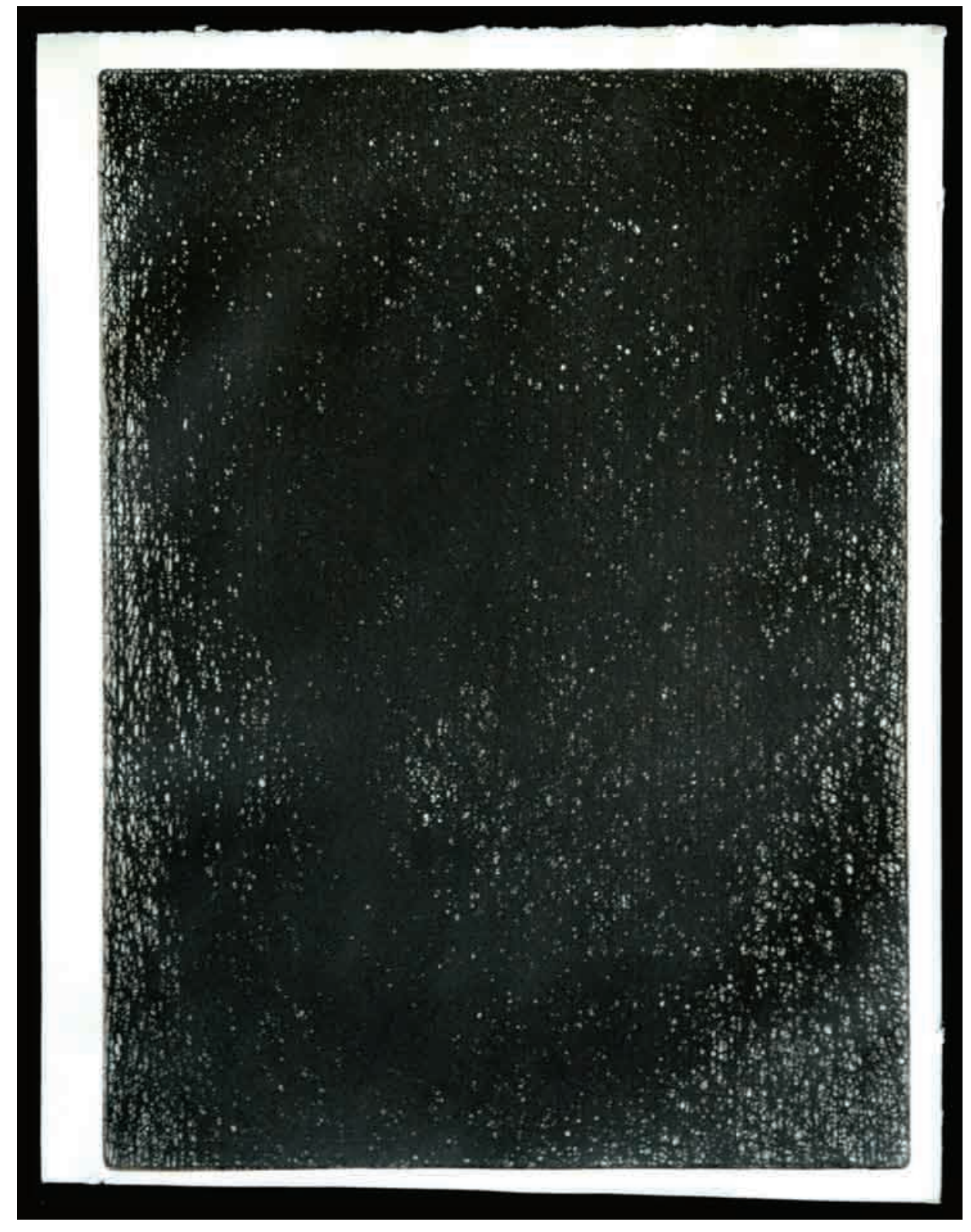


Fiz ainda uma série de retratos por meio da xilogravura. Nestas xilogravuras, a figura emerge pelo corte na madeira que se manifesta como luz e porta traços fisionômicos dos retratados. No "Retrato de Manoel", ou no "Retrato de Adalgisa", a figura emerge nesta tensão entre o corte e a superfície, entre luzes e massas, e o equilíbrio entre estes elementos é intrínseco à sua forma. 


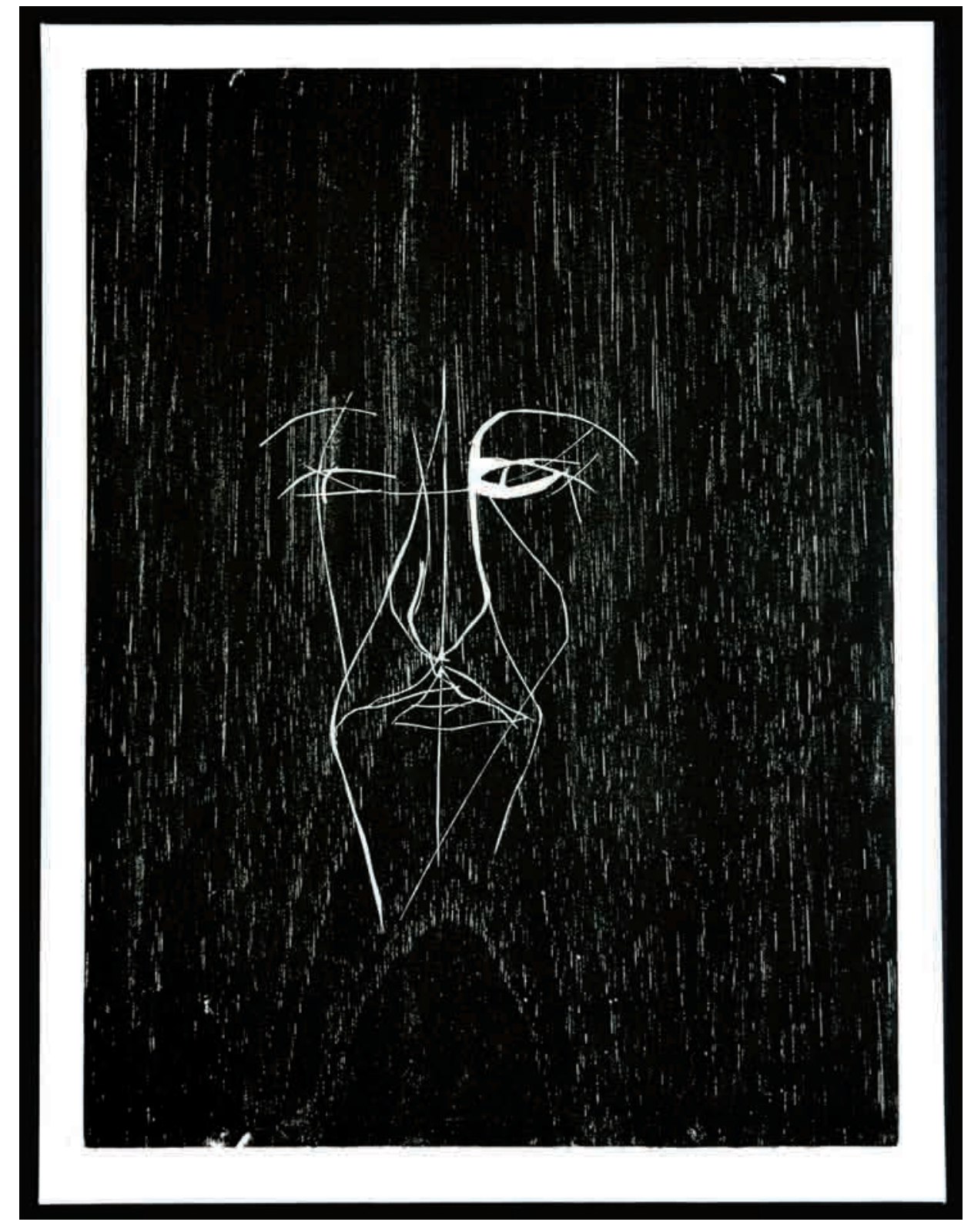




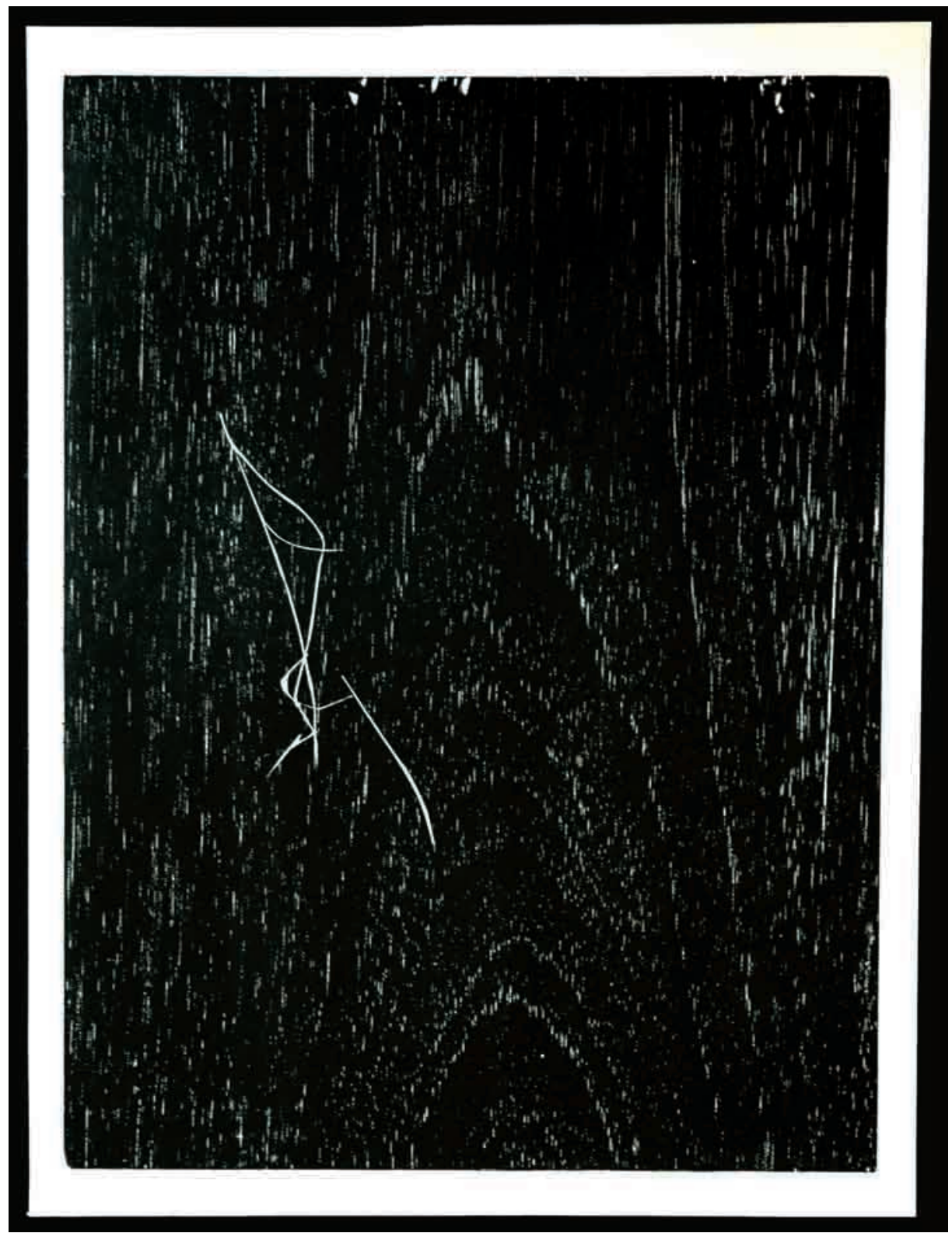


A textura da madeira também é incorporada ao desenho, pela relação que se estabelece entre a luz dos veios quando impressos com a luz dos cortes, como fica evidente no "Retrato Oblíquo de Manoel". 


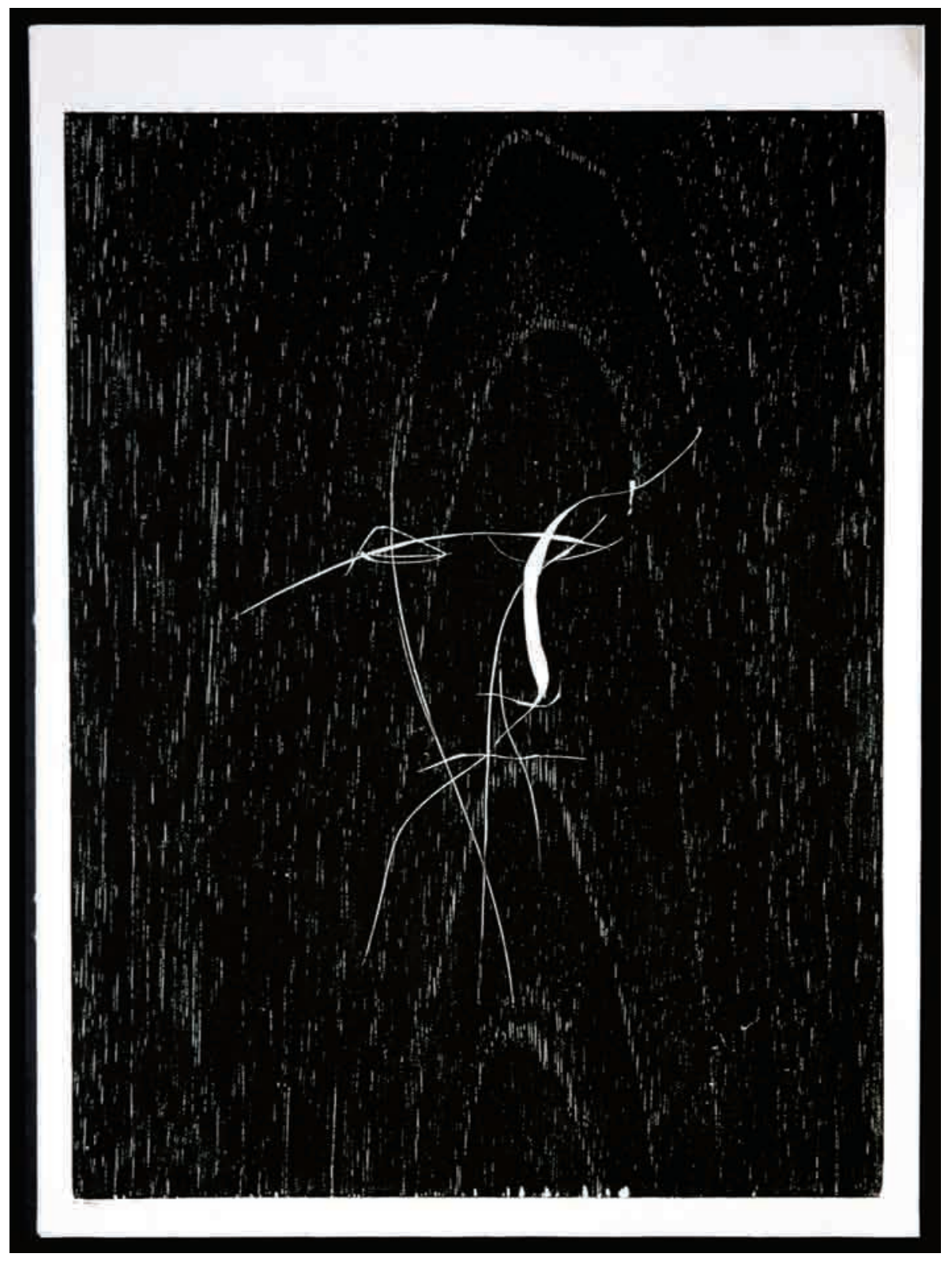


Em alguns trabalhos, partindo das linhas, abri mais a matriz, construindo uma luz mais intensa, o suficiente para que saltasse a figura. Este ponto em que a figura se torna presente, e nela o retratado, é também um ponto de equilíbrio, em que gravar além significa perder a figura, ou o instante de sua manifestação, mesmo que por novas gravações eu pudesse descrever melhor a fisionomia da pessoa retratada. $O$ retrato emerge pela busca deste momento em que a figura se faz presente e torna possível um encontro, um reconhecimento.

A presença destes retratos reside em sua evidência, na clareza de construção na qual convergem traços e luzes, pela eleição do que gravar e do que deixar intocado na matriz. Esta eleição implica em como a figura se apresenta, o que retirei em sua observação e memória, o que permanece. Ao eleger traços precisos para figurá-la, necessariamente relevo outros. Assim como a evidência das linhas reverbera no vazio, como as luzes saltam das massas escuras, a figura reside na concretude destas marcas e na ausência de outras, nas escolhas feitas no processo de trabalho. A construção de uma figura, como memória, implica em permitir que esta também se afaste, ao renunciar a alguns de seus aspectos para tornar outros evidentes. Sua presença implica em sua ausência. Neste movimento, traços se evidenciam e se abrem, evocam o tempo de um encontro que já se perdeu, e suscitam outros. 


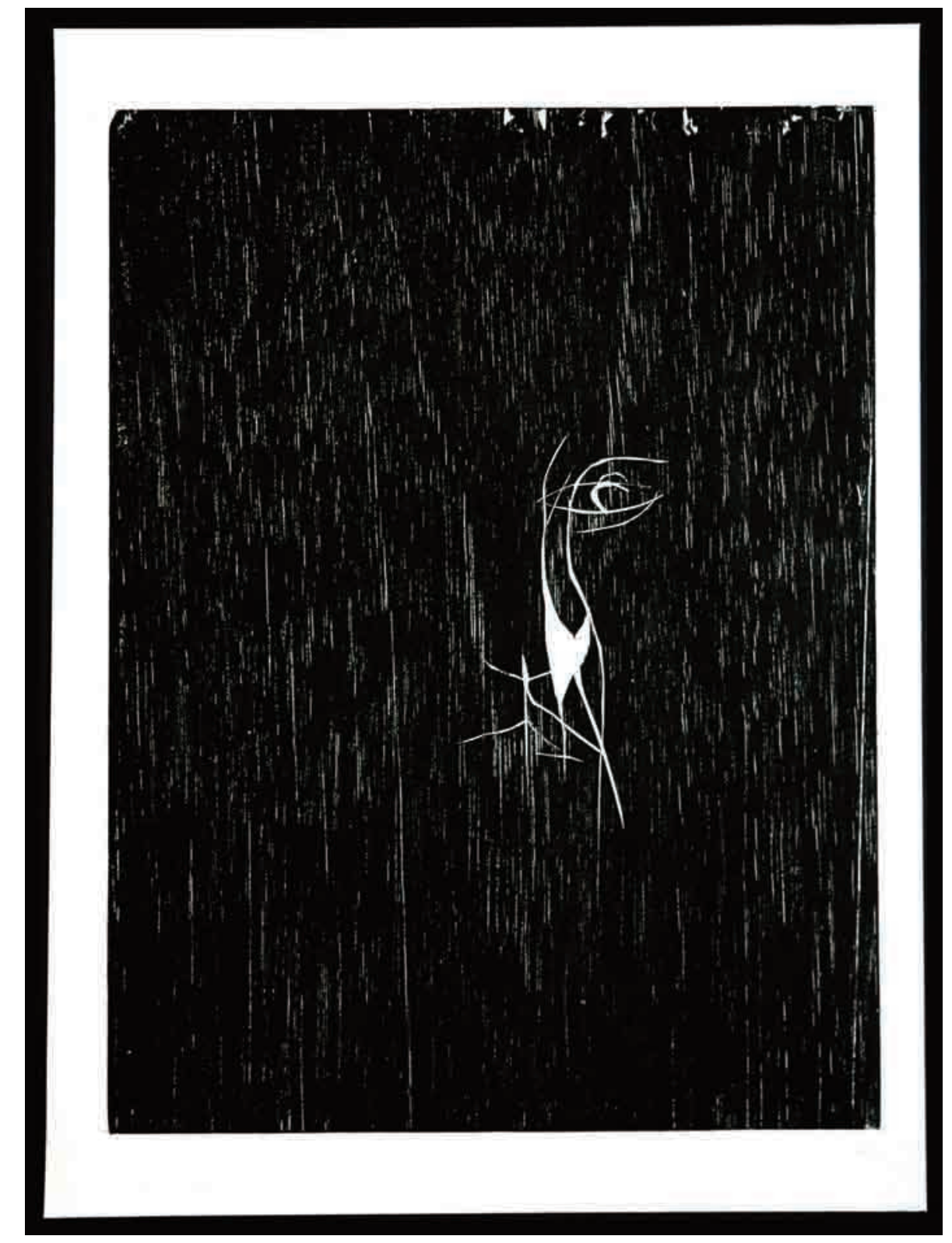


No "Retrato de Maria Helena" esta busca está presente nas gravações que resultaram na luz que se encontra no centro da face, e tange o nariz, os olhos e a boca. Após uma primeira gravação linear, cheguei a atual configuração através de tentativas de gravações e impressões em que abri esta luz, sendo que nas provas imprimi apenas esta parte da matriz, mesmo correndo o risco de perder a visão de sua totalidade, com uma certeza de ser este o foco. 


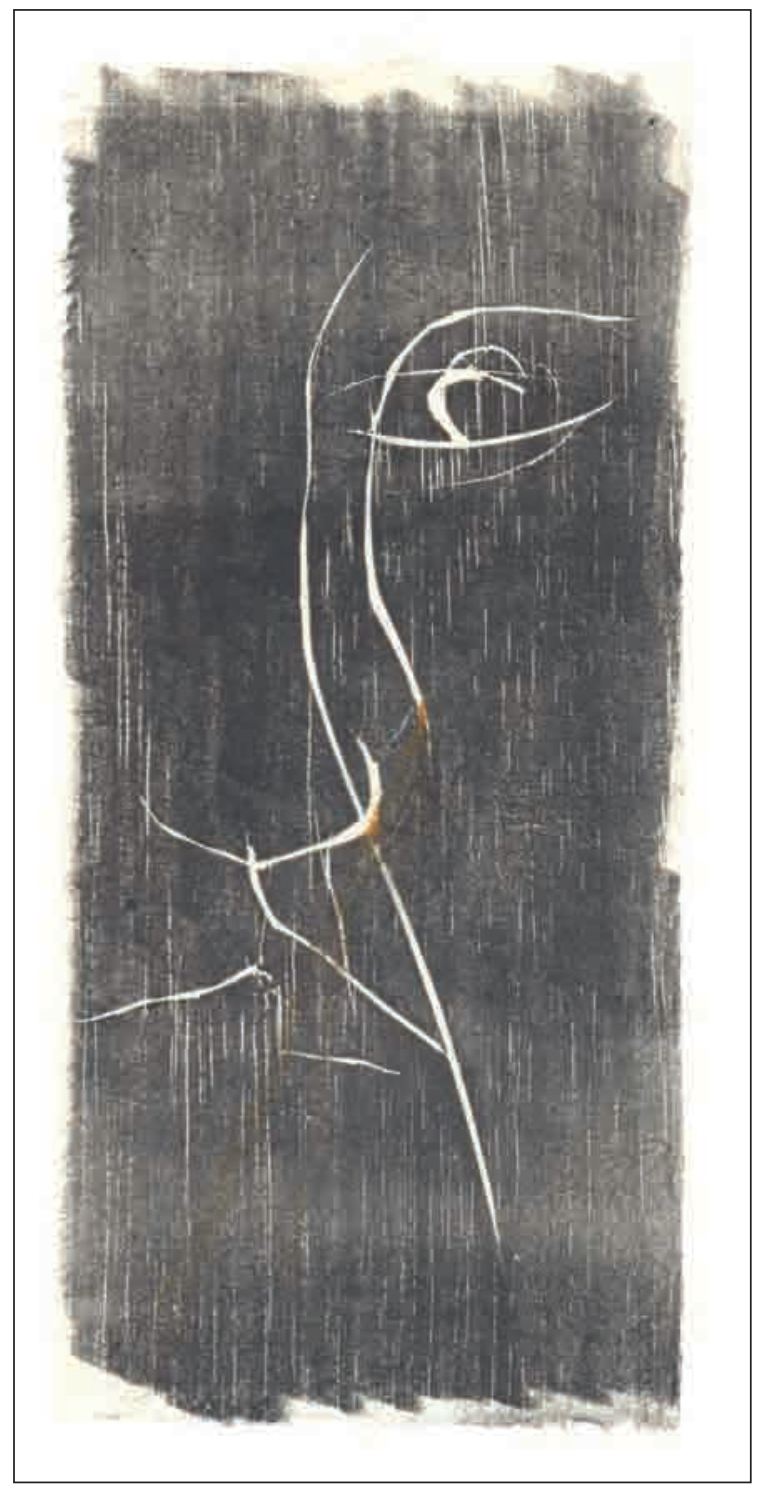

99. Retrato de Maria Helena, 2005

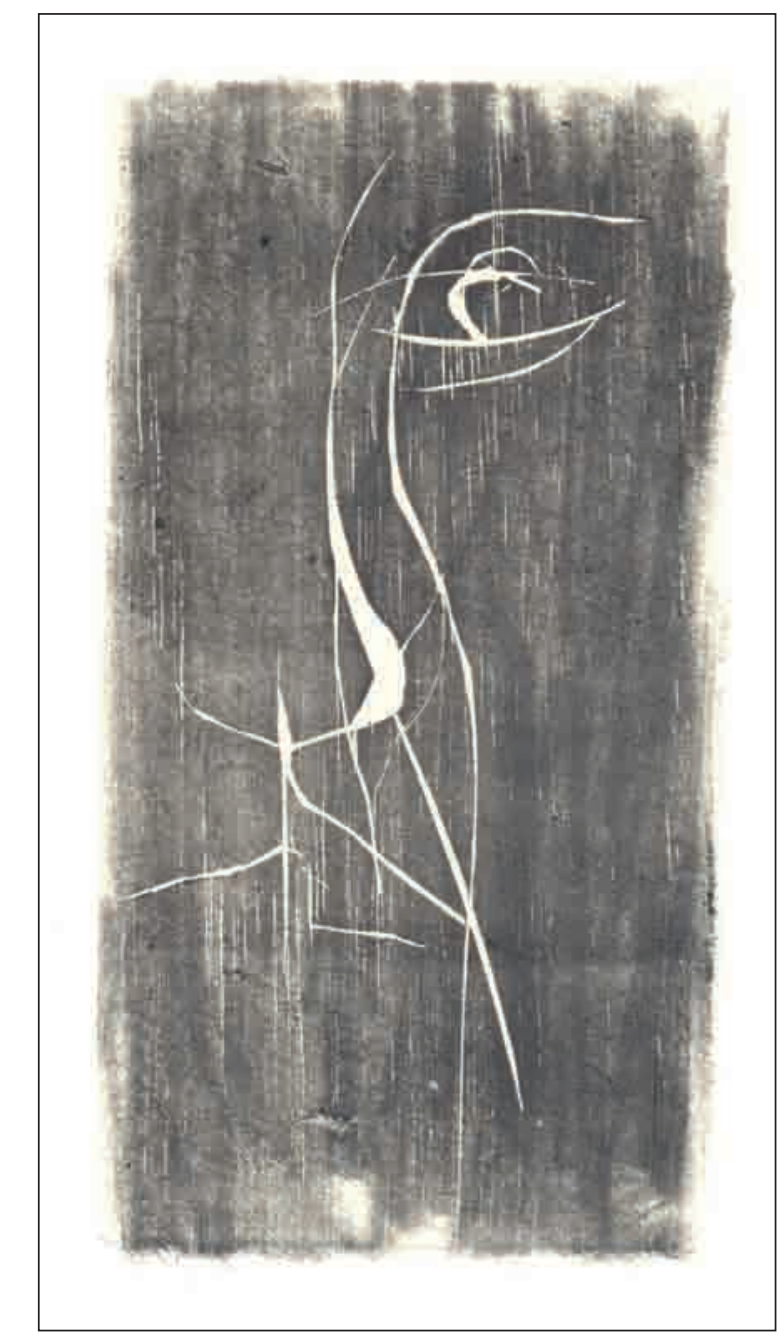

100. Retrato de Maria Helena, 2005

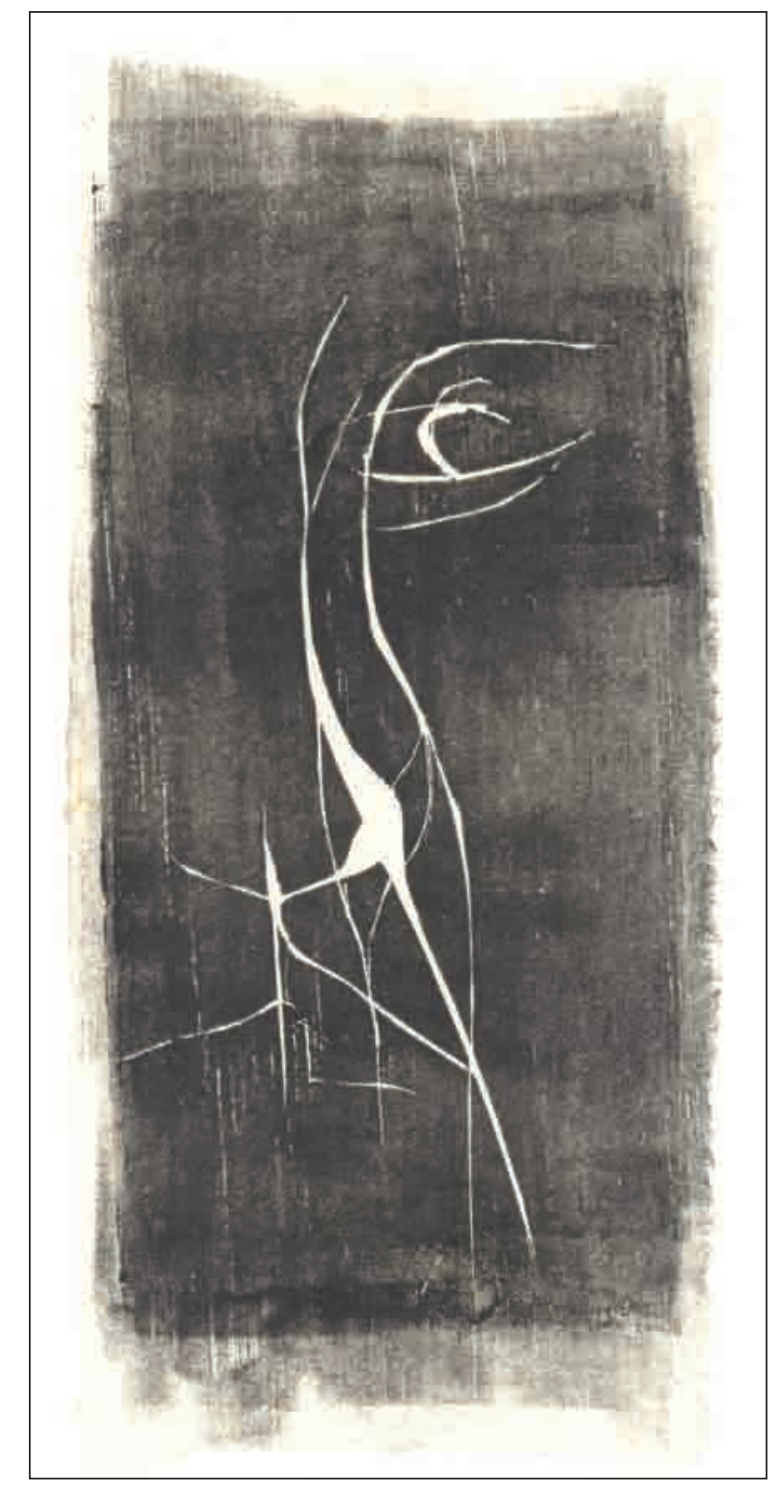

101. Retrato de Maria Helena, 2005 
No "Retrato Torção de Adalgisa", empreguei a colagem sobre uma prova como recurso do desenho para pensar sobre a luz que abri. Cheguei a esta configuração partindo de uma primeira estrutura linear em que havia indicações de uma figura de perfil e outra frontal, e a luz no centro me permitiu condensar estas vistas, sugerindo um movimento de torção da face, ao voltar-se para a frente ou para o lado. Em "Adalgisa de Perfil", das primeiras linhas segui a construção de um plano, que define o perfil, por meio do desbaste do entorno da massa que condensa a sua forma. 

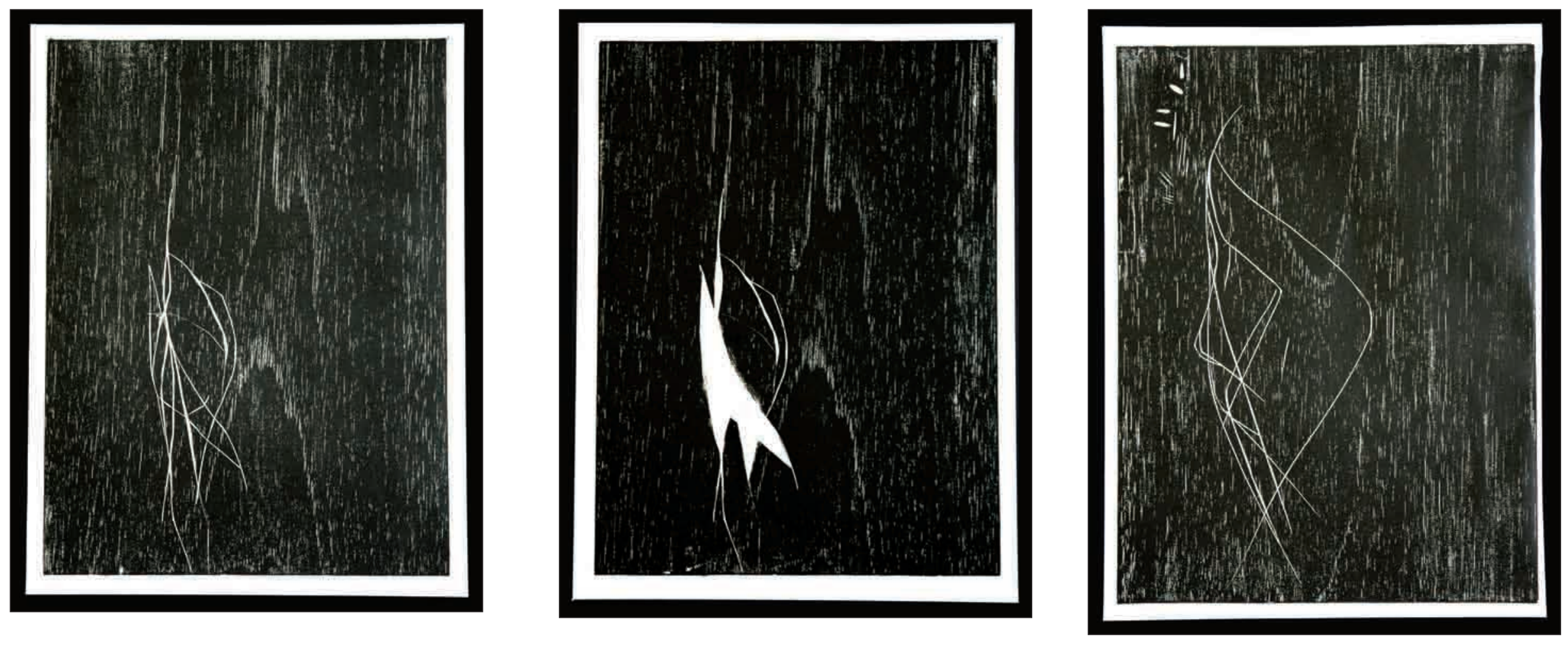
O desenho encontra no corte a economia de meios necessária para a sua construção, em que o retrato se manifesta na convergência e nas tensões entre luz e forma. 


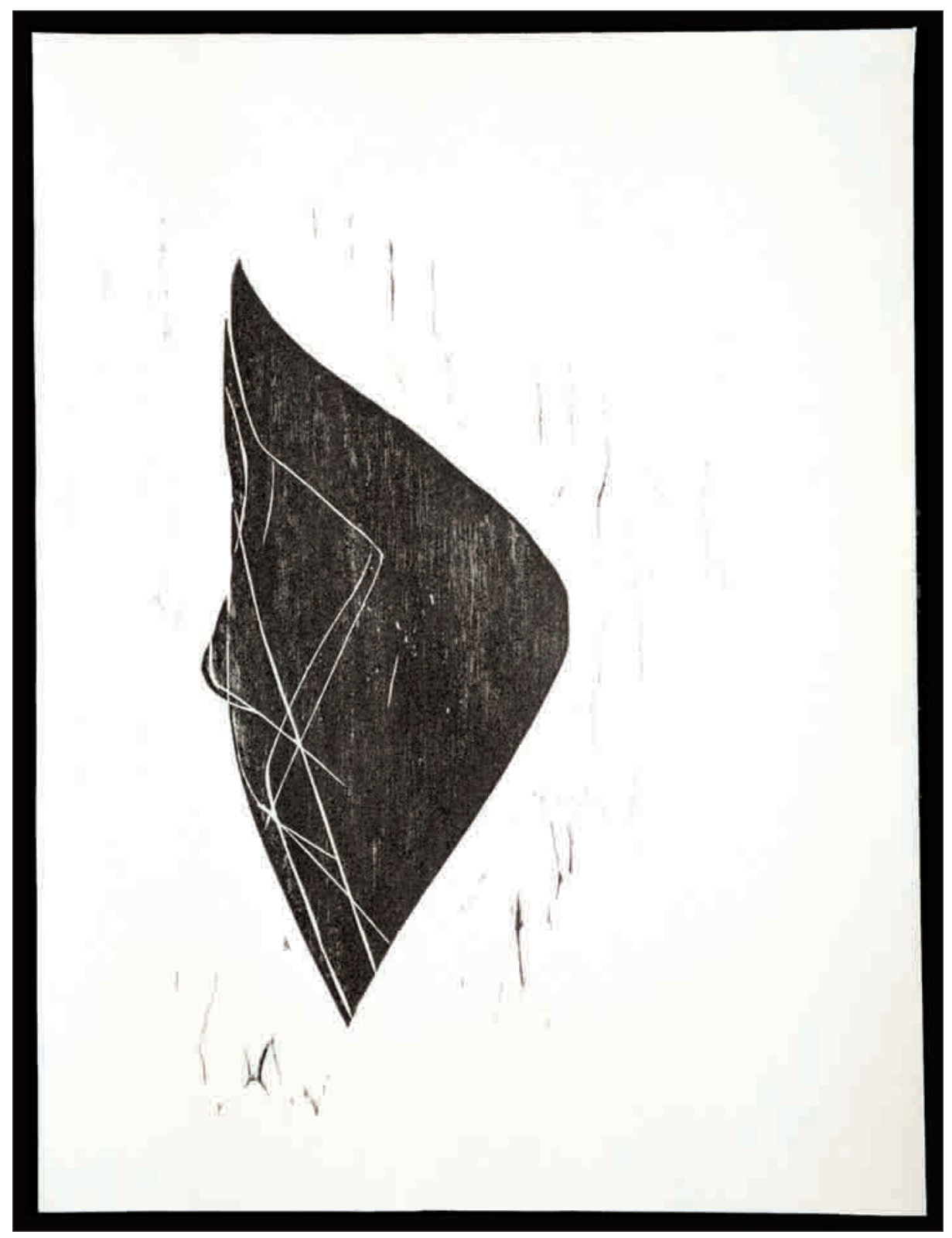

105. Adalgisa de Perfil, 2006 
Nestes retratos, o desenho se constitui no anseio e na busca deste encontro, em cada construção, e no movimento entre as manifestações, entre o desejo, observação e memória, em que cada manifestação possui sua própria concretude e se abre, ao guardar e evocar traços, e ao designar outros possíveis. Neste percurso, o retrato se constitui como presença, memória e devir, em cada construção figurativa e neste movimento entre as pessoas e suas figuras, que se atualizam e entrelaçam, abrindose a novas configurações. 


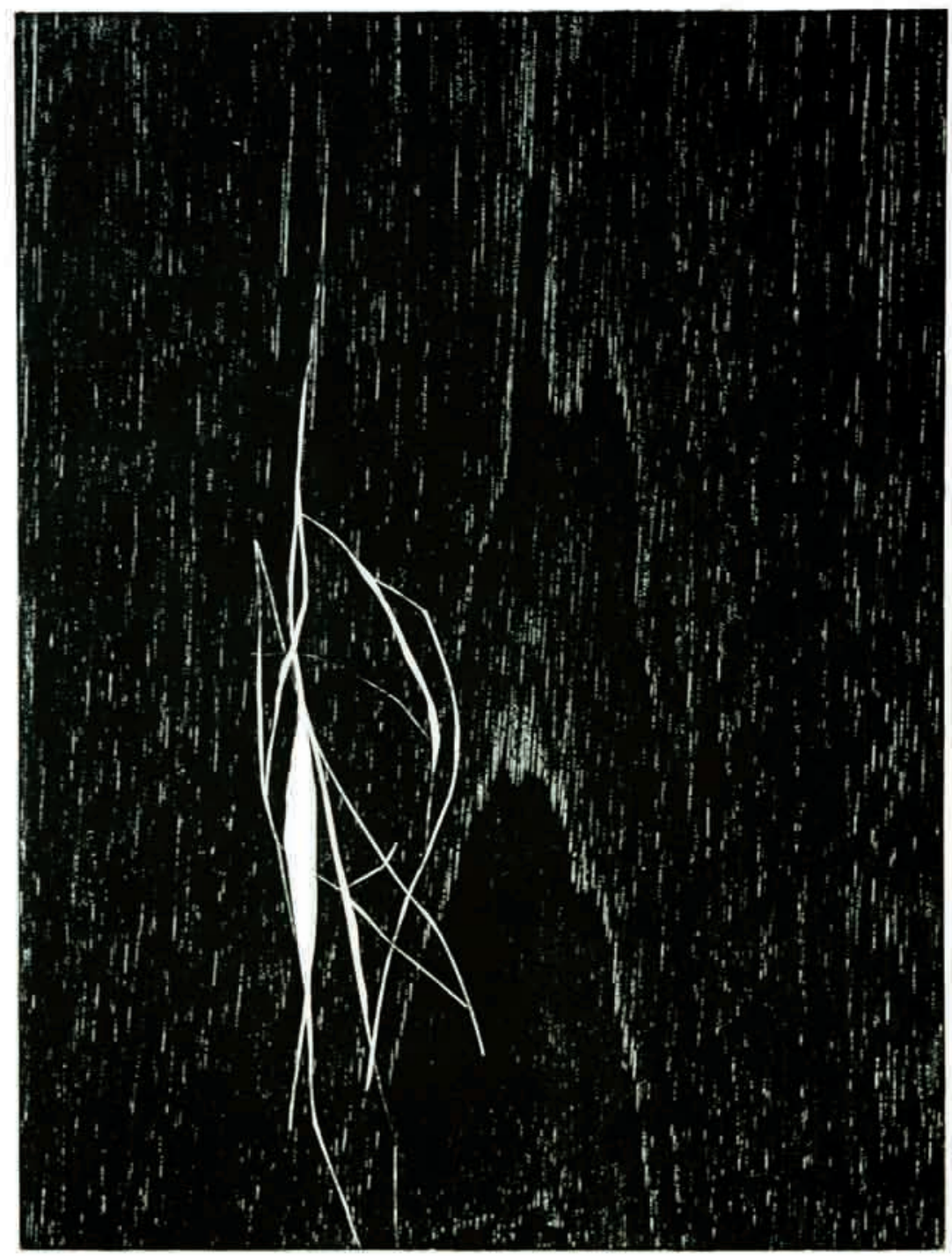




\section{Relação de obras:}

1. Sem Título, 2000

Sanguínea, 25 x $18 \mathrm{~cm}(\mathrm{~V} \times \mathrm{H})$

2. Sem Título, 2000

Sanguínea, 25 x $18 \mathrm{~cm}$

3. Sem Título, 1999

Guache, $28 \times 21 \mathrm{~cm}$

4. Sem Título, 1999

Guache, 28 × $21 \mathrm{~cm}$

5. Sem Título, 2001

Grafite, $21 \times 15 \mathrm{~cm}$

6. Sem Título, 2001

Grafite, 21 x $15 \mathrm{~cm}$

7. Figura Recolhida, 2005 Xilogravura, $170 \times 70 \mathrm{~cm}$

8. Figura Recolhida, 2000 Xilogravura, $170 \times 70 \mathrm{~cm}$

9. Figura Recolhida, 2000

Xilogravura, 170 x $70 \mathrm{~cm}$
10. Figura em Repouso, 2001

Xilogravura, $170 \times 70 \mathrm{~cm}$

11. Sem Título, 2005

Grafite e Pedra Negra, 175 × 30 cm

12. Sem Título, 2005

Grafite e Guache, 175 × $30 \mathrm{~cm}$

13. Sem Título, 2005

Pedra Negra, 175 x $60 \mathrm{~cm}$

14. Sem Título, 2005

Pedra Negra, 175 x $60 \mathrm{~cm}$

15. Sem Título, 2005

Carvão, 150 x 60 cm

16. Sem Título, 2005

Carvão, 150 x 60 cm

17. Figura Agachada, 2001 Xilogravura, 90 x $70 \mathrm{~cm}$

18. Sem Título, 2005

Carvão, 80 x $60 \mathrm{~cm}$

19. Figura Agachada, 2005 Xilogravura, 150 x $70 \mathrm{~cm}$

20. Duas Cabeças, 2001 Xilogravura, $90 \times 70 \mathrm{~cm}$

21. Duas Cabeças, 2004 Xilogravura, 90 x $70 \mathrm{~cm}$ 
22. Duas Cabeças, 2005 Xilogravura, 90 x $70 \mathrm{~cm}$

23. Figura Aberta, 2001

Xilogravura, 180 x $96 \mathrm{~cm}$

24. Figura Hierática, 2005 e

Figura Aberta, 2001

(impressões justapostas e aquareladas)

Xilogravura, 180 x $96 \mathrm{~cm}$

25. Figura Aberta, 2001

Xilogravura, 180 x $96 \mathrm{~cm}$

26. Linha Contínua Aberta, 2005

Xilogravura, 180 × $90 \mathrm{~cm}$

27. Núcleo Corda, 2006

Xilogravura, 175 x $96 \mathrm{~cm}$

28. Núcleo Corda, 2001

Xilogravura, 175 × $90 \mathrm{~cm}$

29 Núcleo Corda, 2001

Xilogravura, 175 x $96 \mathrm{~cm}$

30. Sem Título, 2006

Pedra Negra, 160 x $107 \mathrm{~cm}$

31. Sem Título, 2006

Pedra Negra, 170 x $107 \mathrm{~cm}$
32. Núcleo Corda, 2006

Xilogravura, 175 × $90 \mathrm{~cm}$

33. Núcleo Corda, 2006

Monotipia e Xilogravura, 175 x $90 \mathrm{~cm}$

34. Figura de Perfil, 2005

Xilogravura, 175 x $50 \mathrm{~cm}$

35. Figura de Perfil, 2004 Xilogravura, 175 x $90 \mathrm{~cm}$

36. Figura de Perfil, 2004 Xilogravura, 175 × $90 \mathrm{~cm}$

37. Figura Hierática, 2005 Xilogravura, 180 x $70 \mathrm{~cm}$

38. Sem Título, 2005

Carvão, 160 x 107 cm

39. Figura Hierática, 2005 Xilogravura, 180 x $70 \mathrm{~cm}$

40. Figura Sentada, 2005

Xilogravura, $180 \times 60 \mathrm{~cm}$

41. Sem Título, 2005

Carvão, 100 x 107 cm

42. Figura Sentada, 2005

Xilogravura, 180 x $70 \mathrm{~cm}$ 
43. Duas Figuras, 2002

Xilogravura, $175 \times 70 \mathrm{~cm}$

44. Duas Figuras, 2002 Xilogravura, 180 x $90 \mathrm{~cm}$

45. Duas Figuras, 2006

Xilogravura, 180 x $90 \mathrm{~cm}$

46. Sem Titulo, 2005

Grafite, 30 x $21 \mathrm{~cm}$

47. Sem Titulo, 2005

Grafite, 30 x $21 \mathrm{~cm}$

48. Sem Titulo, 2006

Grafite, 30 × $21 \mathrm{~cm}$

49. Sem Titulo, 2006

Grafite, 30 x $21 \mathrm{~cm}$

50. Sem Titulo, 2005

Ponta de Prata, $30 \times 21 \mathrm{~cm}$

51. Sem Titulo, 2005

Ponta de Prata , $30 \times 21 \mathrm{~cm}$

52. Sem Titulo, 2005

Grafite, 30 x $21 \mathrm{~cm}$

53. Sem Título, 2005

Grafite, $30 \times 21 \mathrm{~cm}$
54. Sem Titulo, 2005

Grafite, 30 x $21 \mathrm{~cm}$

55. Sem Titulo, 2006

Grafite e Pedra Negra, 30 × $21 \mathrm{~cm}$

56. Retrato de Adalgisa, 2005

Ponta Seca e Água Tinta 48 × $39 \mathrm{~cm}$

57. Retrato Lateral de Manoel, 2005 Ponta Seca 48 x $39 \mathrm{~cm}$

58. Retrato Frontal de Manoel, 2005 Ponta Seca 48 x $39 \mathrm{~cm}$

59. Retrato de Adalgisa, 2001

Ponta Seca 48 × $39 \mathrm{~cm}$

60. Retrato Lateral de Manoel, 2001 Ponta Seca 48 x $39 \mathrm{~cm}$

61. Retrato Frontal de Manoel, 2001 Ponta Seca 48 × $39 \mathrm{~cm}$

62. Retrato Frontal de Manoel, 2002 Ponta Seca e Água Tinta 48 × $39 \mathrm{~cm}$

63. Retrato Frontal de Manoel, 2002 Ponta Seca e Água Tinta 48 × 39 cm

64. Retrato Lateral de Manoel, 2002 Ponta Seca e Água Tinta 48 × $39 \mathrm{~cm}$ 
65. Retrato Lateral de Manoel, 2002 Ponta Seca e Água Tinta 48 × 39 cm

66. Retrato de Adalgisa, 2005

Ponta Seca e Água Tinta 48 × 39 cm

67. Retrato de Adalgisa, 2005

Ponta Seca e Água Tinta 48 × $39 \mathrm{~cm}$

68. Retrato de Adalgisa, 2005

Ponta Seca e Água Tinta 48 x 39 cm

69. Retrato de Adalgisa, 2005

Ponta Seca e Água Tinta 48 × 39 cm

70. Retrato Frontal de Manoel, 2005

Ponta Seca 52 × $41 \mathrm{~cm}$

71. Retrato Lateral de Manoel, 2005

Ponta Seca 52 x $41 \mathrm{~cm}$

72. Sem Título, 2005

Aquarela sobre Ponta Seca, 52 × $41 \mathrm{~cm}$

73. Sem Título, 2005

Óleo sobre Buril, 52 x $41 \mathrm{~cm}$

74. Sem Título, 2005

Monotipia sobre Água Tinta, 52 × $41 \mathrm{~cm}$

75. Sem Título, 2005

Monotipia sobre Buril, 52 x $41 \mathrm{~cm}$
76. Vulto, 2004

Água Tinta 48 × $39 \mathrm{~cm}$

77. Retrato de Adalgisa, 2005

Ponta Seca e Água Tinta 48 × 39 cm

78. Cabeça que Flutua, 2004

Buril e Água Tinta $48 \times 39 \mathrm{~cm}$

79. Cabeça que Flutua, 2004

Buril e Água Tinta 48 × $39 \mathrm{~cm}$

80. Sem Título, 2005

Pintura a Óleo sobre Água Tinta, 42 × $35 \mathrm{~cm}$

81. Retrato de Manoel, 2006

Ponta Seca e Água Tinta 48 × $39 \mathrm{~cm}$

82. Retrato de Adalgisa, 2006

Ponta Seca e Água Tinta 48 × 39 cm

83. Dois Retratos de Manoel, 2006

Ponta Seca, $42 \times 40 \mathrm{~cm}$

84. Dois Retratos de Manoel Lendo, 2006

Ponta Seca, $42 \times 40 \mathrm{~cm}$

85. Retrato Caligráfico de Adalgisa, 2006

Água Forte $31 \times 58 \mathrm{~cm}$

86. Retrato Trama de Maria Helena, 2006

Buril e Água Forte 52 × $41 \mathrm{~cm}$ 
87. Retrato Trama de Maria Helena, 2005 Buril $52 \times 41 \mathrm{~cm}$

88. Retrato Trama de Maria Helena, 2005 Buril e Água Forte 52 × $41 \mathrm{~cm}$

89. Retrato Trama de Manoel, 2006 Água Forte 52 x $41 \mathrm{~cm}$

90. Retrato Trama de Manoel, 2002 Água Forte 52 x $41 \mathrm{~cm}$

91. Retrato Trama de Manoel, 2006 Água Forte 52 x $41 \mathrm{~cm}$

92. Retrato Negro de Manoel, 2004 Água Forte e Ponta Seca 52 × $41 \mathrm{~cm}$

93. Retrato Negro de Manoel, 2004 Água Forte e Ponta Seca 52 × $41 \mathrm{~cm}$

94. Retrato Negro de Manoel, 2006 Água Forte e Ponta Seca 52 × $41 \mathrm{~cm}$

95. Retrato de Manoel, 2005

Xilogravura 40 × $32 \mathrm{~cm}$

96. Retrato de Adalgisa, 2005

Xilogravura 40 × $32 \mathrm{~cm}$

97. Retrato Oblíquo de Manoel, 2006 Xilogravura 40 × $32 \mathrm{~cm}$
98. Retrato de Maria Helena, 2005 Xilogravura 40 x $32 \mathrm{~cm}$

99. Retrato de Maria Helena, 2005 Xilogravura $13 \times 18 \mathrm{~cm}$

100. Retrato de Maria Helena, 2005 Xilogravura 13 x $18 \mathrm{~cm}$

101. Retrato de Maria Helena, 2005 Xilogravura 13 x $18 \mathrm{~cm}$

102. Retrato Torção de Adalgisa, 2006 Xilogravura 40 × $32 \mathrm{~cm}$

103. Retrato Torção de Adalgisa, 2006 Xilogravura e Colagem 40 × $32 \mathrm{~cm}$

104. Adalgisa de Perfil, 2006 Xilogravura 40 x $32 \mathrm{~cm}$

105. Adalgisa de Perfil, 2006 Xilogravura 40 × $32 \mathrm{~cm}$

106. Retrato Torção de Adalgisa, 2006 Xilogravura 40 × $32 \mathrm{~cm}$ 
ALBERTI, Leon Batista. Da Pintura. Campinas, Ed. Unicamp, 1999.

AUERBACH, Erich. Figura. São Paulo, Editora Ática, 1997.

BACHELARD, Gaston. A Poética do Espaço. São Paulo, Ed. Martins Fontes, 1996.

BARATA, Mario (org.) et alii. Mostra da Gravura Brasileira; Catálogo da Bienal Nacional 1974. São Paulo: Fundação Bienal, 1974.

BARTHES, Roland. A Câmara Clara. Rio de Janeiro, Ed Nova Fronteira, 1984. Trad. Júlio Castañon Guimarães.

BENEVOLO, Leonardo, ALBRECHT, Benno. Le Origini Dell'architetura. Roma, Editori Laterza, 2002.

BAXANDALL, Michael. O Olhar Renascente, Pintura e Experiência Social na Itália da Renascença. Rio de Janeiro, Paz e Terra, 1991.

BENJAMIN, Walter. Magia e técnica, arte e política: ensaios sobre literatura e história da cultura. São Paulo, Ed. Brasiliense, 1994. Trad. Sergio Paulo Rouanet.

BLUNT, Anthony. Teoria Artística na Itália 1450 - 1600. São Paulo, Cosac e Naify Ed. 2001.

BLUM, André. Les Primitifs de la Gravure sur Bois, Étude Historique et Catalogue des Incunabules Xylographiques du Musée du Louvre. Paris: Librarie Grundi, 1956. 
BOIS, Yve-Alain. Painting as Model. The MIT Press, 1990.

BRUNNER, Felix. A Handbook of Graphic Reproduction Processes. Stuttgart, Gerd Hartje, 1984.

BUTI, Marco, LETYCIA, Anna (organizadores). Gravura em Metal. São Paulo, Edusp: Imprensa Oficial do Estado, 2002.

CARREIRA, Eduardo. (organização, tradução e comentários). Estudos de Iconografia Medieval: O Caderno de Vuillard de Honnecourt, arquiteto do século XIII. Brasília, Editora Universidade de Brasília, 1997.

CASTLEMANN, Riva. Prints of the XX Century (revised and enlarged edition). Londres: Thames and Hudson, 1988.

CENNINNI, Cenninno. II libro dell'Arte o Tratatto della Pittura. Milano, Lognesi, 1975.

CHARDIN, Pierre Teillard de. O Fenômeno Humano. São Paulo, Cultrix, 1994.

CORDARO, Madalena Natsuko Hashimoto. Pintura e Escultura do Mundo Flutuante: Hishikawa Moronobu e Ukiyo-e - Saikaku Ihara e Ukiyo - Zôshi. São Paulo: Hedra, 2002.

DÜRER, Albrecht. Lettres et Écrits Théoriques, Traité de les Proportions. Paris, Hermann, 1964.

HIND, Arthur M. A History of Engraving and Etching; from the Century XV to the year 1914. New York, Dover Publications Inc. 1963.

-An Introduction to the History of the Woodcut. New York: Dover Publications Inc. 2 vol.

HOLANDA, Francisco de; Da Pintura Antiga. Lisboa, Casa da Moeda, 1983. 
IVINS Jr. W.M. Imagem Impressa y Conocimiento; analisis de la imagem pre fotografica. Barcelona: Gustavo Gilli, 1975.

KOSSOVITCH, Leon ; LAUDANNA, Mayra e RESENDE, Ricardo. Gravura Brasileira. São Paulo, Cosac e Naify / Itaú Cultural, 2000.

KRAUSS, Rosalind. O Fotográfico. Barcelona, Editorial Gustavo Gilli, 2002. Trad. Anne Marie Davée.

MACAMBIRA, Ivoty de Macedo Pereira. Evandro Carlos Jardim. São Paulo: Edusp, 1998.

MAXADO, Franklin. Cordel: xilogravura e ilustrações. Rio de Janeiro: Codecri, 1982.

MERLEAU-PONTY, Maurice. Fenomenologia da Percepção. São Paulo: Martins Fontes, 1999.

MUBARAC, Claudio. Notas Sobre Incisão, Tese de Doutorado em Poéticas Visuais apresentada à Escola de Comunicações e Artes da Universidade de São Paulo, 1998.

MUBARAC, Claudio. Claudio Mubarac. São Paulo, Editora da Universidade de São Paulo, 1996 -(Artistas da USP, 5).

MUBARAC, Cláudio (curadoria e organização). O desenho estampado, a obra gráfica de Evandro Carlos Jardim. Pinacoteca do Estado de São Paulo, 2005.

PANOFSKY, Erwin. Renascimento e Renascimentos na Arte Ocidental. Lisboa, Presença, 1981.

PÉREZ-ORAMAS, Luis. An Atlas of Drawings. The Museum of Modern Art, New York, 2006 
RICHTER, J.P. Leonardo, The Notebooks of Leonardo da Vinci. Dover, New York, 1970.

THÉOPHILE. Essai sur les divers Arts. Ed. Trad. Intr. L'Escalopier et Ghichard. Fac. Sim. 28.2310 Nogeut-le-Roi, 1977.

RIBEIRO, Noemi Silva. Oswaldo Goeldi: um auto retrato. Rio de Janeiro: Centro Cultural do Banco do Brasil, 1995.

VALÉRY, Paul. Degas Dança Desenho. São Paulo, Cosac \& Naify, 2003.

VASARI. Le Vite de' Piu Eccelenti Architetti, Pittori et Scltori Italiani. Florença, 1550. ed. G. Milanesi, Florença, 1878, 1881.

WORRINGER, Wilhem. Abstracción y Naturaleza. México, Fondo de Cultura, 1953

WEISS, Luise. Retratos Familiares : "In Memoriam ”. Tese de Doutorado, Escola de Comunicações e Artes da Universidade de São Paulo, 1998.

WESTHEIM, PAUL. El Grabado en Madera. Mexico D.F.: Fondo de Cultura Economica, 1992.

WYE, Deborah. Thinking Print: books to billboards, 1980-95. New York: The Museum of Modern Art, 1996. 
Dedico este trabalho a meus amigos e minha família.

Agradeço ao Ateliê Brasil - Oriente pelas fotografias $(7 ; 17 ; 22 ; 25 ; 26 ; 27 ; 34 ; 37 ; 42$; 45); a Maria Carolina Costa Coutinho pela revisão do texto; a Marco Buti pela orientação; a Adalgisa Campos pelo projeto gráfico e pelo constante apoio e a Antonio, pela nova luz em minha vida. 